\title{
Mecmûa-i İlâhiyât'ın MESTAP'a Göre Muhteva Tablosu
}

\author{
Arş. Gör. Sevgi Limon \\ Selçuk Üniversitesi, Eğitim Fakültesi \\ Türkçe ve Sosyal Bilimler Eğitimi Bölümü \\ sevgi.limon@selcuk.edu.tr
}

Öz

Birçok araştırmacı ve bilim insanının önemini vurguladığı birer kültür mirası niteliği taşıyan şiir mecmuaları, hâlen bir kısmı bilinmeyen şair ve şiirlerin ortaya çıkarılması ve değerlendirilmesi çalışmalarına katkı sağlaması açısından en önde gelen kaynaklardandır. Süleymaniye Kütüphanesi Mehmed Arif Mehmed Murad bölümü, 48 numaralı Mecmû́a-i İlâhiyât da bu kaynaklar arasında yer almaktadır. İçine aldığı şairlerin yaşadığı yüzyıllar ve şiirlerin imla özellikleri göz önüne alınarak 16. yüzyıl sonu veya 17. yüzyıl başlarında derlendiği tahmin edilen mecmuada tertip tarihi ve mürettiple ilgili bir bilgiye yer verilmemiştir. 86 varaktan oluşan mecmuada 34 şaire ait 135 şiir bulunmakta ve geneli bir tarikata mensup olan tasavvuf şairlerinin ilahi aşk, pişmanlık, dünya kayıtlarından ayrılmak, mürşide bağlanmak vd. konulardaki ilahilerini barındırmaktadır. Mecmû'a-i İlâhiyât'ın hem biçim hem içerik bakımından incelendiği ve MESTAP'a göre muhteva tablosunun hazırlandığı bu çalışmanın amacı, mecmua çalışmalarına ve MESTAP'a katkı sağlamaktır.

Anahtar Kelimeler: Mecmua, ilahi mecmuası, MESTAP, Mehmed Arif Mehmed Murad.

\section{Contents Table of Mecmûa-i İlâhiyât According to MESTAP}

\begin{abstract}
Poetry collections, which is a cultural heritage that emphasized the importance of many researchers and scientists, are among the leading sources in terms of revealing and evaluating poets and poems, some of which are still unknown. Mecmûa-i İlâhiyât numbered 48 at Süleymaniye Library Mehmed Arif Mehmed Murad department is take place among these sources. İ the collection, which is estimated, by considering the centuries lived by the poets included in the collection and spelling characteristics of poems, to be compiled at the end of the 16th century and at the beginning of the 17th century, there is no information about the compiler and compilation date. The collection, which consists of 86 leaf, contains 135 poems belonging to 34 poets and contains hynms on divine love, regret, leave world ties, connect to murshid etc. topics. The purpose of this study, in which the collection is examined in terms of both form and content and prepared according to MESTAP, is to contribute to collection studies and MESTAP.
\end{abstract}

Keywords: Collection, hymn collection, MESTAP, Mehmed Arif Mehmed Murad. 


\section{GíRiş}

Edebiyat ve bilim alanında birçok şair ve ilim insanı ile ilgili bilgilere ulaşılan, çeşitli bilgi, not ve şiirlerin ilk hâllerinin gün yüzüne çımasına yardımcı olan mecmualar, "genelde bir veya daha fazla yazar yahut şaire ait çeşitli şekil ve hacimlerdeki din̂ิ, din dışı nesir ya da şiirlerden oluşan derleme kitaplar" olarak tanımlanmaktadır (Uzun, 2003, C. 28, s. 265).

Mecmuaların şekil özellikleri ve tertibi belirli benzerlikler içerse de bunlar mürettibin isteğine göre şekillenmektedir. Bu anlamda mecmuaları diğer edebî türler gibi tek bir biçimle sınırlandıramayız. Bu eserler belli bir düzenle hazırlandığı gibi herhangi bir kalıba veya tasnife uymadan hazırlanmış da olabilir. Mecmualar hemen her alanda bilgiye rastlanabilen ve bu alanlara katkı sağlayacak nitelikte eserlerdir. ${ }^{1}$

Mecmualar konu, şekil ve amaç vb. kıstaslara göre sınıflandırılmaktadır: "Kaside mecmualar, gazel mecmuaları, tahmis-muhammes mecmuaları, kıta mecmualar gibi kategoriler, şiir mecmualarında nazım şekillerini merkeze alan sınıflandırmalardır. İ̧erdiği konu ve türe göre musiki mecmuaları, ilahî mecmuaları, dua mecmuaları, tarih mecmuaları, inşa mecmuaları gibi farklı tasnifler de yapilabilir" (Aydemir, 2013, s. 53).

Bu makaleye konu olan mecmua tür açısından "ilahi mecmuları" sınıfına dâhil olmaktadır.

"Mutasavoıf şairler tarafindan dinî ve ilahi fikirleri muhtevi olarak yazılan manzumeler" (Baltac1, 2011, s. 89) olarak tanımlanan ilahi², "dinî temlere bă̆l bir çeşit Âşı Edebiyatı nazım şeklidir. İlahinin kelime anlamı "Allah'a ait, Allah'a mahsus" demektir. Bu sebeple ilahilerde Allah sevgisi ve dinî temalar yer alır. Divan Edebiyatı'nin tevhid ve münacatlarma benzer. Dinî törenlerde dergâhlarda ă̆ır bir makamla söylenir" (Uzun, 1981, C. 4, s. 357).

İlâhi mecmuaları ise "şiirlerin tamamı veya büyük kısmı "ilâhi" türünde yazılan manzumelerden oluşan eserler" (Köksal, 2017, s. 332) olarak tanımlanmaktadır. Bu mecmualar genelde fazla hacimli olmayan, hem aruz hem hece vezniyle yazılmış ilahileri barındırabilen, öne çıkan bazı mutasavvıfların ilahilerine daha çok yer verilen ve bazılarında bestelendiği makamın kaydedilmesine karşın çoğunda bu özelliğin olmadığı derlemelerdir. (Köksal, 2017, s. 332)

Şiir mecmuaları hakkında yapılan çalışmaların sayıları günden güne artmaktadır. ${ }^{3}$ Ancak ilahi mecmuaları bu çalışmalar arasında çok az bir yere sahiptir. ${ }^{4}$ İlahi mecmualarının

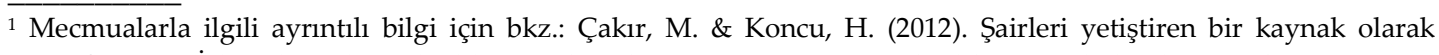
mecmûa. E. N. İşli (Ed.), Eski Türk edebiyatı çalışmaları VII, mecmûa: Osmanlı edebiyatının kırkambarı içinde (s. 117-134). İstanbul: Turkuaz Yay.; Gürbüz, M. (2013). Şiir mecmûalarının kaynakları üzerine. Turkish Studies, 8/1, 315-322. http://dx.doi.org/10.7827/TurkishStudies.4453; Köksal, M. F. (2012). Şiir mecmûalarının önemi ve mecmûaların sistematik tasnifi projesi (MESTAP). E. N. İşli (Ed.), Eski Türk edebiyatı çalı̧̧maları VII, mecmûa: Osmanlı edebiyatının kırkambarı içinde (s. 409-431). İstanbul: Turkuaz Yay.; Uzun, M. (2003). Mecmûa. Türkiye diyanet vakfi İslâm ansiklopedisi (C. 28, s. 265-268). Ankara: TDV Yayın Matbaacılık ve Ticaret İşletmesi; Aydemir, Y. (2007). Metin neşrinde mecmûaların rolü ve karşlaşlan problemler. Turkish Studies, 2/3, 122-137. http://dx.doi.org/10.7827/TurkishStudies.118.; Aydemir, Y. (2013). Mecmualara sorulması gereken sorular. Turkish Studies, 8/1, 51-64. http://dx.doi.org/10.7827/TurkishStudies.4633.

2 İlahilerle ilgili ayrıntılı bilgi için bkz.: Artun, E. (2017). Din̂t-tasavvufî halk edebiyatı. Adana: Karahan Kitabevi; Öztuna Y. (2000). İlâhî. Türk mûsikîsi kavram ve terimleri ansiklopedisi (s. 171-172). Ankara: Atatürk Kültür Merkezi Başkanlığı Yay.; Sözer, V. (2005). İlâhî. Müzik/ ansiklopedik sözlük (s. 361). İstanbul: Remzi Kitabevi.

3 Şiir mecmuaları hakkında yapılan çalışmalar için bkz.: Gıynaş, K. A. (2011). Şiir mecmuaları hakkında yapılan çalışmalar bibliyografyası. Selçuk Üniversitesi Edebiyat Fakültesi Dergisi, 25, 245-260. Erişim adresi: http://sefad.selcuk.edu.tr/sefad/article/view/97. Erişim tarihi: 15.03.2020; Tanyıldız, A. (2012). Şiir mecmualarının
} 
hem edebiyat ve dil hem de tarih açısından önemi göz ardı edilemez. Bu sebeple söz konusu eserlerle ilgili çalışmaların arttırılması sosyal bilimler adına önem arz etmektedir.

Bu makalede Süleymaniye Kütüphanesi Mehmed Arif Mehmed Murad bölümü, 48 numaralı Mecmû'a-i İlâhiyât şekil ve muhteva bakımından incelenmiştir. Bu mecmuanın konu olarak seçilmesindeki amaç ilahi mecmualarının mecmualar arasındaki değerini ortaya koyarak Mecmuaların Sistematik Tasnifi Projesi (MESTAP)'ne ${ }^{5}$ uygun şekilde mecmuanın dökümanını çıkarmak ve ilgili çalışmalara katkı sağlamaktır.

Çalı̧̧manın yöntemi Mecmuaların Sistematik Tasnifi Projesi (MESTAP)'ne göre şekillenmiştir. Bu bağlamda mecmuadaki ilahiler ayrıntılı bir muhteva tablosuyla aktarılmaya çalışılmıştır. Tablo hazırlanırken dikkat çeken ve tabloya alınamayan hususlara Mecmû‘a-i İlâhiyât'ın Şekil Bakımından Tanıtımı ve Mecmû‘a-i İlâhiyât'ın Muhtevası başlıkları altında ayrıntılı olarak yer verilmiştir.

\section{MECMÛ‘A-İ ILLÂHIYŶT'IN ŞEKIL BAKIMINDAN TANITIMI}

\section{1. Tavsifi ve Tertibi}

Süleymaniye Kütüphanesi Mehmed Arif Mehmed Murad bölümü, 48 numaralı Mecmû'a-i İlâhiyât, yazmanın vikaye varağında "Mecmû'a-i İlâhiyât Li-ba'żi'l 'Ârifîn" şeklinde adlandırılmıştır. Yine bu varakta sonradan yazıldığı anlaşılan "İlâhîler Mecmû'ası" ibaresi yer almaktadır.

Mecmuanın varak numaralarının farklı bir mürekkeple yazılması, numaraların sonradan verildiğini düşündürmektedir. İlk varakta bulunan "78 varaktır" kaydının da yine sonradan yazıldığı ve son varak numarasına bakılarak kaydedildiği görülmektedir. Ancak mecmua 86 varaktır ve çobanlardan(reddâde) anlaşıldığına göre varak eksikliği de yoktur. Yazmadaki kayıtla varak sayısı bakımından bu uyumsuzluk varak numaralandırılması esnasındaki hatadan kaynaklanmaktadır. Şöyle ki; mecmuada önceden verilen aynı numara sonraki bir varakta tekrar verilmiş ve o numara devam ettirilmiştir. Bundan dolayı sekiz varaklık bir kayma meydana gelmiştir. Çalışmada varak sayısının doğru verilebilmesi için

neşri hakkında. Uluslararası Sosyal Araştırmalar Dergisi, 5/21, 224-239. Erişim adresi: https://www.academia.edu/26982802/Şï̈_MECMÛALARININ_NEŞRİHAKKINDA. Erişim tarihi: 15.03.2020

Mecmualarla ilgili hazırlanan güncel tezler için bkz.: https://tez.yok.gov.tr/UlusalTezMerkezi/.

Mecmualarla ilgili yapılan çalışmalar için ayrıcı bkz.: https://www.osmanliedebiyati.com; https://mestap.com.

4 İlahi mecmualarıla ilgili tespit edilen ve online ortamdan erişilebilen on iki tez, iki makale ve bir bildiri bulunmaktadır;

Bildiri: Köksal, M. F. (2017). Dinî-tasavvufî Türk musikîsi araştırmalarında ihmal edilen bir yazma türü: ilâhî mecmuaları ve mühim bir ilâhi mecmuası. Ş. Özdemir \& A. Gün (Ed.), Geçmişten Günümüze Uluslararası Dinî Mûsikî Sempozyumu içinde (s. 331-336). Ankara: Kibatek.

Makaleler: Gürbüz, M. (2019). Konya Büyükşehir Belediyesi Koyunoğlu Müzesi ve Kütüphanesi'ndeki 13229 numaralı ilahi ve dua mecmuası. Akademik Dil ve Edebiyat Dergisi, 3/4, 179-220. https://doi.org/10.34083/akaded.656025.

Ciğa, Ö. (2016). Mevlâna Müzesi Kütüphanesinde kayıtlı 1626 numaralı ilâhî mecmûası. Dicle Üniversitesi Sosyal Bilimler Enstitüsü Dergisi, 17, 85-102. Erişim adresi: http://www.edusbed.com/Dusbed/ArchiveIssues/PDF/3960263b-6868-e711-80f0-00224d68272d. Erişim tarihi: 15.03.2020.

Tezler: tez künyeleri bkz. https://tez.yok.gov.tr/UlusalTezMerkezi

${ }^{5}$ Mecmuaların Sistematik Tasnifi Projesi Mehmet Fatih Köksal'ın başlattığ 1 ve Eski Türk Edebiyatıyla ilgili araştırma yapan öğrencilerden akademisyenlere kadar birçok kişi tarafından desteklenen bir projedir. "Projenin hedefi, öncelikli olarak şiir mecmuaları, nihâ̂ olarak da edebiyatla ilgili -cönkler de dâhil olmak üzere- bütün mecmûaların ayrnntılı tasnif ve dökümlerinin yapılmasıdır. Proje, katılmayı kabul ve taahhüt eden Eski Türk Edebiyatı alanı çalışmalarının lisansüstü tercihen yüksek lisans- öğrencilerine yaptırllacak tezler hâlinde yürütülecektir" (Köksal, 2012a, s. 422). Projenin web sitesi: https://mestap.com/.

SEFAD, 2020; (44): 213-250 
1b'den 86a'ya kadar yeniden bir numaralandırma yapılmıştır. Makalede varak numarası gösterilen yerlerde ise Fatih Köksal'ın önerisine uyularak mecmuadaki hatalı numaralandırma esas alınmıştır: "...varak numarası verilen (ki çoğunlukla öyledir) nüshalarda kitap üzerindeki numaralara sadık kalınmalıdır. Nadir de olsa aynı numara mükerreren yazılabilir (meselâ art arda gelen iki sayfada da 21 numarası yazması gibi) ya da tam tersi olarak numaralandırlmamış varaklar bulunabilir. Bu durum bir dipnotla belirtilmeli ve yanlış da olsa nüshadaki numaralara uyulmalıdır." (Köksal, 2012, s. 202/ 12. dipnot).

Mecmuanın kapağında yıpranma olmasına karşın varaklarda yıpranma bulunmamaktadır. Ebatları 207 x 137 - bb x bb mm olarak kaydedilen mecmuanın başlıklar dâhil ilk dokuz varağındaki satır sayısı on yedi, buradan son varağına kadarki sayfalarda ise satır sayısı on üçtür. İlk varakta vakıf bilgisini içeren bir mühür [Vaḳafe hâzé'l kitâb EsSeyyid Ḥâfız Meḥmed Murad Şeyh-i Ḩânḳ̂h-ı Murâd Molla (Bu kitabı Murad Molla Hangahı'nı şeyhi Seyyid Hafız Mehmed Murad vakfetti).] ve her varağında çoban(reddâde) bulunmaktadır.

On üçüncü varağa kadar kimi sayfalarda çift kimi sayfalarda da tek kırmızı cetvelli yazmanın sonraki sayfalarında cetvel kullanılmamıştır. Şiirlerin de bazıları çift sütun hâlinde beytin ilk mısraı sağda ikinci mısraı solda olacak şekilde yazılırken bazıları tek sütunda alt alta yazılmıştır. Başlıkların tamamı surhtur. Bu başlıklarda şairlerin mahlasıyla birlikte şairleri nitelemek veya ölmüş olanlarını anmak için bazı Arapça ifadelere de yer verilmiştir (Kuddise Sırruhu, Ravvaḥallāhu Rūḥahu vd.). Aynı şairin birden çok şiiri art arda geldiğinde ilk şiirinde başlık olarak mahlası kullanılmış sonraki şiirlere ise "velehü eyżan" başlı̆̆ verilmiştir. Şiirlerin tamamı ve harekeler siyah mürekkeple yazılmıştır. Birçok yazmada görülen mahlasların üzerine çizgi çekilerek vurgulanması şeklindeki uygulama bu mecmuada görülmemektedir.

Genel itibariyle okunaklı bir yazıya sahip olan ve şiirlerin harekeli nestalik yazı tipiyle yazıldığı mecmuada derkenarlar da bulunmaktadır. Bu kısımlardaki şiirler harekesiz olarak ve farklı bir yazı tipiyle yazılmıştır. Bunların bir kısmı özensiz ve silik olduğu için bazı kelime ve ibareler okunamamıştır.

Mecmuada hamdele, salvele, mukaddime, sebeb-i telif ve fihrist bulunmamaktadir. Mecmuanın ilk varağında Kaygusuz Vizeli Alaaddin'e ait;

Evliyāya egri bakmañ kevn ü mekān elindedür

Mülke hü̈kmin süren oldur iki cihān elindedür (Ekinci, 2013, s. 166; Gölpınarlı, 1932, s. 63).

matlalı bir şiir ve bazı Arapça ifadeler, son varağında ise Derviş mahlasıyla;

Eger zāhid sorar-iseñ bize ḳadrüñ cevābını

Ḥaḳị̣at ḳadre irendür aça gönül kitābını

matlalı bir şiir yer almaktadır. Ancak Gölpınarlı (1932) bu şiiri Kaygusuz Vizeli Alaaddin adlı kitabında yayınlamıştır (s. 50). Bunlar mecmuanın muhtevasına ait 
olmadıkları ${ }^{6}$ için MESTAP tablosuna dâhil edilmemiş fakat tablo kısmında dipnotlarda verilmiştir.

Şiir mecmuaları için farklı kıstaslar göz önüne alınarak çeşitli sınıflandırmalar yapılmıştır. Makalenin konusu olan mecmua Levend'in (1984) tasnifine göre, "aynı konudaki eserlerin bir araya getirilmesiyle meydana gelmiş mecmualar" (C. 1, s.166) sınıfına girmektedir. Zira ilahiler mecmuası olan bu eserde Allah'ın varlığı, birliği, yücelik ve kudreti, dünya kayıtlarından ayrılmak, mürşide bağlanmak gibi tasavvufi konular işlenmektedir.

Kılıç'ın (2012) tasnifine göre; şekil bakımından "ilahi mecmuarı" 7(s. 85), cilt ve tertip hususiyetlerine göre "mürettep mecmualar" (s. 81), mürettip durumuna göre "mürettibi bilinmeyen mecmualar" (s. 82), dil bakımından "Türkçe mecmualar" (s. 92), muhteva bakımından "tasavouf mecmuaları" (s. 93) sınıfına dâhil olmaktadır.

Gürbüz'ün (2012) sınıflandırmasında ise "şiirlerin konularına göre oluşturulan (tematik) şiir mecmuaları" (s. 109) sınıfına alınabilir.

Mecmû'a-i İlâhiyât, adlandırmadan da anlaşılacağı üzere -birkaç şiir hariç şiirlerin tamamı ilahi türünde olduğundan- nazım türü esas alınarak tertip edilmiştir. Fakat nazım türüne göre tertip ve tasnifi netleştirilse de şekil açısından mutlak bir tertip hususiyetinden söz etmek mümkün değildir. Zira mecmuadaki ilahilerin büyük bir bölümü gazel nazım şekliyle yazılmış olmasına karşın kaside, müfred, terci-i bend, murabba, muaşşer, mesnevi ve koşmaya da yer verilmiş ve bunlar herhangi bir düzen içinde mecmuaya alınmamıştır.

Mecmua Cemâl-i Halvetî'nin ilahisiyle başlamış sonra Âşık'in ve Yûnus'un daha sonra tekrar Cemâl-i Halvetî'nin ilahisiyle devam etmiştir. Bu duruma mecmuanın diğer bölümlerinde de rastlanmakta bu nedenle mürettibin mecmuayı şairlere göre de tasnif etmediği görülmektedir. Bütün bu hususlardan hareketle mürettibin mecmuayı; şair, vezin, kafiye/redif ve nazım şekli gibi herhangi bir tertip ölçütüne bağlı kalmadan sadece türü kıstas alarak tertip ettiği anlaşılmaktadır.

Fatih Köksal ilahi mecmualarının özelliklerini açılarken fazla hacimli olmamaları, hem hece hem aruzla yazılan şiirleri barındırmaları, belli başlı mutasavvıfların şiirlerinin sayıca diğer şairlerinkine göre çok önde oluşu ve bazılarında bestelendiği makamın kaydedilmesine rağmen çoğunda bu özelliğin olmaması gibi genelgeçer hususları sıralamaktadır (Köksal, 2017, s. 332) Ayrıca diğer ilahi mecmuası çalışmalarına ${ }^{8}$ bakıldığında çoğu mecmuanın tezhip bakımından sade olduğu, mürettibinin ve tertip tarihinin belli olmadığı, dini-tasavvufi konuları işlediği ve öğüt vermeyi amaçladığı görülmektedir. Buna göre ele alınan mecmuanın diğer mecmualarla ve Köksal'ın ölçütleriyle karşılaştıııldığında ilahi mecmualarının genel formuna büyük ölçüde uyduğu söylenebilir. Ancak bu mecmuayı diğer ilahi mecmualarından ayıran en önemli özellik hacimli olmasıdır. Zira ortalama 20-40 varak civarında olan ilahi mecmualarına karşın bu mecmua 86 varaktan oluşmaktadır.

\footnotetext{
${ }^{6}$ Yazı biçimi, mecmuadaki şiirlerin tamamında başlık bulunmasına rağmen bu şiirlerde olmayışı ve son varaktaki şiirin temmetten sonra yer alışı söz konusu şiirlerin mecmuaya sonradan eklendiğini, asıl içeriğe dâhil olmadıklarını göstermektedir.

${ }^{7}$ Kılıç'ın ilahileri şekil olarak sınıflandırmasına karşın Köksal "ilahi bir nazım şekli değil nazım türüdür." şeklinde bir açıklama yapmaktadır (Köksal, 2017, s. 331). Yine Yaşar Aydemir de ilahi mecmualarını türlere göre yaptığı sınıflandırmaya almıştır (Aydemir, 2013, s. 53). Bu çalışmada ilahi bir tür olarak kabul edilmiş ve MESTAP tablosunda şiirlerin nazım türü bölümüne "ilahi", nazım şekli bölümüneyse "gazel, kaside, koşma, murabba vd." yazılmıştır.

${ }^{8} \mathrm{Bu}$ çalışmalara giriş bölümünde değinilmiştir.
}

SEFAD, 2020; (44): 213-250 


\section{2. Mürettip ve Tertip Tarihi}

Mecmuada mürettip ve tertip tarihi ile ilgili bir kayıt bulunmamaktadır. Ancak $1 \mathrm{~b}$ 'de vakfiye mührü bulunmakta ve $2 a$ 'da da bir vakfiye notu yer almaktadır. Vakfiye notunda "Vaḳafe hâzée'l kitâb Es-Seyyid Ḥâfız Meḥmed Murad Şeyh-i Hnânkâh-ı Murâd Molla (Bu kitabı Murad Molla Hangahı'nın şeyhi Seyyid Hafız Mehmed Murad vakfetti)." yazmaktadır. Buna göre yazmanın sahibinin Murad Molla Tekkesi ve Kütüphanesinin banisi Murad Molla lakabıyla tanınan Kazasker Damadzâde Mehmed Murad olduğu söylenebilir. Damadzâde Mehmed Murad kendi ismiyle 1183'te (1769) bir tekke ve 1189'da (1775) bir kütüphane kurmuştur. Bu kütüphanedeki yazmaların bir kısmı 1949-1954 yıllarında Süleymaniye Kütüphanesi'ne taşınmış son olarak 1999 depreminde kütüphanenin iyice hasar görmesiyle kalan koleksiyon da Süleymaniye Kütüphanesi'ne alınmıştır (Erünsal, 2006, C. 31, s. 188; Özdil, 2014). Söz konusu mecmua da bu koleksiyonda bulunan yazmalardan biridir. "Mehmed Arif Mehmed Murad" koleksiyon adındaki Mehmed Arif ise Mehmed Murad'ın oğlu ve Murad Molla Kütüphanesi'nin mütevellisidir.

Mecmuanın mürettibi belli olmasa da son varakta bulunan ve katibe dua talebinde bulunulan aşağıdaki beytin mürettibe ait olduğunu düşünüyoruz:

Hुayra yazsun şerrini anuñ Kirāmen kātibīn

Her kim añarsa du'ādan işbu ḩațtuñ kātibin

Yine aynı varakta bulunan "temmet" kaydıyla mürettibin mecmuayı tamamladığını ifade etmesi dikkat çekmektedir. Ayrıca bazı sayfalarda farklı yazı stiliyle yazılmış derkenar şeklinde şiir ve fevaid addedebilecek notlar bulunmaktadır. Buna göre mecmua derkenarlar hariç tek elden çıkmıştır, denebilir.

Mecmuada kimliği tespit edilen şairlere göre 14, 15 ve 16. yüzyıllara ait şiirler bulunmaktadır. Buna göre mecmua büyük ihtimalle 16. yüzyılın sonları veya 17. yüzyılın başlarında derlenmiştir. Ancak gerek kimliği tespit edilemeyen şairler gerekse cilt, kâğıt tipi ve bazı imla özellikleri göz önüne alındığında mecmuanın bu tarihlerden sonra da tertip edilmiş olması muhtemeldir.

\section{4. Derleniş Amacı}

Şiir mecmualarının çoğu mürettibinin kendi zevk ve isteğine göre derlenmiştir. Gürbüz (2012) mecmuaların derlenme sebeplerini iki grupta toplamaktadır: "kişisel sebepler, toplumsal sebepler" (s.1).

Çakır ve Koncu'nun (2012) dikkat çektikleri üzere ise mecmualar öğretici/ bilgilendirici bir rol üstlenebilmektedirler. Bu kıstasa göre şu sınıflandırma yapılmıştır: "Sadece şairlere yönelik bilgi verme gayreti, genel okuyucuya yönelik bilgi verme gayreti, mecmua tertipçisinin kendisi için aldı̆̆ı notlar" (s. 120).

$\mathrm{Bu}$ değerlendirmeler göz önüne alındığında Mecmû'a-i İlâhiyât'ın rastgele derlenmediğini özel bir amaçla oluşturulduğunu söyleyebiliriz. Zira mecmuadaki ilahiler Gürbüz'ün (2012, s. 1) belirttiği gibi belli bir alana/konuya odaklanmış, Allah'ın varlığını, birliğini, tasavvuf neşvesini okuyucuya aktarma ve öğüt vererek onları yönlendirme görevini amaç edinmiştir. Bu itibarla ele alınan mecmuayı "kişisel sebepler"den ziyade "toplumsal sebepler"le yazılmış bir mecmua olarak addetmek gerekir. Çakır ve Koncu'nun (2012, s. 120) tasnifine göre ise "genel okuyucuya yönelik bilgi verme" sınıfına dâhil edilebilecek 
Mecmû́a-i İlâhiyât'ın oldukça sade ve akıcı dil özellikleri de dikkate alındığında amacının genel bir okuyucu kitlesine seslenip onlara yol göstermek olduğu daha iyi anlaşılmaktadır.

\section{5. İmla Özellikleri}

İncelenen mecmuada hâkim olan dil Türkçedir. Ancak az da olsa Arapça ve Farsça şiirler de vardır (20a, 28b, 37b, 56a, 60a, 71b, 77b). Farklı dönemlerde yaşamış şairlerin şiirlerinin alındığı mecmuaya Eski Anadolu Türkçesi, Eski Osmanlı Türkçesi ve Klasik Osmanlı Türkçesi yazım özelliklerinin hâkim olduğ $\mathrm{u}^{9}$ öne sürülebilir.

Şiirlerin harekeli yazılmış olması özellikle fonetik hususların tespitine ve örneklenmesine yardımcı olmaktadır.

Divanlar ve diğer kaynaklarla karşılaştırıldığında mürettibin mecmuaya aldığı şiirlerde bu kaynaklardaki imla özelliklerini büyük ölçüde koruduğu söylenebilir.

Mecmuada tespit edilen bazı imla özellikleri şunlardır: ${ }^{10}$

1) Mecmuaya alınan çoğu şiirde Eski Anadolu Türkçesi yazım özellikleri hâkimdir:

" كوردوكى " gördügi (63b/9), " انكله " anuñla(45b/11),

" اتمشمدر " itmişemdür (15b/2), " بلورسن " bilürsin (53a/10) vb.

2) Mecmuada Eski Anadolu Türkçesinde yoğun kullanılan fakat günümüzde arkaik olmuş veya değişime uğramış pek çok ek, kelime ve gramer yapıları bulunmaktadır:

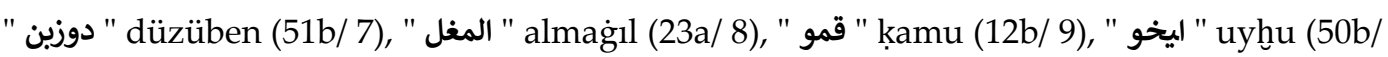
1), اليخده" ayahda (38b/6) vb.

3) Terkiplerdeki izafet "i"si "kesre" ile, atıf "vav" ları hem "و, vav" hem "ötre" ile gösterilmektedir:

a)

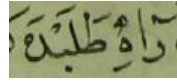

b)

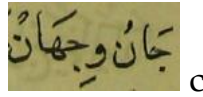

rāh-1 țalebde (6a/ 15)

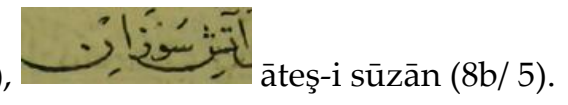

cān u cihān (17a/ 12),

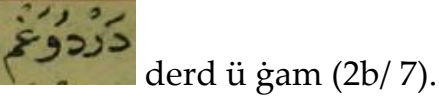

4) Kelime ortasında hemze bulunan Arapça kelimelerde hemze yerine " $"$ " harfi kullanılmıştır:

" dāyim (3b/4), " كايناتك " kāyinātuñ (67b/5).

Genel anlamda düzenli denebilecek mecmuada bazı yazım hataları veya bir yapının birden fazla imlasıyla kullanıldığı görülmektedir. Bunlar mürettibin veya müstensihin yazıya aktarırken yaptığı hatadan ötürü olabileceği gibi şiirin alındığı kaynaktaki hatanın aynen alınmasından da kaynaklanabilir:

1) Mecmuadaki "ben" zamirinde yazım birliği yoktur. Bu durum mürettibin kendi döneminin değil şiirleri aldığı kaynaklardaki imla özelliklerini koruduğunu düşündürmektedir:

" بن " ben (7a/ 1, 49a/ 5) ; " men (7a/ 2, 49a/4).

\footnotetext{
${ }_{9}$ Gerek şiirlerin imlası gerekse şairlerin yaşadıkları yüzyıllar dikkate alındığında mecmuadaki şiirlerin bu üç dönemi kapsadığı ifade edilebilir.

Türkçenin dönemleri hakkında bilgi için bkz: Timurtaş, F. K. (1994). Eski Türkiye Türkçesi XV. Yüzyıl. İstanbul: Enderun Kitabevi. s. VIII; Gülsevin, G. \& Boz, E. (2004). Eski Anadolu Türkçesi. Ankara: Gazi Kitabevi. s. 56-77.

10 Örneklerdeki kelimelerin yer bilgisi "mecmuadaki varak numarası/ satır numarası" şeklindeki sırayla verilmiştir (Satır numarasına başlıklar da dâhildir).
}

SEFAD, 2020; (44): 213-250 
2) Vezin gereği yapılan imaleler ${ }^{11}$ yazımda da gösterilmiştir. Bu nedenle bazı eklerde imla birliği yoktur:

yönelme hâli eki " حقا" Hakḳa (19a/ 5), " حقه " Ḥaḳka (21a/ 3).

3) Bazı kelimelerde hareke unutulmuş veya yazılmamıştır. Aynı şiirde aynı kelimenin biri harekeli diğeri harekesiz yazılabilmektedir. Harekesiz kelimeler genelde misra sonlarındaki rediflerdir:

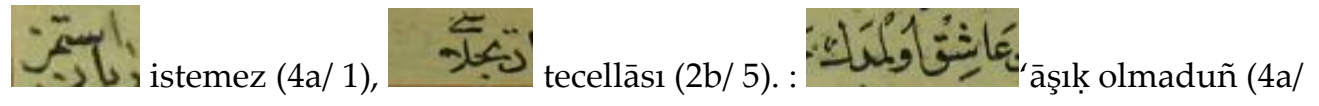

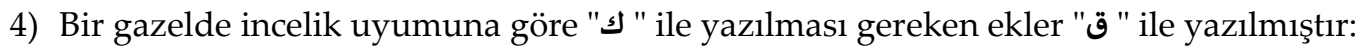

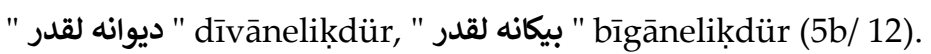

5) خ خ " harfiyle yazılması gereken bazı kelimelerin " " ile yazıldığı örnekler de mevcuttur:

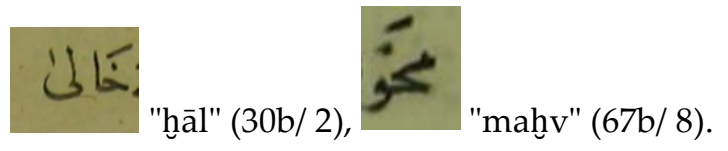

\section{MECMÛ'A-İ İLÂHIYŶA'IN MUHTEVASI}

\section{1. Mecmuadaki Şairler ve Şiirleri}

Mecmû‘a-i İlâhiyât'ta 6'sı mahlassız 135 şiir bulunmaktadır. Bunların 102'si gazel, 10'u kaside, 3'ü müfred, 2'si terci-i bend, 1'i murabba, 1'i muaşşer, 1'i mesnevi ve 14'ü koşmadır. Bir şiirin ise nazım şekli tespit edilememiştir. Mecmuada mahlası bulunan 27, mahlassız 7 ve mahlasına kaynaklardan ulaşılan 1 şair olmak üzere 34 şair vardır. Şiirlerin şairler ve nazım şekillerine göre dağılımı aşağıdaki tabloda gösterilmiştir.

Tablo 1. Şiirlerin Şair ve Nazım Şekline Göre Dağılımı

\begin{tabular}{|c|c|c|c|c|}
\hline & Mahlas & $\begin{array}{l}\text { Nazım } \\
\text { Şekli }\end{array}$ & $\begin{array}{l}\text { Şiir } \\
\text { Sayısı }\end{array}$ & Sayfa numarası \\
\hline 1 & Abdurraḥman & Koşma & 1 & $41 \mathrm{~b}$ \\
\hline \multirow[t]{2}{*}{2} & \multirow{2}{*}{$\begin{array}{ll}\text { Âşık } & \text { Paşa/ } \\
\text { Muhlis } & \text { Oğlu } \\
\text { Paşa } & \\
\end{array}$} & Gazel & 1 & $18 \mathrm{~b}$ \\
\hline & & Koşma & 3 & $1 b, 2 b, 32 a$ \\
\hline 3 & Câmî & Gazel & 4 & $56 a, 60 a(2), 77 b$ \\
\hline 4 & Cemâlî & Gazel & 4 & $29 a, 64 a, 70 a, 71 a$ \\
\hline 5 & Cemâl-i Halvetî & Gazel & 12 & $1 \mathrm{~b}, 2 \mathrm{a}, 7 \mathrm{~b}(2), 29 \mathrm{~b}, 57 \mathrm{~b}, 64 \mathrm{~b}, 65 \mathrm{a}, 67 \mathrm{~b}, 68 \mathrm{a}, 71 \mathrm{a}, 77 \mathrm{a}$ \\
\hline \multirow[t]{2}{*}{6} & \multirow[t]{2}{*}{ Eşrefoğlu Rûmî } & Gazel & 1 & $3 b$ \\
\hline & & Koşma & 1 & $30 a$ \\
\hline 7 & Fütûhî & Koşma & 1 & $66 a$ \\
\hline 8 & Garîbî & Gazel & 1 & $67 a$ \\
\hline 9 & Gülşenî & Gazel & 4 & $58 a, 63 a, 65 b, 69 b$ \\
\hline 10 & Hâce Hâfız & Gazel & 1 & $20 \mathrm{a}$ \\
\hline 11 & Hakîkî & Gazel & 31 & $4 b, 5 a, 5 b, 6 a, 6 b, 8 a, 11 a, 11 b, 12 b(2), 13 a, 13 b, 14 b$ \\
\hline
\end{tabular}

${ }^{11}$ Aruz vezni ile ilgili ayrıntılı bilgi için bkz.: Düzenli, M. B. \& Bulak, Ş. (2018). Aruz vezninin Türk şiirine tatbikinde başvurulan imlâ/ telaffuz tasarrufları ve mahiyetleri. Selçuk Üniversitesi Türkiyat Araştırmaları Dergisi, 43, 145-171. https://doi.org/10.21563/sutad.447273. 


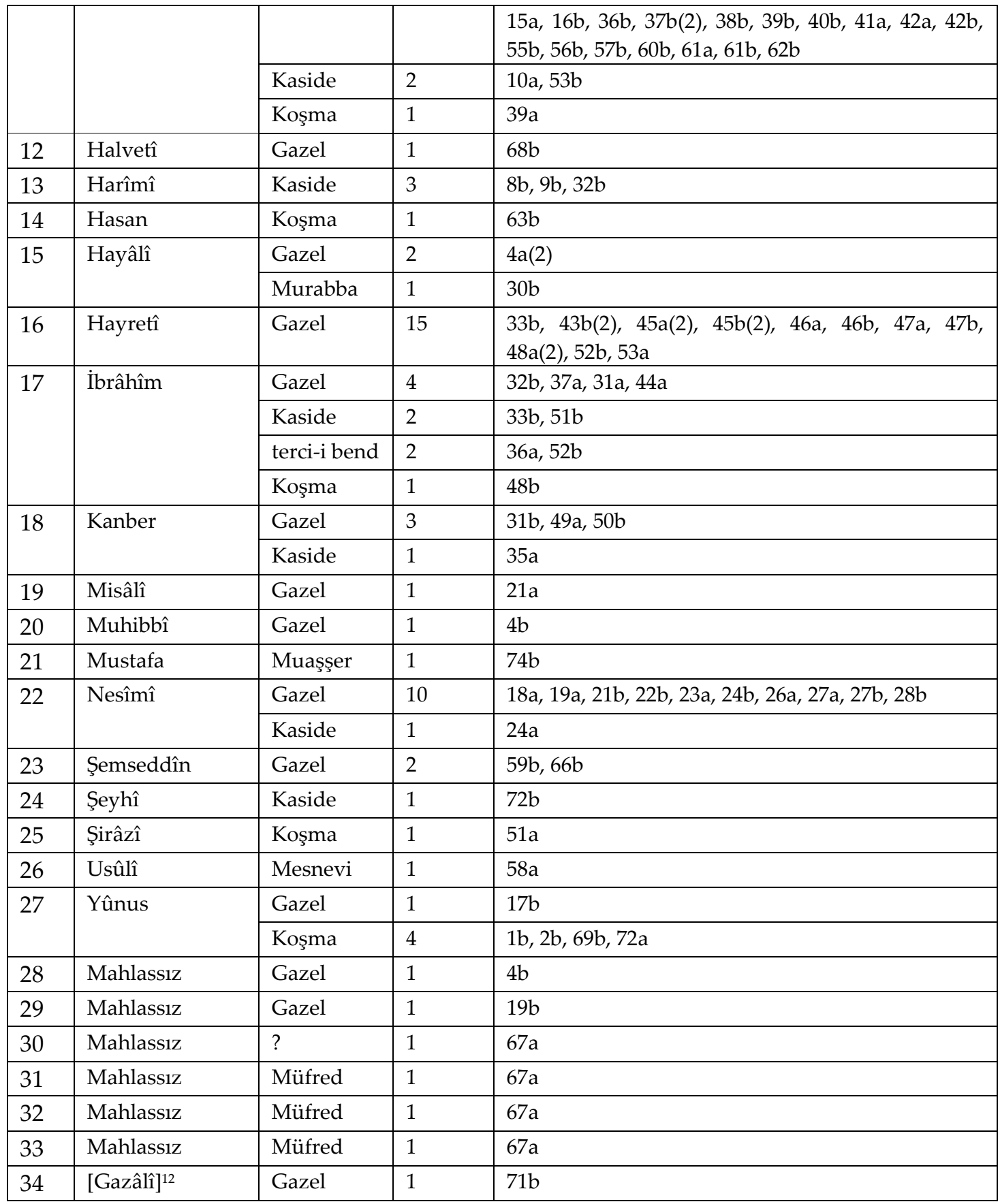

Mecmuadaki gazeller genellikle 5, 7 ve 9 beyitten oluşmaktadır ancak daha çok beyitli gazeller de vardır. Kasidelerde ise beyit sayısı fazla değildir. En çok beyitli kaside 35 beyitten ibarettir (32b). Mecmuada yer alan tek mesnevi de 31 beyittir (58a). Terci-i bendden alınmış manzumelerin ise biri 13 diğeri 7 beyittir $(36 a, 52 b)$.

67a'da bulunan der-kenarlar, Harîmî'nin tevhid türündeki kasidesi (9b) ve Nesīmī'nin naatı (24a) hariç diğer şiirlerin tamamı birer ilahi hüviyetindedir. Kaside nazım şekliyle yazılmış şiirlerin de ilahi türünde olduğu ve Klasik Türk edebiyatındaki kasidelerle kafiye düzeni ve uzunluğunun dışında benzerlik göstermediği görülmektedir.

12 Abdulmahmûd (2019) bu şiiri Gazâlî'ye atfetmektedir. (s. 421).

SEFAD, 2020; (44): 213-250 
Mecmuada en çok şiiri olan şair 31 gazel 2 kaside, 1 koşma ile Hakîkî, ondan sonra 15 gazelle Hayretî, 10 gazel 1 kasideyle Nesîmî ve 12 gazelle Cemâl-i Halvetî'dir.

Şairlerden ölüm yılı tespit edilebilenler şunlardır: Âşık Paşa (ö. 733/1332), Câmî (ö. 898/1492), Cemâl-i Halvetî (ö. 912/1506), Eşrefoğlu Rûmî (ö. 874/1469-70), Gazâlî (ö. 505/1111) Gülşenî (ö. 940/1534), Hâce Hâfız (ö. 792/1390[?]), Hakîkî (ö. 893/1487-88), Hayâlî (ö. 964/1556-57), Hayretî (ö. 941/1534-35), İbrâhîm Tennûrî (ö. 887/1482), Muhibbî (ö. 974/1566), Nesîmî (ö. 820/1417[?]), Şeyhî (ö. 832/1429), Usûlî (ö. 945/1538-39), Yûnus (ö. 720/1320[?]). ${ }^{13}$

Kaynaklarda mecmuada yer alan bazı şairlerle aynı mahlası kullanan şairlere rastlanmıştır. $\mathrm{Bu}$ şairlerin divanlarıyla veya yayımlanmış şiirleriyle mecmuadaki şiirler karşılaştırıldığında mecmuadaki şiirler ve bu şiirlerin hangi şaire ait olduğu tespit edilemediği için söz konusu şairlerin ölüm tarihleri de verilememiştir. Bu şairler şunlardır: Cemâlî, Fütûhî, Garîbî, Halvetî, Harîmî, Hasan, Kanber, Misâlî, Mustafa, Şemseddin ve Şirâzî.

Şairler arasında yaşadığı dönem tespit edilenler 14,15 ve 16 . yüzyıllarda eserlerini vermişlerdir. Bu tarihler klasik edebiyatın yükseliş gösterdiği, değerli şairlerin yetiştiği dönemlerdir. Bu asırlarda aynı zamanda özellikle şiirlerinde mahalli unsurlara yer veren şairlerin şiirlerinde sadelik görülmektedir. Tasavvuf ise birçok şair tarafından şiirlerin önde gelen unsuru olarak kullanılmıştır. Söz konusu mecmuadaki şairler de bu unsurlara şiirlerinde yer vermişlerdir. Bu şairlerin ortak noktaları dil, seslendikleri kitle, üslup, duyuş, tema ve zümre etrafında birleşmektedir. Zira Hâfız, Câmî, Nesîmî ve Hakîkî'nin bir şiiri hariç diğer şairler şiirlerini o dönemin lirik şiirlerine göre anlaşılır bir Türkçeyle yazmış, hepsi öğüt verici/öğretici ve telkin edici bir üslup kullanmış, benzer hisleri benzer temalarla (İlahî aşk, pişmanlık, dünya kayıtlarından ayrılmak, mürşide bağlanmak vb.) aktarmışlardır.

Mecmuadaki şairlerin geneli tasavvufla meşgul olan ve bir tarikata bağlı hatta tarikat kurucusu şairlerdir. Cemâl-i Halvetî "Halvetî" tarikatının "Cemâliye" kolunu, Eşrefoğlu Rûmî "Kadirîlik" tarikatının "Eşrefiye" kolunu, Gülşenî "Halvetî" tarikatının "Gülşeniye" kolunu, Hakîkî "Bayramiye" tarikatını, İbrâhim Tennûrî "Bayramiye" tarikatının "Tennûriye" kolunu kurmuştur. Ayrıca Hayretî "Bektâşilik", Usûlî "Gülşenîlik" tarikatına ve Nesîmî de "Hurûfîlik" fırkasına bağlıdır (Azamat, 2000, C. 21, s. 301; Bilgin, 2007, C. 33, s. 5; Boz, 2013, C. 44, s. 137; Kaya, 2012, C. 1, s. 213; Pekolcay \& Uçman, 1995, C. 11, s. 480; Tatcı, 1998, C. 17, s. 61; Tayşi, 1993, C. 7, s. 302; Uzun, 2000, C. 21, s. 35).

$\mathrm{Bu}$ şairlerin çoğu aynı dönemde yaşadıkları için birbirlerinden de etkilenmişlerdir. Hayâlî, Hayretî ve Usûlî Gülşenî'den etkilenmişler ve onun tarikatına girmişlerdir (Kurnaz, 1998, C. 17, s. 6; Tatc1, 1998, C. 17, s. 1; Kaya, 2012, C. 1, s. 1). İbrâhim Tennûrî'nin ise Yûnus Emre'den etkilediğini söylemek mümkündür. Hatta İbrâhim Tennûrî bazı manzumelerinde Yûnus Emre gibi Âşık mahlasını kullanmıştır. (Uzun, 2000, C. 21, s. 356).

Çalışma sırasında kaynaklarda mecmuadaki şairlerle aynı mahlası kullanan farklı şairlere rastlanmıştır. Farklı kaynak ve tezkirelerdeki bu şairlerin şiirleri arasında mecmuada

13 Ölüm tarihleri TDV İslam Ansiklopedisi ve Türk Edebiyatı İsimler Sözlüğü (TEİS) web sitelerinden alınmıştır (https://islamansiklopedisi.org.tr; http://teis.yesevi.edu.tr). 
geçen şiirler bulunmadığı için kimlikleri tespit edilememiştir. Ayrıca divanları tespit edilen şairlerin bir kısmının mecmuada geçen şiirleri divanlarında bulunamamıştır. ${ }^{14}$

Mecmuada zaman zaman şiirin kime ait olduğunu tespitte yanlışlıklar mevcuttur. Örneğin şiirin mahlas beytinde Kanber mahlası geçmesine rağmen başlıkta Harîmî'ye ait gösterilmiş (bkz. 35a); yine Nesîmî'ye ait iki şiirin mahlası değiştirilerek Cemâlî'ye (bkz. 70a) ve Yûnus Emre'ye atfedilmiştir (bkz. 17b). Bu hatalar direkt mürettibin veya müstensihin tasavvurundan kaynaklanabileceği gibi derleme yapılan kaynaklardaki hatalı şiirlerin divanlarla karşılaştırma yapılmadan alınmasından da ileri gelebilir.

Mecmuadaki Âşık Paşa'ya ait gösterilen bir gazele (1b) Yûnus Emre Divani'nda da rastlanmıştır (Tatcı, 2008, s. 209). Fakat Ergun'a (1936) göre bu şiir Âşık Paşa'ya aittir (C. 1, s. 138). Söz konusu şiir Gölpınarlı'nın (1936) yayımladığı Âşık Paşa'nın Şiirleri makalesinde ise yoktur. Mecmualarda bu karışıklık aynı yüzyılda veya farklı dönemde yaşamış birden fazla şairin aynı mahlası kullanmasından kaynaklanmış olabilir.

Mecmuada yer alan şiirlerin bazıları divanlarda bulunanlarla karşılaştırıldığında belirli farklılıklar gözlemlenmiştir. ${ }^{15}$ Yaşar Aydemir mecmualardaki şekil değiştirmiş şiirleri iki gruba ayırarak ilk grubu Yunus Emre, Ahmet Yesevi, İsmail Hakkı Bursavi gibi tasavvufi kişilikleri ön plana çıkmış isimlerin oluşturduğunu ve bu grupta bulunan şiirlerin çok geniş çevrede okunup ezberlendiğini ve mesaj verme tarafı ağır bastığı için çoğaltılırken orjinaline sadık kalma anlamında çok fazla hassasiyet gösterilmediğini, ekleme ve çıkarmaların daha rahat yapıldığını söylemektedir (Aydemir, 2007, s.134). Bu bağlamda Mecmû'a-i İlâhiyât'taki şairlerin bu ilk gruba dâhil olduğu ve ekleme çıkarmaların da bundan kaynaklandığı öne sürülebilir.

\section{2. Mecmuadaki Şiirlerin Vezin ve Kafiye Özellikleri}

Mecmû'a-i İlâhiyât'ta bulunan şiirlerde kafiyeden çok kelimeden oluşan redif tercih edilmiştir (gerek, gönül, ışk, ne fayide, dervişler, es-sabru miftâhü'l-ferec, bulmışam, kayusu degül vd.). Bu durum mecmuayı derleyenin seçtiği şairlerin belli bir düşünceyi aktarma ve ilahî aşkı anlatma kaygısında olduğunu göstermektedir. Rediflerin emir fiilinden oluşması ise öğüt verme kaygısının da olduğuna işarettir (işit, fârig ol, ol yüri, olmayan hiç gelmesün, olan gelsün berü, arzu eyleme vd.).

Şiirlerde kullanılan vezin kalıpları ve sayıları ise aşağıdaki tabloda gösterilmiştir.

Vezin kusurlarına sıkça rastlanan mecmuadaki şairlerin kaygısının sanatlarını göstermek olmadığı dikkate alındığında bu hataların olağan olduğu söylenebilir. Ayrıca şairlerin divanları ve şiirlerinin neşredildiği diğer kaynaklarla mecmuadaki şiirler karşılaştıııldığında bazı şiirlerin aslında vezin kusuru olmadığı fakat mecmuaya alınan versiyonunda vezin kusuru olduğu tespit edilmiştir. Bu durumun sebebi mürettip veya müstensihin şiiri geçirirken yaptığı ya da şiirin alındığı kaynaktaki hata olabilir.

\footnotetext{
${ }^{14} \mathrm{Bu}$ gibi durumların olası sebepleri için bkz: Aydemir, 2007, s. 132).

${ }^{15} \mathrm{Bu}$ karşılaştırma Tablo 3 'te yapılmış ve farklılıklar dipnotlarda gösterilmiştir.
}

SEFAD, 2020; (44): 213-250 
Tablo 2. Mecmuada Kullanılan Vezinler

\begin{tabular}{|c|c|c|}
\hline Vezin & Bahir & Sayı \\
\hline Fâ'ilâtün Fâ'ilâtün Fâ'ilâtün Fâ'ilün & Remel & 42 \\
\hline Mefâ‘̂̂lün Mefâ‘îlün Fe'ûlün & Hecez & 19 \\
\hline Mefâ‘̂̂lün Mefâ‘îlün Mefâ‘̂̂lün Mefâ‘̂̂lün & Hecez & 18 \\
\hline Müstef'ilün Müstef'ilün Müstef'ilün Müstef'ilün & Recez & 7 \\
\hline Fâ'ilâtün Fâ'ilâtün Fâ'ilün & Remel & 6 \\
\hline Mef'ûlü Mefā‘̂̂lü Mefâ‘̂̂lü Fe'ûlün & Hecez & 6 \\
\hline Mef'ûlü Fâ'ilâtü Mefâ'îlü Fâ'ilün & Muzâri' & 6 \\
\hline Fe'ilâtün Mefâ'ilün Fe'ilün & Cedîd & 4 \\
\hline $\mathrm{Fe}^{\prime}$ ilâtün $\mathrm{Fe}^{\prime}$ ilâtün $\mathrm{Fe}$ 'ilâtün $\mathrm{Fe}^{\prime}$ ilün & Remel & 2 \\
\hline Fâ'ilâtün Fâ'ilâtün Fâ'ilâtün Fâ'ilâtün & Remel & 1 \\
\hline Mef'ûlü Mefâ'ilün Fe'ûlün & Hecez & 1 \\
\hline Mef'ûlü Fâ'ilâtün Mef'ûlü Fâ'ilâtün & Muzâri' & 1 \\
\hline Mefâ'ilün Fe'ilâtün Mefấilün Fe'ilün & Müctes & 1 \\
\hline Müfte'ilün Müfte'ilün Fấilün & Serî' & 1 \\
\hline Müfte'ilün Mefâ'ilün Müfte'ilün Mefâ'ilün & Recez & 1 \\
\hline \multicolumn{2}{|l|}{ 7'li hece } & 4 \\
\hline \multicolumn{2}{|l|}{ 8'li hece } & 9 \\
\hline \multicolumn{2}{|l|}{ Tespit edilemeyen } & 6 \\
\hline & Toplam: & 135 \\
\hline
\end{tabular}

\section{MECMÛ‘A-İ İLÂHIYÂT'IN MECMUALARIN SISTEMATIK TASNIFİ PROJESİ (MESTAP)'NE GÖRE MUHTEVA TABLOSU}

Süleymaniye Kütüphanesi Mehmed Arif Mehmed Murad Bölümü 48 Numaralı Mecmû'a-i İlâhiyât'ın muhtevasının aktarılmaya çalışıldığı bu bölümde tablo hazırlanırken şiirlerin okunuşunda mecmuadaki şiirlerin ayrı ayrı dil özellikleri (Eski Anadolu Türkçesi, Eski Osmanlı Türkçesi ve Klasik Osmanlı Türkçesi) esas alınmış ve olduğu gibi yazılmıştır. Mecmuada geçen şiirlerin yer aldığı divanlardan tespit edilebilenlerin tamamı taranmış ve farklılıklar dipnotta gösterilmiştir. Fakat divanda bulunan ve divandakiyle farklılık göstermeyen şiirlerin divanlarda bulunduğu yere dair bir bilgiye dipnotlarda yer verilmemiştir. Şiirlerin divanlarla karşılaştırılmasında dipnotta önce mecmuadaki kelime sonra divandaki kelime yazılmış ve bu kelimenin hemen yanına divanı neşreden kişi, yayın tarihi, şiirin geçtiği divandaki sayfa numarası verilmiştir. Bu karşılaştırmada vezin veya anlam açısından hangi kelime uygunsa köşeli parantez içinde belirtilmiş ve yine önerilerle diğer notlar da köşeli parantezle [ ] verilmiştir. Şairi tespit edilen mahlassız şiirler ile şiirin başında şairi belirtilen ancak mahlas bulunmayan şiirlerin şairleri ise mahlas sütununa köşeli parantezle [ ] kaydedilmiştir.

"Başlık/ Açıklamalar" sütununda önce varsa şiirin başlığına ve "taksim, /" işaretinden sonra da mecmuada geçen özel hususiyetler ve notlara yer verilmiştir. Mecmuadaki derkenarlar sayfa numarası kısmında "Dk" kısaltmasıyla gösterilmiştir.

Sayfa numarası kısmında mecmuadaki numaralandırma hatalı olduğu için 8b'den itibaren yeniden bir numaralandırma yapılmış ve önce mecmuada yazan varak numarası 
ardından sonradan verilen numara yazılmıştır. Bu hususla ilgili ayrıntılara dipnotlarda değinilmiştir.

Metinde kullanılan işaretler ise şunlardır:

\begin{tabular}{|l|l|}
\hline $\begin{array}{l}\text { Köşeli parantez } \\
\text { [ ] }\end{array}$ & $\begin{array}{l}\text { Misrada vezin gereği eksik olan kısımların ve divandan tamamlanan } \\
\text { kisımların eklenmesinde. }\end{array}$ \\
\hline $\begin{array}{l}\text { Yay ayraç } \\
\text { ( ) }\end{array}$ & Misrada vezin gereği fazla olan kısımların çıkarılmasında. \\
\hline $\begin{array}{l}\text { Mecmuadan ekran } \\
\text { alıntısı }\end{array}$ & Arapça, Farsça şiirlerde ve okunamayan kısımlarda. \\
\hline
\end{tabular}

\section{SONUÇ}

Süleymaniye Kütüphanesi Mehmed Arif Mehmed Murad bölümündeki 48 numaralı Mecmû'a-i İlâhiyât'ın incelendiği bu çalışmayla söz konusu mecmuanın ilahi mecmualarının genel formuna benzer şekilde tertip edildiği belirlenmiştir. Zira tezhip bakımından sade olma, mürettibin belli olmaması, çoğu yazmada rastlanan mukaddime, sebeb-i telif, telif tarihi vb. bilgilere yer verilmemesi, hem hece hem aruzla yazılan şiirleri barındırma, belli başlı mutasavvıfların şiirlerinin sayıca diğer şairlerin şiirlerinin çok önünde oluşu ve bazılarında bestelendiği makamın kaydedilmesine rağmen çoğunda bu özelliğin olmaması gibi ilahi mecmualarının belirli özellikleri bu mecmuada da görülmektedir. İçine aldığ şairlerin yaşadığı yüzyıllar ve şiirlerin imla özellikleri göz önüne alınarak 16. yüzyıl sonu veya 17. yüzyıl başlarında derlendiği tahmin edilen mecmuada tertip tarihi ve mürettiple ilgili bir bilgiye yer verilmemiştir. 86 varaktan oluşan ve 34 şaire ait 135 şiirin bulunduğu mecmua, geneli bir tarikata mensup olan tasavvuf şairlerinin ilahi aşk, pişmanlık, dünya kayıtlarından ayrılmak, mürşide bağlanmak vd. konulardaki ilahilerini barındırmaktadır. Mecmuadaki ilahiler divan ve diğer kaynaklardaki ilahilerle karşılaştırıldığında bir kısmının mecmuada bulunan şekillerinin vezin veya anlam açısından doğru olduğu tespit edilmiştir. Bu durum mecmuadaki bu ilahilerin şairinden aktarılan ilk şekilleri olabileceği ihtimalini kuvvetlendirmektedir. Sonuç itibariyle çeşitli özellikleriyle tanıtılmaya çalışılan Mecmû'a-i İlâhiyât'ın hem MESTAP'a hem de diğer mecmua çalışmalarına katkı sağlayacak nitelikte bir eser olduğu söylenebilir.

\section{SUMMARY}

The number of studies on poetry collections is increasing day by day. ${ }^{16}$ However, hymn collections occupy very little place among these works. ${ }^{17}$ The importance of hynm

\footnotetext{
${ }^{16}$ For studies on poetry collections, cf.: Giynaş, K. A. (2011). A bibliography of studies about poetry collections. Journal of Faculty of Letters, 25, 245-260. Access address: http://sefad.selcuk.edu.tr/sefad/article/view/97. Access date: 15.03.2020; Tanyıldız, A. (2012). About the publications of poem journals. The Journal of International Social Research, 5/21, 224-239.Access address: https://www.academia.edu/26982802/Şi̇iR_MECMÛALARININ_NEŞRİ_HAKKINDA. Access date: 15.03.2020.

For current theses on collections cf.: https://tez.yok.gov.tr/UlusalTezMerkezi/.

For also the works on collections cf.: https://www.osmanliedebiyati.com; https://mestap.com.

17 There are twelve theses, two articles and a declaration about the hymn collections that can be accessed online;

Manifesto: Köksal, M. F. (2017). A type of writing neglected in religious-sufi Turkish musical studies: divine collections and an important divine collection. Ş. Özdemir \& A. Gün (Ed.), in the From Past to Present İnternational Religious Müsic Symposium (p. 331-336). Ankara: Kibatek.
}

SEFAD, 2020; (44): 213-250 
collections in terms of both literature and language and history cannot be ignored. For this reason, increasing the studies on the mentioned works is important for the social sciences.

In this article, the Mecmûa-i İlâhiyât numbered 48 at Süleymaniye Library Mehmed Arif Mehmed Murad department, was examined in terms of form and content. The purpose of selecting this collection as the subject is to contribute to the relevant studies by revealing the value of the hymn collections in collections.

The method of the study was shaped according to the Mecmualarin Sistematik Tasnifi Projesi/ Systematic Classification Project of Collections (MESTAP) ${ }^{18}$. In this context, the hymns in the collection were conveyed with a detailed content table.

There is no record of compiler and compilation date in the collection. Although the compiler of the collection is not certain, we think that the following couplet, who was in the last leaf and asked for prayer to the clerk, belongs to the compiler:

Ḩayra yazsun şerrini anuñ Kirāmen kātibīn

Her kim añarsa du'ādan işbu ḩațtuñ kātibin

According to the poets, whose identity we can determine in the collection, there are poems belonging to the 14th, 15th and 16th centuries. Accordingly, the collection was most likely compiled in the late 16th or early 17th century. However, considering both the poets whose identity has not been determined, and the binder, paper type and some spelling features, it is likely that the collection was compiled after these dates.

As it can be understood from the name, Mecmûa-i İlâhiyât was compiled on the basis of poetry/verse type, since all the poems, except for a few poems, are hymn type. However, even if the compilation and classification according to the verse type are clarified, it is not possible to mention an absolute arrangement feature in terms of form. Because, although most of the hymns in the collection are written in ghazal form, is also included ode, müfred (a poetry/verse form consisting of one couplet), terci-i bend (a form of verse that consists of weirs), murabba (a form of verse that consists of strophes), muaşşer (a form of verse consisting of ten line weirs), mesnevi (a form form of verse, each couplet of which rhymes in itself) and koşma (a form of verse that consists of strophe) and these are not included in a regular order.

Articles: Gürbüz, M. (2019). Hymn and prayer journal numbered 13229 in Konya Metropolitan Municipality Koyunoğlu Museum and Library. Academic Journal of Language and Literature, 3/4, 179-220. https://doi.org/10.34083/akaded.656025.

Ciğa, Ö. (2016). Number 1626 chant magazine in Mevlana Museum Library. Journal of Dicle University Institute of Social Sciences, 17, 85-102. Access address http://www.e-dusbed.com/Dusbed/ArchiveIssues/PDF/3960263b-6868e711-80f0-00224d68272d. Access date: 15.03.2020.

Theses: thesis tags are given after the bibliography.

18 The Systematic Classification of Collections Project is a project initiated by Mehmet Fatih Köksal and supported by many, from academics to students who are researching Old Turkish Literature. "The aim of the project is primarily the detailed classification and documention of all the collections, primaraly poetry collection, and subseqently literary works. The project will be carried out in the form of theses to be made by the graduate - preferably graduate - students of the field of Old Turkish Literature who have accepted to participate."

(Köksal, 2012a, p. 422). Project's website: https://mestap.com/. 
There is an error in leaf numbering in the work consisting of 86 leaves. In some leafs, the same leaf number was rewritten a second time. The mismatch in terms of the number of leafs with the record in manuscript is due to this error when numbering the leaf.

There are also some mistakes in determining who the poem belongs to in collection from time to time. For example, although the name Kanber is mentioned in the pseudonym, Harîmî is shown in the title (cf. 35a); similarly, the pseudonym of two poems belonging to Nesîmî was changed and attributed to Cemâlî (cf. 70a) and Yûnus Emre (cf. 17b).

There are 135 poems, 6 of which are not pseudonym, in the collection. Of these, 102 ghazals, 10 ode, 3 müfred (a poetry/ verse form consisting of one couplet), 2 terci-i bend (a form of verse that consists of weirs), 1 murabba (a form of verse that consists of strophes), 1 muaşşer (a form of verse consisting of ten line weirs), 1 mesnevi (a form form of verse, each couplet of which rhymes in itself) and 14 is koşma (a form of verse that consists of strophe). Also the poetry/verse form of a poem could not be determined.

In the collection there are 34 poets, 27 of whom have a pseudonym, 7 without a pseudonym, and 1 poet whose pseudonym we can access from the sources. The majority of poets in the collection are busy with sufism and are bound to a cult, even the founders of cult.

From the poets who have poetry in the collection, we can identify the year of death are: Âşsık Paşa (ö.733/1332), Câmî (ö.898/1492), Cemâl-i Halvetî (ö. 912/1506), Eşrefoğlu Rûmî (ö. 874/1469-70), Gazâlî (ö.505/1111) Gülşenî (ö. 940/1534), Hâce Hâfız (ö.792/1390[?]), Hakîkî (ö.893/1487-88), Hayâlî (ö.964/1556-57), Hayretî (ö.941/1534-35), İbrâhîm Tennûrî (ö.887/1482), Muhibbî (ö.974/1566), Nesîmî (ö.820/1417[?]), Şeyhî (ö.832/1429), Usûlî (ö.945/1538-39), Yûnus (ö.720/1320[?]).

The collection, which contains hymns about divine love, regret, leave world ties, connect to murshid etc. topics, is similar to the general form of other hymn collections. For instance, being plain in terms of gilding, not being certain compiler and compilation date, hosting poems written with both syllables and aruz(a form poetry/verse of Old Turkish Literature), giving more place to the poems of certain sufi poets etc. some features of the hymn collections are seen in this collection.

As a result, it can be said that Mecmû'a-i İlâhiyât, which is tried to be introduced with its various features, is a work that will contribute to both MESTAP and other collection studies.

SEFAD, 2020; (44): 213-250 
Makale Bilgileri

Etik Kurul Kararı:

Etik Kurul Kararından muaftır.

Katılımcı Rızası:

Katılımcı Yoktur

Mali Destek:

Çalışma için herhangi bir kurum ve projeden mali destek alınmamıştır.

Çıkar Çatışması:

Çalışmada kişiler ve kurumlar arası çıkar çatışması bulunmamaktadır.

Telif Haklart:

Telif hakkına sebep olacak bir materyal kullanılmamıştır.

Article Information

Ethics Committee Approval: Exempt from the Ethics Committee Decision.

Informed Consent:

No participant

Financial Support:

No financial support from any institution or project.

Conflict of Interest:

No conflict of interest.

Copyrights:

No material subject to copyright is included. 
Tablo 3. Süleymaniye Kütüphanesi Mehmed Arif Mehmed Murad Bölümü 48 Numaralı Mecmû‘a-i İlâhiyât'ın MESTAP'a Göre Muhteva Tablosu

\begin{tabular}{|c|c|c|c|c|c|c|c|}
\hline Yer nu: & & Süleymaniye Kütüphanesi Mehmed Arif Mehmed & Murad Bölümü, 48. & & & & \\
\hline$\underset{\substack{\infty \\
Z}}{\infty}$ & $\sum_{\substack{2 \\
\infty}}^{2}$ & 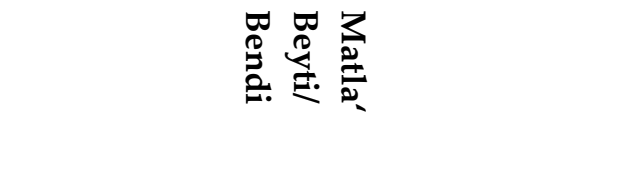 & 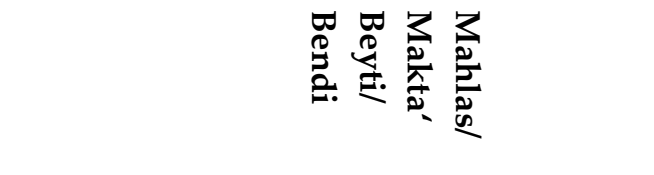 & 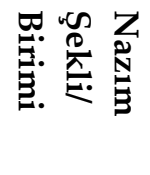 & 国 & $\underset{\substack{8 \\
8}}{\stackrel{3}{8}}$ & 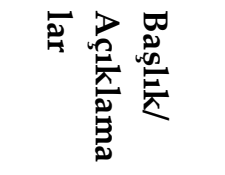 \\
\hline $1 b^{19}$ & $\begin{array}{l}\text { Cemāl-i } \\
\text { Halvetī }\end{array}$ & 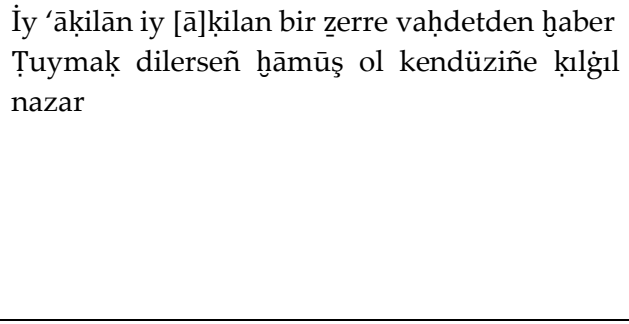 & $\begin{array}{l}\text { Miskīn Cemāl-i Halvetī Hakḳuñ yolına ḳāyim ol } \\
\text { Tā himmet-i pīrān ire tā görmeyesin daḩı şer }\end{array}$ & gazel/ 5 & ilahi & $\begin{array}{l}--.- \\
1--\cdot- \\
1--.- \\
1--.-\end{array}$ & $\begin{array}{l}\text { Min Kelāmi } \\
\text { Ba'żi'l Meşāyiḥ } \\
\text { Ravvaha'llāhu } \\
\text { Rūḥahüm ve } \\
\text { Min Kelāmi } \\
\text { Ba'żi'ş-şu'arā } \\
\text { Raḥimehümullā } \\
\text { h }\end{array}$ \\
\hline $1 b$ & 'Āşsk & $\begin{array}{l}\text { 'Işkuñ şarābın içeli } \\
\text { Ḳandalıgum bilimezem } \\
\text { Şöyle yoḳ oldum ben beni } \\
\text { İsteyüben bulımazam }\end{array}$ & $\begin{array}{l}\text { Minüm urduñ bünyādumı } \\
\text { ‘Āşık yazaldan adumı } \\
\text { Kodum ḳamunuñ dādını } \\
\text { 'Işşuñdan ayrılımazam²0 }\end{array}$ & koşma/ 7 & ilahi & $\begin{array}{l}\text { 8'li } \\
\text { hec } \\
\text { e }\end{array}$ & $\begin{array}{l}\text { Mevlānā 'Āşıłk } \\
\text { Paşa Rāst } \\
\text { Kuddise } \\
\text { Sirruhu }\end{array}$ \\
\hline $1 b$ & Yūnus & $\begin{array}{l}\text { Haḳ cihāna țoludur } \\
\text { Kimsene Haḳkı bilmez } \\
\text { Anı sen senden iste } \\
\text { O senden ayru olmaz }\end{array}$ & $\begin{array}{l}\text { Yūnus sözin añlarısañ }{ }^{21} \\
\text { Ma'nisini diñleriseñ }{ }^{22} \\
\text { Saña eyü dirlik }{ }^{23} \text { gerek } \\
\text { Bunda kimsene kalmaz }\end{array}$ & koşma/ 6 & ilahi & $\begin{array}{l}8^{\prime} \text { li } \\
\text { hec } \\
\text { e }\end{array}$ & $\begin{array}{l}\text { Yūnus } \\
\text { Fermāyed }\end{array}$ \\
\hline $2 a$ & Cemāl-i & Ḥakịịat şemsinüñ her yir țolu iy cān tecellāsı & Cemāl-i Halvetī eydür anı nāmerd gözi görmez & gazel/ 7 & ilahi &.--- & Cemāl-i Hualvetī \\
\hline
\end{tabular}

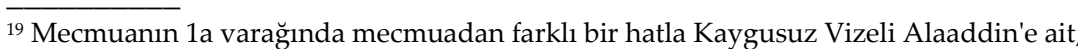

Evliyāya egri bakmañ kevn ü mekān elindedür

matlalı bir şiir vardır. (Gölpınarlı, 1932, s. 63; Ekinci, 2013, s. 166).

${ }^{20}$ Bu şiir hem Yünus Emre Dĩvānı'nda (Tatcı, 2008, s. 209) hem de Türk Şairleri 'nde Āşık Paşa'nın şiirlerinin arasında bulunmaktadır (Ergun, 1936, s. 138).

21 añlarısañ: añlarsañ (Tatc1, 2008, s. 122). [Vezin açısından Divan'daki uygundur.]

22 diñleriseñ: diñlerseñ (Tatcı, 2008, s. 122). [Vezin açısından Divan'daki uygundur.]

${ }^{23}$ eyü dirlik: bir 'amel (Tatc1, 2008, s. 122/103). [Vezin açısından Divan'daki uygundur.]

SEFAD, 2020; (44): 213-250 


\begin{tabular}{|c|c|c|c|c|c|c|c|}
\hline & Halvetī & Gider perde'i gözüñden görine cān tecellāsı & Gelüp merd ol ki maḥv ide seni yeksān tecellāsı & & & $\begin{array}{l}/ .-- \\
\text { /.-- } \\
\text { /.-- }\end{array}$ & $\begin{array}{l}\text { Kuddise } \\
\text { Sirruhu }\end{array}$ \\
\hline $2 b$ & 'Āşşı & $\begin{array}{l}\text { Benden mi baña bu elem } \\
\text { 'Işķdan mı yohsa derd ü gam } \\
\text { Bunca belā cevr ü sitem } \\
\text { Bilsem nedendür bilmezem }\end{array}$ & $\begin{array}{l}\text { 'Āşıḳda bu hayret nedür } \\
\text { Ma'şuḳdaġ şevket nedür } \\
\text { Dervīş buña hiikmet nedür } \\
\text { Bilsem nedendür bilmezem }\end{array}$ & koşma/ 5 & ilahi & $\begin{array}{l}8^{\prime} \text { li } \\
\text { hec } \\
\text { e }\end{array}$ & 'Āşık rāst \\
\hline $2 b$ & Yūnus & $\begin{array}{l}\text { Dōst yüzine baḳmaġa } \\
\text { Key șafā naẓar gerek } \\
\text { Dōst-ile }{ }^{24} \text { bilişmege } \\
\text { Cān gözine tīmārén gerek }\end{array}$ & $\begin{array}{l}\text { Yūnus imdi yavı var } \\
\text { Bulımasunª il ü şar } \\
\text { Kim H̦aḳ disün kim bāțıl } \\
\text { Dervīșe bāl ü per²7 gerek }\end{array}$ & koşma/10 & ilahi & $\begin{array}{l}\text { 7'li } \\
\text { hec } \\
\text { e }\end{array}$ & $\begin{array}{l}\text { Yūnus } \\
\text { Fermāyed }\end{array}$ \\
\hline $3 b$ & Eşrefog̀l1 & $\begin{array}{l}\text { Anuñ derdi-ile dāyim yana }{ }^{28} \text { bu yüregim yana } \\
\text { Ḳodı cānumda 'sşḳ odın ezelden tā ebed yana }\end{array}$ & 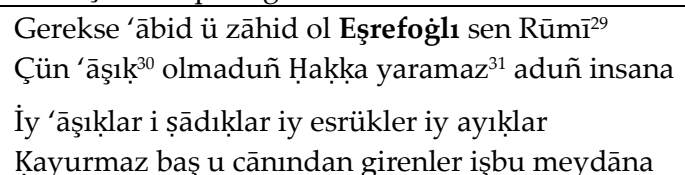 & gazel/ 10 & ilahi & $\begin{array}{l}--- \\
\text { /.-- } \\
\text { /.--- } \\
\text { /.--- }\end{array}$ & $\begin{array}{l}\text { Eşrefoġlı } \\
\text { Fermāyed }\end{array}$ \\
\hline $4 a$ & Hayālī & $\begin{array}{l}\text { Gerçi³2 kim cigerler ḳanıdur 'ışḳ } \\
\text { Baña șor kim ne cānlar cānıdur '1şḳ }\end{array}$ & $\begin{array}{l}\text { Hayālī gāh olur sulțān benüm dir } \\
\text { Ki anuñ bende-i fermānıdur 'ışḳ }\end{array}$ & gazel/ 5 & ilahi & $\begin{array}{l}---- \\
1 .--\end{array}$ & $\begin{array}{l}\text { Huyālī Rāst } \\
\text { Rahịimehullāhu }\end{array}$ \\
\hline $4 a$ & Hayālī & $\begin{array}{l}\text { Faḳr-ile faḩr eyleyen dergāh-ı sulțān istemez } \\
\text { Dūd-ı āhı sāyesinde țāḳ-ı eyvān istemez }\end{array}$ & $\begin{array}{l}\text { İy Hayālī bī-tekellüf bir ḳadeh }{ }^{33} \text { nūş eyleyen } \\
\text { Minnet-ile Ḥıżr elinden āb-1 hayvān istemez }\end{array}$ & gazel/ 5 & ilahi & $\begin{array}{l}-.-- \\
1-.-- \\
1-.-- \\
1-.-\end{array}$ & Velehü Eyżan \\
\hline
\end{tabular}

${ }^{24}$ dōst-ile: dōstla (Tatc1, 2008, s. 152). [Vezin açısından Divan'daki uygundur.]

25 tīmār: bīdār (Tatcı, 2008, s. 152)

${ }^{26}$ bulımasun: bulmayasın (Tatc1, 2008, s. 152).

27 dervīşe bāl ü per: dervīş burc u bār (Tatcı, 2008, s. 152). [Vezin açısından Divan'daki uygundur.]

${ }^{28}$ yana: yine (Çelebi, 2015, s. 69).

29 Eşrefog̀lı sen Rūmī: Eşrefog̀lı Rūmī sen (Çelebi, 2015, s. 69). [Mana açısınsan Divan'daki uygundur.]

30 ‘āşık: vāṣıl (Çelebi, 2015, s. 69)

${ }^{31}$ olmaduñ Ḩakka yaramaz: olmadın Ḥaḳa yazılmaz (Çelebi, 2015, s. 69).

32 gerçi: egerçi (Tarlan, 1992, s. 177). [Vezin açısından Divan'daki uygundur.]

33 bir ḳadeh: hūn-1 dil (Tarlan, 1992, s. 154). 


\begin{tabular}{|c|c|c|c|c|c|c|c|}
\hline $4 \mathrm{~b}$ & Muhibbīi & $\begin{array}{l}\text { İh̆tiyār-1 kașrin iden dergāh-1 sulțān }{ }^{35} \text { istemez } \\
\text { Zād-1 gamda[n] }{ }^{36} \text { özge hergiz kendüye nān } \\
\text { istemez }\end{array}$ & $\begin{array}{l}\text { İy Muhibbī yār elinden }{ }^{37} \text { bir kạahẹ nūş eyleyen } \\
\text { Ḥıżr elinden ger olursa āb-1 hayvān istemez }\end{array}$ & gazel/ 5 & ilahi & $\begin{array}{l}-.-- \\
1-.-- \\
1-.-- \\
1-.-\end{array}$ & $\begin{array}{l}\text { Muhibbī Rāst } \\
\text { Raḥimehullāhu }\end{array}$ \\
\hline $4 \mathrm{~b}$ & - & $\begin{array}{l}\text { Gerek ki ġușṣa-1 '1şḳı bu levh-i cāna yazam } \\
\text { Ki bir nefes ġam-1 'sşḳı iki cihāna yazam }\end{array}$ & $\begin{array}{l}\text { Gelürse vaḳtüme cennet cemali nūrınsız } \\
\text { Cehennemī oluban hụurisin zebāne yazam }\end{array}$ & gazel/ 5 & ilahi & $\begin{array}{l}. .-- \\
1 . .-- \\
1 .-.- \\
1 . .-\end{array}$ & Ġazel \\
\hline $4 \mathrm{~b}$ & Ḥaḳị̣̄̄ & 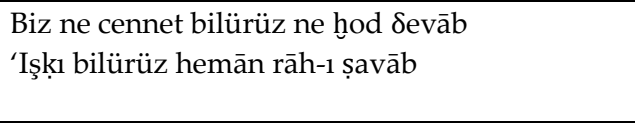 & $\begin{array}{l}\text { Ġayr-1 Ḥaḳ șig̀maz Ḥaḳīkī anda kim } \\
\text { Pāsubān şühb ola derbān āfitāb }\end{array}$ & gazel/ 11 & ilahi & $\begin{array}{l}-.-- \\
1-.-- \\
1-.- \\
\end{array}$ & $\begin{array}{l}\text { Ḥaḳīkī Rāst } \\
\text { Ravvaḥallāhu } \\
\text { Rūḥahu }\end{array}$ \\
\hline $5 a$ & Ḥaḳị̣̂ì & 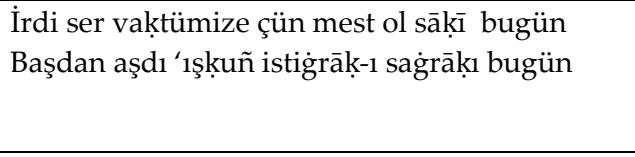 & $\begin{array}{l}\text { ‘Işḳ odı ḳıldı müdāvā tā Ḥaḳīḳi derdine } \\
\text { Cümle-i huuzzāạuñũ oldı nūr-ı aḥdāḳı bugün }\end{array}$ & gazel/ 12 & ilahi & $\begin{array}{l}-.-- \\
1-.-- \\
1-.-- \\
1-.-\end{array}$ & Velehü Eyżan \\
\hline $5 b$ & Ḥaḳ̣̣̂̄̄ & $\begin{array}{l}\text { Yolı sābıklaruñ bīgāneliḳdür } \\
\text { Belī ‘āşıḳlaruñ dīvāneliḳdür }\end{array}$ & $\begin{array}{l}\text { Ḳo telvīni Ḥaḳīḳi ehl-i temkīn } \\
\text { İşi tekmīl-ile şāhāneliḳdür }\end{array}$ & gazel/ 9 & ilahi & $\begin{array}{l}--- \\
\text { /.--- } \\
\text { /.-- }\end{array}$ & Velehü Eyżan \\
\hline $6 a$ & Ḥaḳ̣̣̂̄̄ & $\begin{array}{l}\text { Pertevinden hüsnünüũ gün gibi tābāndur } \\
\text { göñül } \\
\text { Çün felek rāh-1 țalebde gerçi gerdāndur gönül }\end{array}$ & 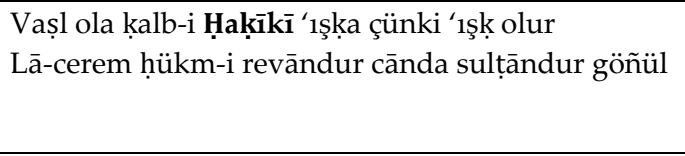 & gazel/ 10 & ilahi & $\begin{array}{l}.-- \\
1-.-- \\
1-.-- \\
1-.-\end{array}$ & $\begin{array}{l}\text { Velehü Eyżan } \\
\text { Kuddise } \\
\text { Sirruhu }\end{array}$ \\
\hline $6 b$ & Ḥaḳịḳ̄ & $\begin{array}{l}\text { Sen bana gösterme rāh-1 Ka‘be vü puthāneyi } \\
\text { Ḳomışam öz ehline men mescid ü meyhāneyi }{ }^{38}\end{array}$ & 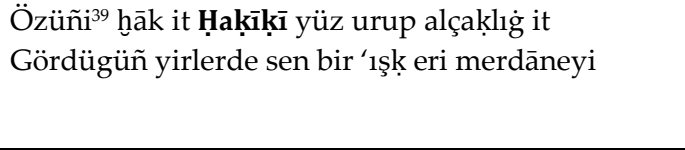 & gazel/ 9 & ilahi & $\begin{array}{l}-.-- \\
1-.-- \\
1-.-- \\
1-.-\end{array}$ & $\begin{array}{l}\text { Hִaḳị̣ị Rāst } \\
\text { Ravvahạallāhu } \\
\text { Rūḥahü'l ‘Azīz }\end{array}$ \\
\hline $7 \mathrm{~b}$ & $\begin{array}{l}\text { Cemāl-i } \\
\text { Halvetī }\end{array}$ & $\begin{array}{l}\text { Yārānlar mezheb-i '1şḳı dutup geçdüm } \\
\text { imānumdan } \\
\text { Küfür baḥrine garḳ oldum berī oldum } \\
\text { gümānumdan }\end{array}$ & $\begin{array}{l}\text { Cemāl-i Halvetĩ suhte țarīḳ-i ‘ş̧̧̧da cānuñ vir } \\
\text { Dime cāhillere sözüñ ki geçmez ol ‘ayānumdan }\end{array}$ & gazel/ 7 & ilahi & $\begin{array}{l}.-- \\
\text { /.--- } \\
\text { /.--- } \\
\end{array}$ & $\begin{array}{l}\text { Cemāl-i Halvetī̄ } \\
\text { Rāst } \\
\text { Ḳaddesallāhu } \\
\text { Rūḥahü'l-Azīz } \\
\end{array}$ \\
\hline
\end{tabular}

${ }^{34}$ ḳasr: faḳr (Yavuz, 2016, s. 742). [Mana açısından Divan'daki uygundur.]

35 dergāh-1 sultān: dergāh u eyvān (Yavuz, 2016, s. 742).

${ }^{36}$ Eksiklik Divan'dan tamamlandı (Yavuz, 2016, s. 742).

37 iy Muhibbī yār elinden: yār elinden iy Muhibbī (Yavuz, 2016, s. 742).

38 mescid ü meyhāneyi: mescid-i meyhāneyi (Boz, 2017, s. 819). [Mana açısından Mecmua'daki uygundur.]

39 özüñi: yüzüñi (Boz, 2017, s. 819).

SEFAD, 2020; (44): 213-250 
232

\begin{tabular}{|c|c|c|c|c|c|c|c|}
\hline $7 \mathrm{~b}$ & $\begin{array}{l}\text { [Cemāl-i } \\
\text { Halvetī] }\end{array}$ & $\begin{array}{l}\text { Cān-ile cānān ilinden gelmişem } \\
\text { Cān-ile sulțān ilinden gelmişem }\end{array}$ & $\begin{array}{l}\text { Cehl-i zuulmetden berīyem işidüñ } \\
\text { Nūr-ile 'irfān ilinden gelmişem }\end{array}$ & gazel/ 5 & ilahi & $\begin{array}{l}-.- \\
\text { /-.-- } \\
\text { /-.- }\end{array}$ & $\begin{array}{l}\text { Velehü Eyżan/ } \\
\text { Başlıktan } \\
\text { anlaşıldığı } \\
\text { üzere bu şiirin } \\
\text { önceki şiirin } \\
\text { şairine yani } \\
\text { Cemāl-i } \\
\text { Halvetì'ye ait } \\
\text { olma ihtimali } \\
\text { yüksektir. }\end{array}$ \\
\hline $8 \mathrm{a}$ & Ḥaḳīḳī & 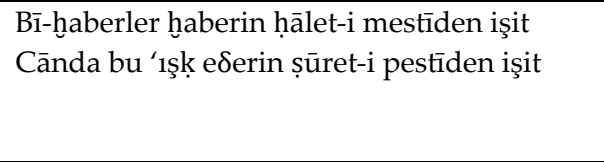 & $\begin{array}{l}\text { Ehl-i ḥāl añlaya bu remzi Ḥaḳīkīi aña dir } \\
\text { Gel beri hạalini }{ }^{40} \text { mest-i elestīden işit }\end{array}$ & gazel/ 7 & ilahi & $\begin{array}{l}. .-- \\
\text { /..-- } \\
\text { /..-- } \\
\text { /..- }\end{array}$ & $\begin{array}{l}\text { Mevlānā Ḥaḳ̄ị̄ị } \\
\text { Rāst 'Aleyhi'r- } \\
\text { raḥmetü ve'r- } \\
\text { Riḍvān }\end{array}$ \\
\hline $\begin{array}{l}- \\
\\
8 b^{41}\end{array}$ & Ḥarīmī & $\begin{array}{l}\text { Gözlerüm hūn-āb aḳıdur olalı giryān-1 hū } \\
\text { Bağrumı yaḳsa 'aceb mi āteş-i sūzān-ı hū }\end{array}$ & $\begin{array}{l}\text { İy Ḥarīmī 'ārif-isen yola țog̉rul yola gel } \\
\text { Murḡ-1 cān pervāz idüp irişmedin fermān-1 hū } \\
\text { Bir şehüñ dergāhına țut yüzini kim 'āḳıbet } \\
\text { Virmeye hayret saña tā țurıcaḳ dīvān-ı hū }\end{array}$ & kaside/ 16 & ilahi & $\begin{array}{l}-.- \\
\text { /-.-- } \\
\text { /-.-- } \\
\text { /-.- }\end{array}$ & $\begin{array}{l}\text { Kașīde-i Harāimī̄ } \\
\text { Rāst } \\
\text { Nevvarallāhu } \\
\text { Kabrehu }\end{array}$ \\
\hline $\begin{array}{l}- \\
\\
9 b\end{array}$ & Ḥarìmī & $\begin{array}{l}\text { Çün şarāb-1 'sşk-1la ser-mest idüpdür cānı hū } \\
\text { Cān içinde cānum oldur cānumuñ cānānı hū }\end{array}$ & $\begin{array}{l}\text { İy Ḥarīmī gam yime kim ḳudretin ižhār idüp } \\
\text { İüşür sen bī-nevā mücrim ḳula ihsānı hū } \\
\text { Ṭoğnı yoldan beni ırmaya dilerim tā ebed } \\
\text { Göñlüme ilhām olup her dem-be-dem bürhān-ı hū }\end{array}$ & kaside/ 27 & $\begin{array}{l}\text { tevhi } \\
\text { d }\end{array}$ & $\begin{array}{l}-.-- \\
\text { /-.-- } \\
\text { /-.-- } \\
\text { /-.- }\end{array}$ & $\begin{array}{l}\text { Kașīde-i Ḥarīmì } \\
\text { fi't-Tevḥìd }\end{array}$ \\
\hline $10 a / 11 a$ & Ḥaḳīḳ̄ & $\begin{array}{l}\text { Menem ki böyle }{ }^{42} \text { merdāne geldüm } \\
\text { Bugün baş oynaram meydāna geldüm }\end{array}$ & $\begin{array}{l}\text { Hakạị̄ì mest-i mánī oldı cān dil } \\
\text { Anın bu mahfile mestāne geldüm }\end{array}$ & kaside/ 19 & ilahi & $\begin{array}{l}.-- \\
\text { l.--- } \\
\text { /.-- }\end{array}$ & $\begin{array}{l}\text { Kașīde-i Hakịị̄ị } \\
\text { Rāst } \\
\text { Ravvahallāhu } \\
\text { Rūhahü'l-'Azīz }\end{array}$ \\
\hline $11 a / 12 a$ & Hakịị̄ì & 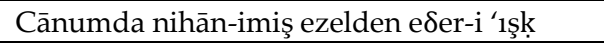 & Bì-yesme'u sem'-ile ${ }^{43}$ olan müstemi' añlar & gazel/ 9 & ilahi &.$-- / .-$ & Eyżan Lehü \\
\hline
\end{tabular}

40 hāāini: hạāl dilin (Boz, 2017, s. 164). [Vezin açısından Divan'daki uygundur.]

${ }^{41} 8$ a'dan sonraki varak 9 olarak numaralandırılması gerekirken atlanmış ve bir sonraki varağa 9 yazılmıştır. Bu kaymadan dolayı bundan sonraki varaklar varak sayısını doğru vermek adına tarafımızdan yeniden numaralandırılmış ve ilk olarak varakta yazan yanlış numara sonra doğru numara yazılmıştır.

${ }^{42}$ böyle: bu yola (Boz, 2017, s. 594). [Vezin ve mana açısından Divan'daki uygundur.]

43 Burada şu hadis-i kudsiden iktibas yapılmıştır: "İzâ ahbebte abden küntü lehû sem'an ve basar'en ve lisânen ve yed'en fe bî yesmeû ve bî yentiku ve bî yebtışü: Gönül evini benden başkasına açmayan kulumun söyleyen dili, ișiten kulağı, gören gözü ve elinden tutan Ben olurum. O kiși Ben'imle söyler, Ben'imle işitir, Ben'imle görür, ve tuttuğu işi Ben'imle tutar." (Buhârî, Rikak, 38; İbn-i Mâce, Fiten, 16.) 


\begin{tabular}{|c|c|c|c|c|c|c|c|}
\hline & & Ki oldı 'ayān dilde bu sūz-1 şerer-i '1şk & Ki remz-i Ḥaḳīḳi $\left[\right.$ de] ${ }^{44}$ ne dindi haber-i 'işḳ & & & $\begin{array}{ll}-/ .-- \\
. /--\end{array}$ & $\begin{array}{l}\text { Der-Beyān-1 } \\
\text { Netīce-i ‘Işş̧ } \\
\text { Der-Dil-i ‘Uşşāḳ }\end{array}$ \\
\hline $11 b / 12 b$ & Hakịị̄ì & $\begin{array}{l}\text { Düşeli sevdā-yı ‘sşka uş perīşāndur göñül } \\
\text { Yanmaga yandukç̧a nār-1 şevḳe 'aţ̦āandur } \\
\text { göñül }\end{array}$ & $\begin{array}{l}\text { Buldı 'ışḳ-1la Hakạị̂̄ī çün hayāt-ı sermedī } \\
\text { Pes bașar idrāk nice ide çün cāndur göñül }\end{array}$ & gazel/ 9 & ilahi & $\begin{array}{l}-.- \\
1-.-- \\
1-.-- \\
1-.-\end{array}$ & $\begin{array}{l}\text { Eyżan Lehü } \\
\text { Ravvaḥallāhu } \\
\text { Rūḥahü'l ‘Azīz }\end{array}$ \\
\hline $12 b / 13 b$ & Ḥaḳīḳ̄ & $\begin{array}{l}\text { Menem pervāne-i şem'-i dil-efrūz } \\
\text { Ki ‘ömrümdür menüm bu āteş ü sūz }\end{array}$ & $\begin{array}{l}\text { Ḳamu deryā-yı 'sşḳun cūşişidür } \\
\text { Ḥaḳīḳī bil işit eyü vü yavuz }\end{array}$ & gazel/ 7 & ilahi & $\begin{array}{l}--- \\
\text { 1.-- } \\
\text { l.-- }\end{array}$ & $\begin{array}{l}\text { Eyżan Velehü } \\
\text { Kuuddise } \\
\text { Sirruhu }\end{array}$ \\
\hline $12 b / 13 b$ & Hakịị̄ì & $\begin{array}{l}{\left[\mathrm{Uş}^{45}\right]^{5} \text { biḥamdi'llāh yitişdi vașl-1 tiryāḳı bugün }} \\
\text { Aggdı tahta tāc-1 devlet urunup baḥt-1 cüvān }{ }^{46}\end{array}$ & $\begin{array}{l}\text { 'Işḳ odı ḳıldı müdāvā tā Ḥaḳị̣̄i derdine } \\
\text { Cümle-i ḩuzzāḳuñ oldı nūr-ı ạ̣dāḳı bugün }\end{array}$ & gazel/ 6 & ilahi & $\begin{array}{l}--.- \\
1-.-- \\
1-.-- \\
1-.-\end{array}$ & $\begin{array}{l}\text { Ḥakīīin Rāst } \\
\text { Kuddise } \\
\text { Sirruhu }\end{array}$ \\
\hline $13 a / 14 a$ & Hakịị̄ì & $\begin{array}{l}\text { Yolı sābıḳlaruñ bīgāneliḳdür } \\
\text { Belī ‘āşıḳlaruñ dīvāneliḳdür }\end{array}$ & $\begin{array}{l}\text { Ko telvīni Ḥaḳīkīi ehl-i temkīn } \\
\text { İşi tekmīl-ile şāhāneliḳdür }\end{array}$ & gazel/ 9 & ilahi & $\begin{array}{l}.-- \\
\text { l.--- } \\
\text { l.-- }\end{array}$ & $\begin{array}{l}\text { Hakīkī Rāst } \\
\text { Kudddise } \\
\text { Sirruhu/ Bu şiir } \\
\text { ile 5b'deki şiir } \\
\text { mükerrerdir. }\end{array}$ \\
\hline $13 b / 14 b$ & Ḥakịị̄ì & $\begin{array}{l}\text { Pertevinden hüsnüñün gün gibi tābāndur } \\
\text { gönül } \\
\text { Çün felek rāh-1 țalebde gerçi gerdāndur gönül }\end{array}$ & 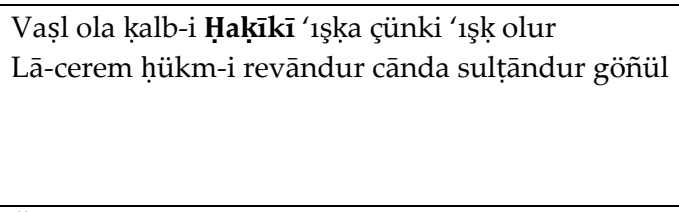 & gazel/ 10 & ilahi & $\begin{array}{l}--.- \\
\text { /-.-- } \\
\text { /-.-- } \\
\text { /-.- }\end{array}$ & $\begin{array}{l}\text { Hakīikī Rāst } \\
\text { Ḳuddise } \\
\text { Sırruhu/ Bu şiir } \\
\text { ile 6a'daki şiir } \\
\text { mükerrerdir. }\end{array}$ \\
\hline $14 b / 15 b$ & Ḥaḳīḳ̄ & $\begin{array}{l}\text { Sen baña gösterme rāh-1 Ka'be vü büthhāneyi } \\
\text { Ḳomışam öz ehline men mescid ü meyhāneyi }\end{array}$ & 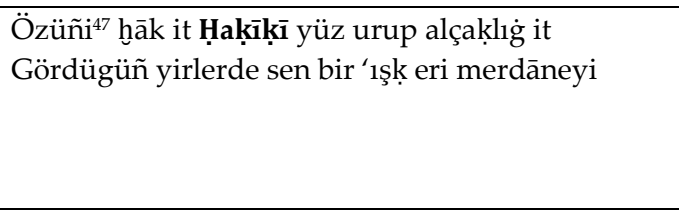 & gazel/ 9 & ilahi & $\begin{array}{l}-.- \\
1-.-- \\
1-.-- \\
1-.-\end{array}$ & $\begin{array}{l}\text { Başlık: Haḳ̄ikī } \\
\text { Rāst Kudddise } \\
\text { Sırruhu/ Bu şiir } \\
\text { ile 6b'deki şiir } \\
\text { mükerrerdir. }\end{array}$ \\
\hline
\end{tabular}

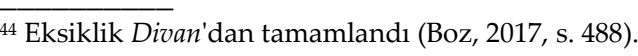

${ }^{45}$ Eksiklik Divan'dan tamamlandı (Boz, 2017, s. 656).

${ }^{46}$ Bu beyit Divan'daki 7 ve 8. beyitlerin ilk misralarıdır (Boz, 2017, s. 656).

${ }^{47}$ Özüñi: yüzüñi (Boz, 2017, s. 819).

SEFAD, 2020; (44): 213-250 


\begin{tabular}{|c|c|c|c|c|c|c|c|}
\hline $15 a / 16 a$ & Hakịīḳ̄ & $\begin{array}{l}\text { Yaġmaya virüp hānümān men 'işḳ-1 cānān } \\
\text { mestiyem } \\
\text { Terk itmişemdür 'aḳl u cān men 'işḳ-1 cānān } \\
\text { mestiyem }\end{array}$ & $\begin{array}{l}\text { Çün şu'le-i nūr-ı Ehad irdi Ḥaḳịị̄ye meded } \\
\text { Bil ki ezelden tā ebed men 'sşḳ-1 cānān mestiyem }\end{array}$ & $\begin{array}{l}\text { gazel-i } \\
\text { mutavvel/ } \\
19\end{array}$ & ilahi & $\begin{array}{l}-.- \\
--.- \\
1-.- \\
1--.-\end{array}$ & $\begin{array}{l}\text { Ḥakīkī Rāst } \\
\text { Kuddise } \\
\text { Sirruhu Der- } \\
\text { Sekr }\end{array}$ \\
\hline $16 b / 17 b$ & Ḥaḳīḳī & $\begin{array}{l}\text { Men ḩ̃āce mest-i hażretem peymāne n'olur } \\
\text { bilmezem } \\
\text { Men şem'-i nūr-1 vaḥdetem pervāne n'olur } \\
\text { bilmezem }\end{array}$ & $\begin{array}{l}\text { Cān u cihān terki bugün sehl-id[i] }{ }^{49} \text { lāyıḳ lāki bu } \\
\text { ‘Işḳuñ Ḥaḳīḳi şükrine şükrāne n'olur bilmezem }\end{array}$ & gazel/ 7 & ilahi & $\begin{array}{l}-.- \\
--.- \\
/--.- \\
/-.--\end{array}$ & Eyżan Lehü İżāf \\
\hline $17 b / 18 b$ & Yūnus & $\begin{array}{l}\text { Dāyim(ā) ene'l-Hak söyledüm Haḳdan çü } \\
\text { Manșūr olmışam } \\
\text { Kimdür beni berdār iden 'ālemde meşhūr } \\
\text { olmışam }\end{array}$ & $\begin{array}{l}\text { Yūnus odına 'işkıınuñ biñ kez yanarsa her nefes } \\
\text { Ġam yimezem çünkim senüñ luṭfuñla maḡrūr } \\
\text { olmışam }^{50}\end{array}$ & gazel/ 7 & ilahi & $\begin{array}{l}-.- \\
1--.- \\
1--.- \\
1--.-\end{array}$ & $\begin{array}{l}\text { Mevlānā Yūnus } \\
\text { Rāst } \\
\text { Ravvahạallāhu } \\
\text { Rūḥahü'l ‘Azīz }\end{array}$ \\
\hline $18 a / 19 a$ & Nesīmī & $\begin{array}{l}\text { Dünyā çün murdārdur yigren göñül } \\
\text { murdārdan } \\
\text { Gül degül dünyā dikendür (di) ne umarsun } \\
\text { hārdan }\end{array}$ & $\begin{array}{l}\text { Çün Nesīmī zāhidüñ hāālini bildi kim nedür } \\
\text { Meyden ikrāh eyleyen }{ }^{51} \text { gāafil degül hammārdan }\end{array}$ & gazel/ 7 & ilahi & $\begin{array}{l}--- \\
1-.-- \\
1-.-- \\
1-.-\end{array}$ & $\begin{array}{l}\text { Mevlānā Seyyid } \\
\text { Ḥüseyin Rāst } \\
\text { Kuddise } \\
\text { Sirruhu }\end{array}$ \\
\hline $18 b / 19 b$ & 'Āşı̣ Paşa & $\begin{array}{l}\text { Cemālüñ pertevi iy dōst ṣalalı nūr-1 envārı } \\
\text { Olup Mecnūn-veş hayayān ḳıluram nāle vü zarı }\end{array}$ & $\begin{array}{l}\text { Bu yola cān viren 'Āşıḳ 'amel ḳıla Ḥaḳa lāyık } \\
\text { Şarāb-1 lem-yezel içün temāşā ḳıl bu deryāyı }\end{array}$ & gazel/ 6 & ilahi & $\begin{array}{l}.--- \\
\text { /.--- } \\
\text { /.--- }\end{array}$ & $\begin{array}{l}\text { 'Āşık Pāşā Rāst } \\
\text { Ravvahallāhu } \\
\text { Te'ālā Rūḥahü'l } \\
\text { 'Azīz }\end{array}$ \\
\hline $19 a / 20 a$ & Nesīmī & $\begin{array}{l}\text { Derde müştāk olmayan kimdür ki dermān } \\
\text { isteye } \\
\text { Kabl-i mevti bilmeyen sen șanma kim cān } \\
\text { isteye }\end{array}$ & $\begin{array}{l}\text { Șaçinuñ̃ }^{52} \text { küfrinini }{ }^{53} \text { gerçij }^{54} \text { ehl-i fażl ìmān bilür } \\
\text { İy Nesīmī șanma sen kim kāfir īmān isteye }\end{array}$ & gazel/ 7 & ilahi & $\begin{array}{l}---- \\
\text { /-.-- } \\
\text { /-.-- } \\
\text { /-.- }\end{array}$ & $\begin{array}{l}\text { Hüuseyin Rāst } \\
\text { Ḳuddise } \\
\text { Sirruhu }\end{array}$ \\
\hline $19 b / 20 b$ & - & $\begin{array}{l}\text { Ța'ne virmeñ bize kim [biz] 'işḳa virdük } \\
\text { varumuz } \\
\text { Oda yansun işbu yolda nāmus-ile 'ārumuz }\end{array}$ & $\begin{array}{l}\text { Ḳanı bülbüller ki virem gül ḳoḳusundan ḩaber } \\
\text { Ḳarga-țab' olanlara lāyıḳ degül gülzārumuz }\end{array}$ & gazel/ 8 & ilahi & $\begin{array}{l}\text {-.-- } \\
\text { /-.-- } \\
\text { /-.-- } \\
\text { l-.- }\end{array}$ & Li-ġayrihi \\
\hline
\end{tabular}

${ }^{48}$ Mecmuada "sükr" şeklinde harekelenmiş olsa da mana açısından "sekr: sarhoş" olarak okunması uygundur.

${ }^{49}$ Eksiklik Divan'dan tamamland1 (Boz, 2017, s. 588).

${ }^{50}$ Bu gazel Yūnus Emre Divanı'nda bulunamamıștır. (Tatcı, 2008) Ancak Nesīmī Divani'nda aynı redifli ve mecmuadakinin ilk dört beytiyle aynı olan bir gazele rastlanmıștır (Ayan, 1990, s. 228). Bu duruma makalenin inceleme kısmında ayrıca değinilmiştir.

${ }^{51}$ eyleyen: eylemez (Ayan, 1990, s. 259). [Mana açısından Divan'daki uygundur.]

52 șaçınuñ: zülfünüñ (Ayan, 1990, s. 320).

53 küfrini: küfrün (Ayan, 1990, s. 320).

${ }^{54}$ gerçi: egerçi (Ayan, 1990, s. 320). 


\begin{tabular}{|c|c|c|c|c|c|c|c|}
\hline $20 a / 21 a$ & 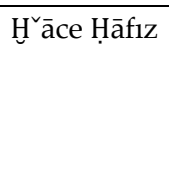 & 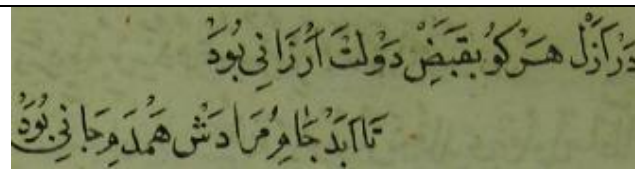 & 4 & gazel/ 7 & ilahi & $\begin{array}{l}-.- \\
1-.-- \\
1-.-- \\
1-.-\end{array}$ & $\begin{array}{l}\text { H`āce Hāfaz Rāst } \\
\text { 'Aleyhi'r- } \\
\text { Raḥmetü ve'r- } \\
\text { Rıḍvān }\end{array}$ \\
\hline $21 a / 22 a$ & 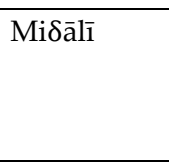 & $\begin{array}{l}\text { Cenāb-1 Ḥakḳa hilḳatden irerse seyrini sālik } \\
\text { Gözine Ḥaḳ olur hāyil o vaḳtin halḳ a'mādur }\end{array}$ & 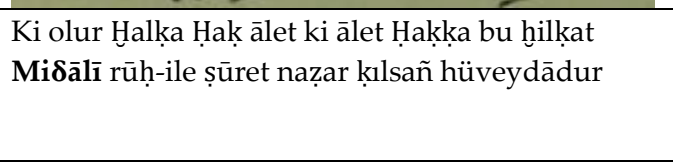 & gazel/ 12 & ilahi & $\begin{array}{l}.--- \\
\text { 1.-- } \\
\text { /.-- } \\
\text { l.--- }\end{array}$ & Şi'ir Li-ġayrihi \\
\hline $21 b / 22 b$ & Nesīmī & $\begin{array}{l}\text { Ḳanı bir ‘ahd u peymānı bütün yār } \\
\text { Ḳanı bir ḳavli gerçek țog̀nı dildār }\end{array}$ & $\begin{array}{l}\text { Yār-ile çün ki yār oldı Nesīm̄īis } \\
\text { Kamu 'ālem ne ġam ger olsa ag̀yār }\end{array}$ & gazel/ 12 & ilahi & $\begin{array}{l}.-- \\
\text { I.--- } \\
\text { I.-- }\end{array}$ & $\begin{array}{l}\text { Mevlānā Seyyid } \\
\text { Hüseyin Rāst } \\
\text { Sirru'l 'Azīz }\end{array}$ \\
\hline $22 b / 23 b$ & Nesīmī & $\begin{array}{l}\text { Cānda ki ‘ş̧̧ olmadi }{ }^{56} \text { dilde haber ne fāyide } \\
\text { Gözde ki görmek olmadı }{ }^{57} \text { nūr-1 baṣar ne } \\
\text { fāyide }\end{array}$ & 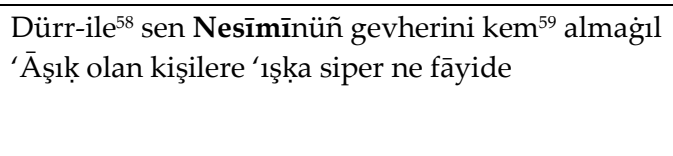 & gazel/ 5 & ilahi & $\begin{array}{l}-. .- \\
1 .-.- \\
1-. .- \\
1 .-.-\end{array}$ & Eyżan Lehü \\
\hline $23 a / 24 a$ & Nesīmī & Her kim ${ }^{60}$ aldandı cihānuñ aġılu lezzzātına & Çün cemālüñden Nesīmī ebcedi ḳıldı tamām & gazel/ 11 & ilahi &.--- & Eyżan Lehü \\
\hline
\end{tabular}

55 yār-ile çün ki yār oldı Nesīmī: Nesīmī yār ilen çün yār oldu (Ayan, 1990, s. 144).

56 olmadi: olmasa (Ayan, 1990, s. 297).

${ }^{57}$ olmadi: olmasa (Ayan, 1990, s. 297).

58 dürr-ile: derd ile (Ayan, 1990, s. 297). [Mana açısından Mecmua'daki uygundur.]

59 kem: kim (Ayan, 1990, s. 297). [Mana açısından Mecmua'daki uygundur.]

${ }^{60}$ her kim: kim ki (Ayan, 1990, s. 300).

SEFAD, 2020; (44): 213-250 
236

\begin{tabular}{|c|c|c|c|c|c|c|c|}
\hline & & $\begin{array}{l}\text { Düşdi şol menșūbesi çoḳ dünyenüñ şeh } \\
\text { matına }\end{array}$ & 'Ayn-1 mīmüñ ‘ammesinden irdi ve's-säffätına ${ }^{61}$ & & & $\begin{array}{l}1-.- \\
1-.-- \\
1-.-\end{array}$ & \\
\hline $24 a / 25 a$ & Nesīmī & $\begin{array}{l}\text { Yedd-i beyżādur vücūduñ Hạ nişānı } \\
\text { sendedür }{ }^{62} \\
\text { Zāāhir ü bāṭn çü sensin }[\mathrm{bes}]^{63} \text { ḳalanı ḳandadur }\end{array}$ & $\begin{array}{l}\text { Çün Nesīmī sırr-1 İbrāhīm Ḥaşşimdür }{ }^{64} \text { bugün } \\
\text { Ḥaḳḳa vāṣıldur bugün kim cān cānı ḳandadurr }\end{array}$ & kaside/ 9 & naat & $\begin{array}{l}\text { l-.-- } \\
\text { /-.-- } \\
\text { /-.- }\end{array}$ & $\begin{array}{l}\text { Eyżan Lehü } \\
\text { Der-Na't-1 } \\
\text { Resūlullāh } \\
\text { Sallallāhu } \\
\text { 'Aleyhi } \\
\text { Vesellem }\end{array}$ \\
\hline $24 b / 25 b$ & Nesīmī & $\begin{array}{l}\begin{array}{l}\text { El-minnetüli'llāh ki bugün yārümi buldum } \\
\text { Göñlümde } \\
\text { buldum }\end{array} \text { gezen }{ }^{66} \text { dilber-i dildārumi }{ }^{67} \\
\end{array}$ & $\begin{array}{l}\text { Virdi șaçınuñ küfrine īmānı Nesīmī } \\
\text { İy hırḳa giyen ben dahıı zünnārumı buldum }\end{array}$ & gazel/ 13 & ilahi & $\begin{array}{l}-. / .- \\
-. / .-- \\
. / .-- \\
\end{array}$ & Velehü Eyżan \\
\hline $26 a / 27 a$ & Nesīmī & $\begin{array}{l}\text { ‘Āşsı ḳatında küfr-ile İslām birdürr68 } \\
\text { Her ḳanda mesken eylese ‘asşı̣ emīrdür }\end{array}$ & $\begin{array}{l}\text { Ṭarh eyledi yoluñda Nesīmī vücūdını } \\
\text { Gör kim anı }{ }^{69} \text { ne muḥteşem olmış faḳirdür }\end{array}$ & gazel/ 12 & ilahi & $\begin{array}{l}--. /- \\
--. / .- \\
-. /-.-\end{array}$ & Velehü Eyżan \\
\hline $27 a / 28 a$ & Nesīmī & $\begin{array}{l}\text { Sendedür ol genc-i pinhān gezme her vīrāne'i } \\
\text { Deñize țalandan }{ }^{70} \text { iste iy gönüul dür-dāne'i }\end{array}$ & $\begin{array}{l}\text { Çün makālìdü's-semāoāt }{ }^{71} \text { iy Nesīmī sendedür } \\
\text { Kạa u lāmuñdan götürdi sīn ü şīn u dāne' }{ }^{72}\end{array}$ & gazel/ 12 & ilahi & $\begin{array}{l}-.-- \\
\text { /-.-- } \\
\text { /-.-- } \\
\text { /-.- }\end{array}$ & Velehü Eyżan \\
\hline $27 \mathrm{~b} / 28 \mathrm{~b}$ & Nesīmī & $\begin{array}{l}\text { ‘Ālemde bugün ‘ahdı bütün yār ele girmez } \\
\text { Yandurdı diken bağrumı gülzār ele girmez }\end{array}$ & $\begin{array}{l}\text { Elfāż-1 Nesīmī bugün ol }{ }^{13} \text { mu'cizedür kim } \\
\text { Beñzer aña bir lü'lü-i şehvār ele girmez }\end{array}$ & gazel/ 11 & ilahi & $\begin{array}{l}-. / .- \\
-. / .- \\
. / .--\end{array}$ & Velehü Eyżan \\
\hline
\end{tabular}

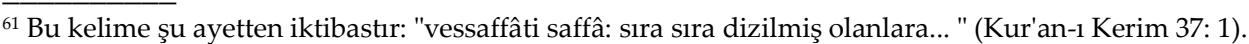

${ }^{62}$ sendedür: ḳandadır (Ayan, 1990, s. 148). [Mana açısından Mecmua'daki uygundur.]

${ }^{63}$ Eksiklik Divan'dan tamamlandı. (Ayan, 1990, s. 148).

64 İbrāhīm Hāșimdür/ İbrāhīm ü Hāşimdir (Ayan, 1990, s. 148).

${ }^{65}$ Ḥaḳḳa vāṣıldur bugün kim cān cānı: ger Ḥaḳa vāsıl oluptur cism ü cānı (Ayan, 1990, s. 148). [Mana açısından Divan'daki uygundur.]

${ }^{66}$ gezen: duran (Ayan, 1990, s. 243).

${ }^{67}$ dilber-i dildārumı: dilber ü dildārımı (Ayan, 1990, s. 243). [Mana açısından Divan'daki uygundur.]

${ }^{68}$ Misra vezin açısından kusurludur.

${ }^{69}$ kim anı: anı kim (Ayan, 1990, s. 154).

70 țalandan: țal andan (Ayan, 1990, s. 357).

${ }^{11}$ Bu terkip şu ayetten iktibastır: "lehü mekâlîdü's-semâvâti ve'l-arz: göklerin ve yerin anahtarları O'nundur..." (Kur'an-1 Kerim 39: 63).

72 götürdi sīn ü s̄in u dāne'i: götürgil sīn ü şin-dendāneyi (Ayan, 1990, s. 357). [Mana açısından Divan'daki uygundur.]

${ }^{73}$ ol: el (Ayan, 1990, s. 184). [Mana açısından Mecmua'daki uygundur.] 


\begin{tabular}{|c|c|c|c|c|c|c|c|}
\hline $28 b / 29 b$ & Nesīmī & & $0,12^{2}$ & gazel/ 14 & ilahi & $?$ & Velehü Eyżan \\
\hline $29 a / 30 a$ & Cemālī & $\begin{array}{l}\text { Cefāsın ma'şūḳuñ dāyim kişi kim ihtiyār } \\
\text { itmez } \\
\text { Anuñ vașlı şarābından açup cān tārumār } \\
\text { itmez }\end{array}$ & $\begin{array}{l}\text { Cemālī cān gözine sen celālī sürmesin çekseñ } \\
\text { Görünmeyeydi gözüne ki tesyīc aña dār itmez }\end{array}$ & gazel/ 5 & ilahi & $\begin{array}{l}.--- \\
\text { /.--- } \\
\text { /.--- }\end{array}$ & $\begin{array}{l}\text { Mevlānā } \\
\text { Cemālī Rāst }\end{array}$ \\
\hline $\begin{array}{l}29 b / \\
30 b\end{array}$ & $\begin{array}{l}\text { [Cemāl-i } \\
\text { Halvetī] }\end{array}$ & $\begin{array}{l}\text { Anuñ cemālin göreli dilde ḳarārum ḳalmadı } \\
\text { Uşandı șabrum şişesi nāmūs u áarum ḳalmadı }\end{array}$ & $\begin{array}{l}\text { ‘Işḳuñ odı olur sebep açmag̉a benüm perdemi } \\
\text { Ḥālüm nice fāş olmasun çün perde-dārum ḳalmadı }\end{array}$ & gazel/ 7 & ilahi & $\begin{array}{l}-.- \\
--.- \\
1--.- \\
\text { /--.- }\end{array}$ & $\begin{array}{l}\text { Cemāl-i Hualvetī } \\
\text { Kuddise } \\
\text { Sırruhu }\end{array}$ \\
\hline $30 a / 31 a$ & $\begin{array}{ll}\text { Eşref } & \text { Og்lı } \\
\text { Rūmīi } & \end{array}$ & $\begin{array}{l}\text { Cānlar cānın ister-iseñ } \\
\text { Bu cism ü cāndan fāriğ ol } \\
\text { Gerçek ‘āşı̣ olduñ-1sa }^{74} \\
\text { İki cihāndan fārig ol }\end{array}$ & $\begin{array}{l}\text { Eşrefog̀lı Rūmīi iseñ } \\
\text { Eger gerçek er-iseñ } \\
\text { Fārig olup bu cümleden } \\
\text { Fin } \\
\text { Kevn ü mekāndan fārig ol }\end{array}$ & koşma/ 7 & ilahi & $\begin{array}{l}8^{\prime} l i \\
\text { hec } \\
\text { e }\end{array}$ & $\begin{array}{l}\text { Eşref-zāde-i } \\
\text { Rūmī Rāst } \\
\text { Ravvāḥallahu } \\
\text { Rūhahu }\end{array}$ \\
\hline $30 b / 31 b$ & Hayālī & $\begin{array}{l}\text { Hevā șahrāsı içinde dün ü gün } \\
\text { Yürürem gāh ‘ākil gāh mecnūn } \\
\text { Naẓar ḳılmaz-ise ol ferd-i bī-çūn } \\
\text { Bekā veylü feveylü Sümme veylü }\end{array}$ & $\begin{array}{l}\text { Ölüp sine giricegez Hayālī } \\
\text { Dilinde kalmaya hergiz mecāli } \\
\text { ‘Amelden ḳapıcak ben böyle ḥāli } \\
\text { Bekā veylü feveylü sümme veylü }\end{array}$ & $\begin{array}{l}\text { murabba-1 } \\
\text { mütekerri } \\
\text { r/ } 4\end{array}$ & ilahi & $\begin{array}{l}.-- \\
\text { /.-- } \\
\text { l.-- }\end{array}$ & $\begin{array}{l}\text { Hayālī } \\
\text { Fermāyed }\end{array}$ \\
\hline $31 b / 32 b$ & Kanber & $\begin{array}{l}\text { Eger iş gitdise elden ḳaçan gider hevā dilden } \\
\text { Ve ger dil ḳaldısa yolda kalur mı cān } \\
\text { menzilden }\end{array}$ & $\begin{array}{l}\text { Ḳoma zinhār iy Kanber elüñden dāmen-i Ḥayder } \\
\text { Bu yolda bil ki ol rehber geçürür cümle hāyilden }\end{array}$ & gazel/ 13 & ilahi & $\begin{array}{l}.--- \\
\text { /.--- } \\
\text { /.--- }\end{array}$ & $\begin{array}{l}\text { Kanber } \\
\text { Fermāyed } \\
\text { Nevvarrallāhu } \\
\text { Kabrehu }\end{array}$ \\
\hline $32 b / 33 b$ & İbrāhīm & $\begin{array}{l}\text { Hāle degşürdi bi-küllī kāālini dervisşler } \\
\text { Kimseye bildürmedi aḥvālini dervişler }\end{array}$ & $\begin{array}{l}\text { Hil'at ü devlet gey[ey]di şeksüz İbrāhīm eger } \\
\text { Virseler bir pāre aña şālını dervişşler }\end{array}$ & gazel/ 13 & ilahi & $\begin{array}{l}-.- \\
-.-- \\
\end{array}$ & $\begin{array}{l}\text { İbrāhīm } \\
\text { Fermāyed }\end{array}$ \\
\hline
\end{tabular}

\footnotetext{
74 ‘āşı̣ olduñ-1sa: Ḥaḳka 'āşıłk-isen (Ayan, 1990, s. 108). [Kafiye açısından Divan'daki uygundur.]

${ }^{75}$ Eşrefoğlı Rūmī-isen: Eşrefog̀lu Rūmī sen de (Ayan, 1990, s. 108).

${ }^{76}$ gerçek er-isen : gerçeklerden-isen (Ayan, 1990, s. 108).

${ }^{77}$ Fārig olup bu cümleden: Fārig ol bu cümlesinden (Ayan, 1990, s. 108).

SEFAD, 2020; (44): 213-250
} 


\begin{tabular}{|c|c|c|c|c|c|c|c|}
\hline & & & & & & $\begin{array}{l}\text { /-.-- } \\
\mid-.-\end{array}$ & $\begin{array}{l}\text { Nevvarrallāhu } \\
\text { Kabrehu }\end{array}$ \\
\hline $33 b / 34 b$ & İbrāhīm & $\begin{array}{l}\text { Ferāgat umma bī-kār olmayınca } \\
\text { Yola girme sebük-bār olmayınca }\end{array}$ & $\begin{array}{l}\text { Ṣafā olmaya İbrāhīm demüñden } \\
\text { Ki tā hem-reng ‘ațāār olmayınca } \\
\text { Gerekdür bāl ü per kim bu hevāda }{ }^{78} \\
\text { İrişmez kimse }{ }^{79} \text { Ṭayyār olmayınca }\end{array}$ & kaside/ 34 & ilahi & $\begin{array}{l}.--- \\
\text { /.--- } \\
\text { /.-- }\end{array}$ & $\begin{array}{l}\text { İbrāhīm } \\
\text { Fermāyed } \\
\text { Nevvarrallāhu } \\
\text { Ḳabrehu }\end{array}$ \\
\hline $36 a / 37 a$ & İbrāhīm & $\begin{array}{l}\text { Hiçe șay göz ki kan degül yaşı } \\
\text { Dahıı sevdāsı olmayan başı }\end{array}$ & $\begin{array}{l}\text { ‘Işḳa sen yār șanma İbrāhīm } \\
\text { Degme bir bī-vefā ḳulmaşı }{ }^{80} \\
\text { Țaşa beñzetme münkirüñ göñlin } \\
\text { Kişi sa'y-ile yumşadur țaşı }\end{array}$ & $\begin{array}{l}\text { terci-i } \\
\text { bend }^{81} / 13\end{array}$ & ilahi & $\begin{array}{l}\text {..-- } \\
\text { /.-.- } \\
\text { /..- }\end{array}$ & $\begin{array}{l}\text { İbrāhīm } \\
\text { Fermāyed }\end{array}$ \\
\hline $37 a / 38 a$ & İbrāhīm & $\begin{array}{l}\text { Göñül sen puhte olġıl kim begenmez puhteler } \\
\text { hāamı } \\
\text { Dilerseñ 'ışk elinden cām oda yaḳ dāne }{ }^{82} \text { vü } \\
\text { damı }\end{array}$ & 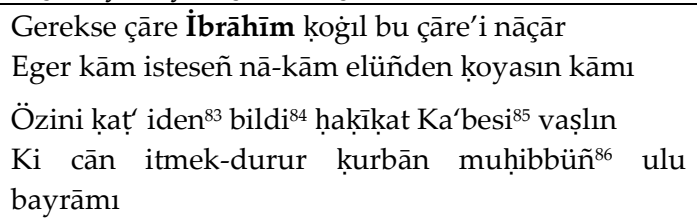 & gazel/ 11 & ilahi & $\begin{array}{l}.-- \\
\text { /.--- } \\
\text { /.--- }\end{array}$ & $\begin{array}{l}\text { İbrāhīm } \\
\text { Fermāyed }\end{array}$ \\
\hline $\begin{array}{l}31 \mathrm{a} / \\
39 a^{87}\end{array}$ & İbrāhīm & $\begin{array}{l}\text { Bīgāne dimeñ }{ }^{88} \text { aña ki 'ışḳ āşināāıdur } \\
\text { 'Işḳuñ kim olsa çākeri begler gedāsıdur }\end{array}$ & 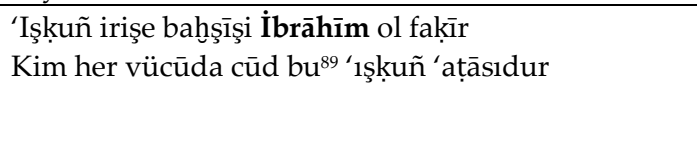 & gazel/ 11 & ilahi & $\begin{array}{l}-. /- \\
-. / .- \\
-. /-.-\end{array}$ & $\begin{array}{l}\text { İbrāhīm } \\
\text { Fermāyed } \\
\text { Nevvarrallāhu } \\
\text { Kabrehu }\end{array}$ \\
\hline $32 a / 40 a$ & $\begin{array}{l}\text { Muhliṣ Og்lı } \\
\text { Paşa }\end{array}$ & $\begin{array}{l}\text { Her ki baña ag̉yār-ise } \\
\text { Ḥaḳ Tañrı yār olsun aña }\end{array}$ & $\begin{array}{l}\text { Bu Muhliss Oġlı Pāşānuñ } \\
\text { Güldügini istemeyen }\end{array}$ & koşma/ 7 & ilahi & $\begin{array}{l}\text { 8'li } \\
\text { hec }\end{array}$ & $\begin{array}{l}\text { Og̉lı Pāşā } \\
\text { Fermāyed }\end{array}$ \\
\hline
\end{tabular}

${ }^{78}$ hevāda: hevāya (Bağçeci \& Deniz, 2019, s. 221).

79 kimse: kimesne (Bağçeci \& Deniz, 2019, s. 221). [Vezin açısından Mecmua'daki uygundur.]

80 ḳulmaşı: ḳılmayışı (Bağçeci \& Deniz, 2019, s. 238). [Mana açısından Mecmua'daki uygundur.]

${ }^{81}$ Bu manzume Divan'daki bir terci-i bendin 6. bendidir. (Bağçeci \& Deniz, 2019, s. 238).

82 dāne: neng (Bağçeci \& Deniz, 2019, s. 247). [Mana açısından Mecmua'daki uygundur.]

83 iden: idüp (Bağçeci \& Deniz, 2019, s. 247).

${ }^{84}$ bildi: buldu (Bağçeci \& Deniz, 2019, s. 247). [Mana açısından Mecmua'daki uygundur.]

${ }^{85}$ Ka'besi: Ka'beyi (Bağçeci \& Deniz, 2019, s. 247). [Mana açısından Mecmua'daki uygundur.]

${ }^{86}$ muhibbüñ̃: muhannnik (Bağçeci \& Deniz, 2019, s. 247). [Mana açısından Mecmua'daki uygundur.]

87 Mecmuanın numaralandırılmasında 37a'dan sonra bu varağa 38 yazılması gerekirken sehven 31 olarak numara verilmiş ve sonraki varaklar da bu nedenle kaymış̧ır. Bu kısımdan önce de 8 b'deki dipnotta belirtildiği üzere numaralandırmada daha önce bir kayma daha olmuş ve tarafımızdan yeniden numaraladırma yapılmıştır. Mecmuanın bu varağından itibaren yine bu numaralandırmaya devam edilmiş ve ilk olarak mecmuada bulunan numara, ardından sonradan verilen numara yazılmıştır.

88 dimeñ: dimek (Bağçeci \& Deniz, 2019, s. 250). [Mana açısından Mecmua'daki uygundur.]

89 cūd bu: cūdlu (Bağçeci \& Deniz, 2019, s. 250). [Mana açısından Mecmua'daki uygundur.] 


\begin{tabular}{|c|c|c|c|c|c|c|c|}
\hline & [Āşsık Paşa] & $\begin{array}{l}\text { Her ḳançaru varur-ise } \\
\text { Bāg u u bahār olsun aña }\end{array}$ & $\begin{array}{l}\text { Agladugum isteyenüñ } \\
\text { Gözüm biñar olsun aña }\end{array}$ & & & $\mathrm{e}$ & $\begin{array}{l}\text { Nevvarrallāhu } \\
\text { Kabrehu }\end{array}$ \\
\hline $32 b / 40 b$ & Ḥarīmī & $\begin{array}{l}\text { Kanā'at umma bī-kār olmayınca } \\
\text { Ferāgat ḳılma der-kār olmayınca }\end{array}$ & $\begin{array}{l}\text { Hearīmī būy-ı vașl almaz deminden } \\
\text { Nesīm-i luțı 'ațāār olmayınca } \\
\text { Belürmez 'āşıkuñ āhı duhāāı } \\
\text { Yüregi micmeri nār olmayınca }\end{array}$ & kaside/ 35 & ilahi & $\begin{array}{l}.-- \\
\text { l.--- } \\
\text { l.-- }\end{array}$ & $\begin{array}{l}\text { Kasșīde-i Ḥarīmī } \\
\text { Rāst } \\
\text { Nevvarrallāhu } \\
\text { Kabrehu }\end{array}$ \\
\hline $\begin{array}{l}33 b / 2 k \\
41 b /\end{array}$ & Ḥayretī & $\begin{array}{l}\text { İy felek ya sen bir eføīlerle țolmış gāarsın } \\
\text { Ya yedi başlu bir ejderhā-yı merdüm-ḩ̌ārsın }\end{array}$ & $\begin{array}{l}\text { Hayretī bu dehr-i fānīde şikāyet nice bir } \\
\text { Bir iki gün ehline ıșmarla anı varsın }\end{array}$ & gazel/ 7 & ilahi & $\begin{array}{l}-.-- \\
1-.-- \\
1-.-- \\
1-.-\end{array}$ & \\
\hline $35 a / 43 a$ & Kanber & $\begin{array}{l}\text { Benüm derdüm bilen sensin irişdür aña } \\
\text { dermānı } \\
\text { Beni hạayān iden sensin ḳavuşdur cāna cānānı }\end{array}$ & $\begin{array}{l}\text { Senüñ bu derdüñi Kanber hemān yine bilür Hayder } \\
\text { Ḳo sözi gözsüz añlamaz ḩaberden şems-i tābānı } \\
\text { Gerek merdān-ı ma'nī tā bu 'işretden bula lezzzāt } \\
\text { Ne bilsün vașf-ile gaybın șafā vü zevevk merdānı }\end{array}$ & kaside/ 17 & ilahi & $\begin{array}{l}.--- \\
\text { /.-- } \\
\text { /.-- } \\
\text { /.-- }\end{array}$ & $\begin{array}{l}\text { Kasṣìde-i Ḥarīmī̄ } \\
\text { (a.s.) Raḥmetü } \\
\text { ve'r-Rıḍān/ } \\
\text { Kasidenin } \\
\text { mahlas } \\
\text { beytinde } \\
\text { Kanber, } \\
\text { başlı̆̆ında ise } \\
\text { Harīmī mahlası } \\
\text { geçmektedir. }\end{array}$ \\
\hline $36 b / 44 b$ & Ḥaḳị̄ị & $\begin{array}{l}\text { 'Işkưuñla biz }[\mathrm{bu}]^{90} \text { 'ālemüñ } \text { sevdālarından } \\
\text { fāriguz } \\
\text { Meh-rūlaruñdan hem gözi şehlālarından } \\
\text { fāriguz }\end{array}$ & $\begin{array}{l}\text { Ma'nī cemāli vireli ḳalbe Ḥaḳị̣̂ī rūşinā } \\
\text { Biz bu cihānun șūret-i zībālarından fāriğuz }\end{array}$ & gazel/ 9 & ilahi & $\begin{array}{l}-\cdot-\cdot \\
1--.- \\
1--.- \\
1--.-\end{array}$ & $\begin{array}{l}\text { Ḥakịị̄ì Rāst } \\
\text { Ravvāḥallahu } \\
\text { Rūḥahu }\end{array}$ \\
\hline $37 b / 45 b$ & Ḥaḳị̄ị & $\begin{array}{l}\text { Yine irdi ḳalbe mevc ol ḳulzüm-i āteşden uş } \\
\text { Zevraḳ-1 aḳlı virür garḳa șu aşdı başdan uş }\end{array}$ & 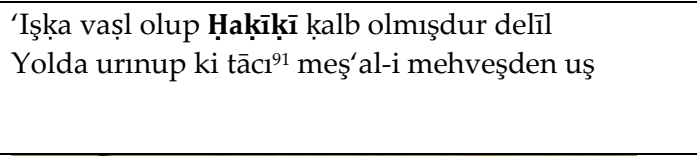 & gazel/ 5 & ilahi & $\begin{array}{l}-.- \\
1-.-- \\
1-.-- \\
1-.-\end{array}$ & $\begin{array}{l}\text { Mevlānā Ḥaḳīḳ̄ } \\
\text { Rāst E'r- } \\
\text { raḥmetü }\end{array}$ \\
\hline $37 b / 45 b$ & Ḥaḳị̄ị & İşbu șūret ālemine cān ezelden geldi mest & 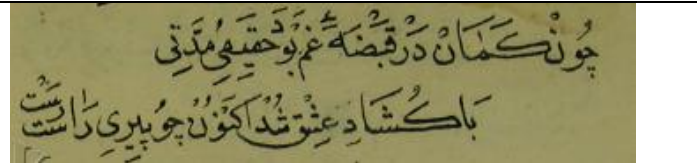 & gazel/ 9 & ilahi & $\begin{array}{l}-.-- \\
1-.-- \\
1-.-- \\
\text { /-.- }\end{array}$ & $\begin{array}{l}\text { Velehü Eyżan } \\
\text { Ķuddise } \\
\text { Sirruhu }\end{array}$ \\
\hline $38 b / 46 b$ & Ḥaḳị̄ị & Dil yine meyhāaneden irişdi mest & Ḳıldı Haḳị̄ịìyi ezelden ebed & gazel/ 7 & ilahi &..$--/-$ & Eyżan Lehü \\
\hline
\end{tabular}

90 Eksiklik Divan'dan tamamland (Boz, 2017, s. 337).

${ }^{91}$ tācı: tāc ol (Boz, 2017, s. 389).

SEFAD, 2020; (44): 213-250 


\begin{tabular}{|c|c|c|c|c|c|c|c|}
\hline & & Ḳaldı ayahda yine bu 'akl-1 pest & Mest-i Hüüā cür’a-1 bezm-i elest & & & $\begin{array}{ll}.-/- \\
.- \\
\end{array}$ & $\begin{array}{l}\text { Ravvāḥallahu } \\
\text { Rūḥahu }\end{array}$ \\
\hline $39 a / 47 a$ & Hakạiḳ̄ì & $\begin{array}{l}\text { Her zehri nūş eyleyelüm } \\
\text { Eș-șabru miftāḥü'l-ferec } \\
\text { Deryā-șıfat cūş idelüm } \\
\text { Eș-șabru miftāhü'l-ferec }\end{array}$ & $\begin{array}{l}\text { ‘Işḳa Ḥaḳīḳ̄ ne vaḳar } \\
\text { Ne șabr u ārām u ḳarār } \\
\text { Hey niçe dirsin bize var } \\
\text { Eș-șabru miftāhüül-ferec }\end{array}$ & koşma/ 11 & ilahi & $\begin{array}{l}8^{\prime} \mathrm{li} \\
\text { hec } \\
\mathrm{e}\end{array}$ & $\begin{array}{l}\text { Eyżan Lehü } \\
\text { 'Aleyhi'r- } \\
\text { Raḥmetü }\end{array}$ \\
\hline $39 b / 47 b$ & Haḳịḳ̄ & $\begin{array}{l}\text { Cāna ḳıymazsañ girüp ortaya meydān isteme } \\
\text { Başuñı țop itmeyince elde çevgān isteme }\end{array}$ & $\begin{array}{l}\text { Baṣmadın yola Ḥakịịī sen henüz evvel ḳadem } \\
\text { Bu nihāyetsiz țarīḳa ḥadd ü pāyān isteme }\end{array}$ & gazel/ 9 & ilahi & $\begin{array}{l}-.-- \\
1-.-- \\
1-.-- \\
1-.-\end{array}$ & $\begin{array}{l}\text { Eyżan Lehü } \\
\text { Raḥmetullāhi }\end{array}$ \\
\hline $40 b / 48 b$ & Hakạiḳ̄i & $\begin{array}{l}\text { Bir zerre ki Ḥaḳdan ḳula nā-gāh naẓar irdi } \\
\text { Ol bāțına yüz şu'le-i şems ü ḳamer irdi }\end{array}$ & $\begin{array}{l}\text { Çün bahr-i hakāyılk yine mevc urdı Hakịị̄ị̄ } \\
\text { Elden ḳoma ki ḳıymeti ‘ālī güher irdi }\end{array}$ & gazel/ 9 & ilahi & $\begin{array}{l}--. / .- \\
-. / .-- \\
. / .--\end{array}$ & $\begin{array}{l}\text { Velehü Eyżan } \\
\text { Der-Șafā-yı } \\
\text { Bāṭın }\end{array}$ \\
\hline $41 a / 49 a$ & Ḥaḳịk̄ì & $\begin{array}{l}\text { Olmayan 'āşıḳ ne bilsün 'ışḳ eri sevdāsını } \\
\text { Bulmayan '1şḳı ne bilsün 'āşıḳ bī-cāsını }\end{array}$ & $\begin{array}{l}\text { Derd-i hūn̄ine Ḥakīịịi țoymadı kāni’ degül } \\
\text { Cānda bulmışken anuñ bu kenz-i lā-yefnāsını }\end{array}$ & gazel/ 11 & ilahi & $\begin{array}{l}-.-- \\
1-.-- \\
1-.-- \\
1-.-\end{array}$ & $\begin{array}{l}\text { Velehü Eyżan } \\
\text { Nevvarrallāhu } \\
\text { Kabrehu }\end{array}$ \\
\hline $\begin{array}{l}41 b / 49 b \\
\text { Dk }\end{array}$ & $\begin{array}{l}\text { Abdurraḥma } \\
\mathrm{n}\end{array}$ & $\begin{array}{l}\text { Budur ki cānda nașīb olmadı } \\
\text { Buña '1şḳ dirler țog̀rı yārümdür } \\
\text { Nām u nişānına gözler irmedi } \\
\text { [Buña '1şḳ dirler țoggrı yārümdür] }\end{array}$ & $\begin{array}{l}\text { ๑Abdu'r-rahman 'sşk şem'inde } \\
\text { Anda ki ‘ahdi gelüp bunda güder } \\
\text { Bizümle geldi bile gider } \\
\text { Buña 'sşk dirler țog̀n yārümdür }\end{array}$ & koşma/ 6 & ilahi & $?$ & $\begin{array}{l}\text { Abdurraḥman } \\
\text { Fermāyed }\end{array}$ \\
\hline $42 a / 50 a$ & Ḥaḳ̣̣̂̄̄ì & $\begin{array}{l}\text { Yine bu zevraḳ-1 'aḳlı göñülden cūş iden } \\
\text { deryā } \\
\text { Virür garḳa ki hūnīndür bu emvāc u telāțum- } \\
\text { hā }\end{array}$ & $\begin{array}{l}\text { Ḥaḳị̣̂i 'sşk-1la ol mest yuyup cān u cihāndan dest } \\
\text { Yüz urup topragia ol pest bu dīn yolında çün gabrā }\end{array}$ & gazel/ 9 & ilahi & $\begin{array}{l}.--- \\
\text { /.--- } \\
\text { /.--- }\end{array}$ & $\begin{array}{l}\text { Velehü Eyżan } \\
\text { Ravvāḥallahu } \\
\text { Rūḥahu }\end{array}$ \\
\hline $\begin{array}{l}42 \mathrm{~b} / \\
50 \mathrm{~b}\end{array}$ & Hakạiḳ̄ì & $\begin{array}{l}\text { Çü țālib olmadı fānī be-küllī ‘ucb u hestīden } \\
\text { Bilüñ ḳurtulmadı anı belā-yı hod-perestīden }\end{array}$ & $\begin{array}{l}\text { ‘Aceb bu āteşīn sevdā ne cūşişdür bu ne deryā } \\
\text { Ḥaḳīḳī şevḳ u şūriş-hā gör ol mest-i elestīden }\end{array}$ & gazel/ 7 & ilahi & $\begin{array}{l}.--- \\
\text { /.--- } \\
\text { /.-- } \\
\text { 1.--- }\end{array}$ & $\begin{array}{l}\text { Eyżan Lehü } \\
\text { Der-Ṭarīk-i } \\
\text { Fenā }\end{array}$ \\
\hline $\begin{array}{l}43 \mathrm{~b} / \\
51 \mathrm{~b}\end{array}$ & Ḥayretī & $\begin{array}{l}\text { Cihānı eyledi'² '1şke-1la mevcūd } \\
\text { Zehī iḥsān zehī luțf u zehī cūd }\end{array}$ & $\begin{array}{l}\text { Șorarsa Ḥayretīen zāhid eydür } \\
\text { Hemāñ birdür hemān bir cümle mevcūd }\end{array}$ & gazel/ 9 & ilahi & $\begin{array}{l}--- \\
\text { I.--- } \\
\text { /.-- } \\
\end{array}$ & $\begin{array}{l}\text { Hayretī } \\
\text { Fermāyed }\end{array}$ \\
\hline $\begin{array}{l}43 \mathrm{~b} / \\
51 \mathrm{~b}\end{array}$ & Ḥayretī & $\begin{array}{l}\text { Rind-i fānīler bu dünyā-yı fenādan geçdiler } \\
\text { Zāhidā șanma şarāb-1 dil-güşādan geçdiler }\end{array}$ & $\begin{array}{l}\text { Țālib-i rāh-1 hakikịat oldılar abdāllar } \\
\text { Ḥayretī el yudılar her mācerādan geçdiler }\end{array}$ & gazel/ 5 & ilahi & $\begin{array}{l}-.-- \\
1-.--\end{array}$ & $\begin{array}{l}\text { Hẹayretī } \\
\text { Fermāyed }\end{array}$ \\
\hline
\end{tabular}

92 eyledi: eyledüñ (Çavuşoğlu \& Tanyeri, 1981, s. 157). 


\begin{tabular}{|c|c|c|c|c|c|c|c|}
\hline & & & & & & $\begin{array}{l}1-.- \\
1-.- \\
\end{array}$ & \\
\hline $44 a / 52 a$ & İbrāhīm & $\begin{array}{l}\text { Bugün biñ luṭ̂f-1la cānān göründi } \\
\text { Gel indi gözüñ aç iy cān göründi }\end{array}$ & $\begin{array}{l}\text { Bu İbrāhīme beñzer kemterīn kul } \\
\text { Kemīne mübtelā ḳandan göründi }\end{array}$ & gazel/ 9 & ilahi & $\begin{array}{l}.-- \\
\text { l.-- } \\
\text { l.-- }\end{array}$ & $\begin{array}{l}\text { İbrāhīm } \\
\text { Fermāyed }\end{array}$ \\
\hline $45 a / 53 a$ & Hayretī & $\begin{array}{l}\text { İy selāmet isteyen dāyim selāmet }{ }^{93} \text { ol yüri } \\
\text { Olma hāāî ‘ş̧ḳdan var ehl-i hāalet ol yüri }\end{array}$ & $\begin{array}{l}\text { Nice bir ümmīd-i vașl-1la bu derd ü bu belā } \\
\text { Nā-ümīd ol Ḥayretî 'ālemde rāhat ol yüri } \\
\text { 'Işḳa ḳul olalı olduñ mālik-i mülk-i belā } \\
\text { Begligüñ var iy göñül șāḥib-vilāyet ol yüri's }\end{array}$ & gazel/ 5 & ilahi & $\begin{array}{l}-.- \\
1-.-- \\
1-.-- \\
\text { /-.- }\end{array}$ & $\begin{array}{l}\text { Hayretī } \\
\text { Fermāyed }\end{array}$ \\
\hline $45 a / 53 a$ & Hayretī & $\begin{array}{l}\text { Pertev-i nūr-1 Ḩudādur 'işḳ-1 pāk } \\
\text { Ya'ni sırr-1 Mușțafādur 'işḳ-1 pāk }\end{array}$ & $\begin{array}{l}\text { Kulıuuz kururbānıyuz iy Ḥayretī } \\
\text { Milk-i dilde pādişāhdur '1şḳ-1 pāk }\end{array}$ & gazel/ 5 & ilahi & $\begin{array}{l}-.- \\
1-.-- \\
1-.-\end{array}$ & $\begin{array}{l}\text { Hayretī } \\
\text { Fermāyed }\end{array}$ \\
\hline $45 b / 53 b$ & Hayretī & $\begin{array}{l}\text { Reh-nümā-yı rāh-1 Haḳdur '1şḳ-1 pāk } \\
\text { 'Îlm-i tahḳ̂̄ḳa sebaḳdur '1şḳ-1 pāk }\end{array}$ & $\begin{array}{l}\text { Hayretī anuñla görür işidür } \\
\text { 'Āşsḳa gözdür ḳulaḳdur '1şḳ-1 pāk }\end{array}$ & gazel/ 5 & ilahi & $\begin{array}{l}--- \\
1-.-- \\
1-.-\end{array}$ & $\begin{array}{l}\text { Hayretī } \\
\text { Fermāyed }\end{array}$ \\
\hline $45 b / 53 b$ & Ḥayretī & $\begin{array}{l}\text { Çārsū-yı '1şḳa rüsvā olmayan hīç gelmesün } \\
\text { Bu tarīḳa bī-ser ü pā olmayan hīç gelmesün }\end{array}$ & $\begin{array}{l}\text { Zāglar yiri degüldür șūfiyā gülzār-1 'ışḳ } \\
\text { Ḥayretī teg murḡ-1 gūyā olmayan hīç gelmesün }\end{array}$ & gazel/ 5 & ilahi & $\begin{array}{l}-.-- \\
1-.-- \\
1-.-- \\
1-.-\end{array}$ & $\begin{array}{l}\text { Hayretīi } \\
\text { Fermāyed }\end{array}$ \\
\hline $46 a / 54 a$ & Ḥayretī & $\begin{array}{l}\text { Bezm-i gamda ney gibi nālān olan gelsün berü } \\
\text { Vāḳıf-1 esrār olup hayrān olan gelsün berü }\end{array}$ & $\begin{array}{l}\text { Hẹayretī gibi bugün meydānda şāhuñ '1şḳına } \\
\text { Cān }[u]^{95} \text { baş terk eyleyüp ḳurbān olan gelsün berü }\end{array}$ & gazel/ 7 & ilahi & $\begin{array}{l}-.- \\
1-.-- \\
1-.-- \\
1-.-\end{array}$ & $\begin{array}{l}\text { Hayretī } \\
\text { Fermāyed }\end{array}$ \\
\hline $46 b / 54 b$ & Hayretī & 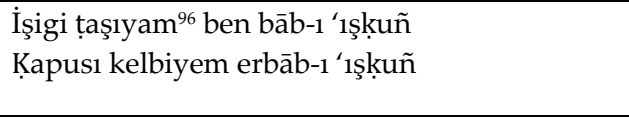 & $\begin{array}{l}\text { İşigüñ nice ḳosun Ḥayretī kim } \\
\text { Ḳapuñda oldı fethi bāb-1 '1şḳuñ }\end{array}$ & gazel/ 9 & ilahi & $\begin{array}{ll}.--- \\
\text { l.-- } \\
\text { l.-- } \\
\end{array}$ & $\begin{array}{l}\text { Hayretī } \\
\text { Fermāyed }\end{array}$ \\
\hline $47 a / 55 a$ & Hayretī & $\begin{array}{l}\text { Şūfîler virdi fenāya şehri hūy u hā ile } \\
\text { Mescidi meyhāneye dönderdiler gavgāā ile }\end{array}$ & 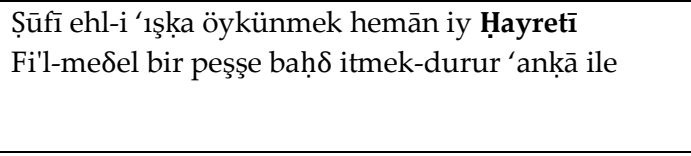 & gazel/ 5 & ilahi & $\begin{array}{l}--- \\
1-.-- \\
1-.-- \\
1-.-\end{array}$ & $\begin{array}{l}\text { Hayretī } \\
\text { Fermāyed }\end{array}$ \\
\hline $47 b / 55 b$ & Hayretī & $\begin{array}{l}\text { 'Āşık olmasun yanında ölmek āsān olmayan } \\
\text { Girmesün meydān-1 '1şḳa merd-i meydān }\end{array}$ & $\begin{array}{l}\text { Bezm-i ‘uşşāḳuñ șafāsın añlamaz iy Hayretī } \\
\text { ‘Ālem içre vālih ü ser-mest ü hayrān olmayan }\end{array}$ & gazel/ 5 & ilahi & $\begin{array}{l}-.- \\
1-.-- \\
\end{array}$ & $\begin{array}{l}\text { Heyretī } \\
\text { Fermāyed }\end{array}$ \\
\hline
\end{tabular}

93 selāmet: melāmet (Çavuşoğlu \& Tanyeri, 1981, s. 420). [Mana açısından Divan'daki uygundur.]

${ }^{94}$ Divan'da bu beyit üçüncü sıradadır (Çavuşoğlu \& Tanyeri, 1981, s. 420).

${ }^{95}$ Eksiklik Divan'dan tamamlandı (Çavusoğlu \& Tanyeri, 1981, s. 376).

96 țaşıyam: ḩākiyem (Çavuşoğlu \& Tanyeri, 1981, s. 256).

SEFAD, 2020; (44): 213-250 


\begin{tabular}{|c|c|c|c|c|c|c|c|}
\hline & & olmayan & & & & $\begin{array}{l}-.-- \\
1-.- \\
\end{array}$ & \\
\hline $48 a / 56 a$ & Ḥayretī & $\begin{array}{l}\text { Mahabbet milkinüñ sulțānıdur 'sşḳ } \\
\text { Mevedded 'āleminüñ cānıdur '1şḳ }\end{array}$ & $\begin{array}{l}\text { Ne bilsün Ḥayretī 'sşḳı her ādem } \\
\text { Ḥaḳuñ bir luțfidur iḥsānıdur 'sşḳ }\end{array}$ & gazel/ 5 & ilahi & $\begin{array}{l}--- \\
1 .--- \\
1 .--\end{array}$ & $\begin{array}{l}\text { Ḥayretī } \\
\text { Fermāyed }\end{array}$ \\
\hline $48 a / 56 a$ & Ḥayretī & $\begin{array}{l}\text { Yine cūş itdi deryā-yı mahabbet } \\
\text { Cihānı dutdı ġavġā-yı maḥabbet }\end{array}$ & $\begin{array}{l}\text { Ölicek Hayretī her üstüḩ̌ānuñ } \\
\text { Ola 'ālemde bir nāy-1 mahabbet }\end{array}$ & gazel/ 9 & ilahi & I.-- & $\begin{array}{l}\text { Hayretī } \\
\text { Fermāyed }\end{array}$ \\
\hline $48 b / 56 b$ & İbrāhīm & $\begin{array}{l}\text { Ol ‘sşk-1la miskīn olan } \\
\text { Ol kim işitdüñ ol benem } \\
\text { Göñül virüp gamgīn olan } \\
\text { Ol kim işitdüñ ol benem }\end{array}$ & $\begin{array}{l}\text { Men Mevlā-yı İbrāhimem } \\
\text { 'Ārif bilür kim men kimem } \\
\text { Dīzāra 'āşık (ben) miskinem } \\
\text { Ol kim işitdüñ ol menem }\end{array}$ & koşma/ 5 & ilahi & $\begin{array}{l}8^{\prime} \text { li } \\
\text { hec } \\
\text { e }\end{array}$ & $\begin{array}{l}\text { İbrāhīm Rāst } \\
\text { ‘Aleyhi'r- } \\
\text { Raḥmetü }\end{array}$ \\
\hline $49 a / 57 a$ & Kanber & $\begin{array}{l}\text { 'Aceb mevc-i nihāyetsüz ki gösterdi deñizden } \\
\text { rū } \\
\text { 'Aceb deryā-yı bī-pāyā ki andandur ḳamu } \\
\text { lülü }\end{array}$ & $\begin{array}{l}\text { 'Aceb sevdā ki başından giderdi Kanberüñ ‘aḳlın } \\
\text { Hayāl-i bü'l-'acebdür ki gözinde ḳomadı uyhuu }\end{array}$ & $\begin{array}{l}\text { gazel-i } \\
\text { mutavvel/ } \\
17\end{array}$ & ilahi & $\begin{array}{l}.--- \\
\text { 1.--- } \\
\text { /.--- } \\
\text { I.-- }\end{array}$ & $\begin{array}{l}\text { Ķanber Rāst } \\
\text { Kuddise } \\
\text { Sirruhu }\end{array}$ \\
\hline $50 \mathrm{~b} / 58 \mathrm{~b}$ & Kanber & $\begin{array}{l}\text { Gözlerüm ḳanda baḳsa cān görinür } \\
\text { Ṣanasın şāh-1 lā-mekān görinür }\end{array}$ & $\begin{array}{l}\text { Ger cinān cāna cāy ola Kanber } \\
\text { Ḳa'r-1 dūzah saña cinān görinür }\end{array}$ & $\begin{array}{l}\text { gazel-i } \\
\text { mutavvel/ } \\
16\end{array}$ & ilahi & $\begin{array}{l}.-- \\
\text { l.-.- } \\
\text { /..- }\end{array}$ & $\begin{array}{l}\text { Kanber } \\
\text { Ravvahạallāhu } \\
\text { Ruhạä'l-'Azīz }\end{array}$ \\
\hline $51 a / 59 a$ & Şirāzī & $\begin{array}{l}\text { Benem ol ț̣lsım-1 pinhān } \\
\text { Ki bugün 'ayāna geldüm } \\
\text { Ezelī nişānsiz-iken } \\
\text { Ebedī nişāna geldüm }\end{array}$ & $\begin{array}{l}\text { Ne kişi-durur Şirāzīi } \\
\text { Ki ‘ayān ide bu rāzı } \\
\text { Düzüben bu sözi sāzı } \\
\text { Benem uş beyāna geldüm }\end{array}$ & koşma/ 7 & ilahi & $\begin{array}{l}8^{\prime} \text { li } \\
\text { hec } \\
\text { e }\end{array}$ & $\begin{array}{l}\text { Şeyh Şirāzī Rāst } \\
\text { Kưddise } \\
\text { Sirruhu }\end{array}$ \\
\hline $51 b / 59 b$ & İbrāhīm & $\begin{array}{l}\text { Her kim añladı 'sşḳ hālinden } \\
\text { 'Ālemüñ geçdi ḳil ü ḳālinden }\end{array}$ & $\begin{array}{l}\text { Ebedī ‘ömre iren İ̉brāhīm } \\
\text { Dünyenüñ geçdi māh u }{ }^{97} \text { sālinden }\end{array}$ & kaside/ 18 & ilahi & $\begin{array}{l}.-- \\
\text { l.-.- } \\
\text { /..- } \\
\end{array}$ & $\begin{array}{l}\text { İbrāhīm Rāst } \\
\text { 'Aleyhi'r- } \\
\text { Raḥmetü }\end{array}$ \\
\hline $52 b / 60 b$ & İbrāhīm & $\begin{array}{l}\text { Her ki(m) sulțān-1 'sşḳa oldı nedīm } \\
\text { İki 'ālemde buldı 'izz ü na'îm }\end{array}$ & $\begin{array}{l}\text { Geçmişi ḳo gözetmegil geleni } \\
\text { Gözüñ aç hâāi hoş gör İbrāhīm }\end{array}$ & $\begin{array}{l}\text { terci-i } \\
\text { bend }^{98} / 7\end{array}$ & ilahi & $\begin{array}{l}. .- \\
\text { l.-.- } \\
\text { /..- } \\
\end{array}$ & $\begin{array}{l}\text { İbrāhīm Rāst } \\
\text { Ravvahallāhu } \\
\text { Ruhahu }\end{array}$ \\
\hline $52 b / 60 b$ & Hayretī & $\begin{array}{l}\text { Ehl-i ‘sşḳa küfr ü īmān bir olur } \\
\text { Vaṣl u hicrān derd ü dermān bir olur }\end{array}$ & $\begin{array}{l}\text { Ḥayretī gibi harābāt ehline } \\
\text { Ṭāḳ-1 eyvān genc-i vīrān bir olur }\end{array}$ & gazel/ 5 & ilahi & $\begin{array}{l}-.- \\
\text { l-.-- } \\
\text { l-.- } \\
\end{array}$ & $\begin{array}{l}\text { Hִayretī Rāst } \\
\text { Ḳaddesallāhu } \\
\text { Ruhahäül-'Azīz }\end{array}$ \\
\hline $53 a / 61 a$ & Hayretī & $\begin{array}{l}\text { Cān-ile iy gönül olalum mübtelā-yı ‘'sşk } \\
\text { ‘Uşşāḳa bal olur çü bilürsin belā-yı 'sşḳ }\end{array}$ & 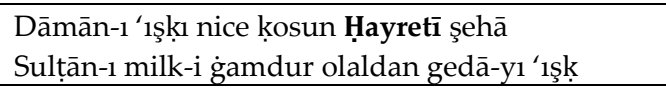 & gazel/ 5 & ilahi & $\begin{array}{ll}-. /- \\
-. / .-\end{array}$ & $\begin{array}{l}\text { Heayretī } \\
\text { Fermāyed }\end{array}$ \\
\hline
\end{tabular}

${ }^{97}$ māh u: makü (Bağçeci \& Deniz, 2019, s. 224). [Mana açısından Mecmua'daki uygundur.]

${ }^{98}$ Bu manzume Divan'daki bir terci-i bendin 6. bendidir. (Bağçeci \& Deniz, 2019, s. 231). 


\begin{tabular}{|c|c|c|c|c|c|c|c|}
\hline & & & & & &.$- /-.-$ & \\
\hline $53 b / 61 b$ & Ḥaḳīḳī & $\begin{array}{l}\text { Göñül bu derdine '1şḳuñ ‘aceb dermān nedür } \\
\text { bilmez } \\
\text { İrem dir vașlına yāruñ velī imkān nedür } \\
\text { bilmez }\end{array}$ & $\begin{array}{l}\text { Hekạị̄ị dürr-i meknūndur sözüñ bahrr-i hakāâyılkdan } \\
\text { Ne ola ḳymetin anuñ eger nādān nedür bilmez }\end{array}$ & kaside/ 23 & ilahi & $\begin{array}{l}.--- \\
\text { 1.-- } \\
\text { 1.--- } \\
\text { 1.--- }\end{array}$ & $\begin{array}{l}\text { Kașīde-i } \\
\text { Mevlānā Hạị̄ị̄i } \\
\text { Ḳuddise } \\
\text { Sirruhu }\end{array}$ \\
\hline $55 b / 63 b$ & Ḥaḳīḳ̄i & $\begin{array}{l}\text { Vaḳtidür ki bırag̉am bu ḩırḳa-1 sālūsı men } \\
\text { Uşadam çalup țaşa hem şişse-i nāmūsı men }\end{array}$ & $\begin{array}{l}\text { Sen Ḥaḳīḳīye hele zāhid țur ibrām eyleme } \\
\text { Tā ṣafā meydānı içre görmeyem bu būsı ben }\end{array}$ & gazel/ 9 & ilahi & $\begin{array}{l}-.-- \\
1-.-- \\
1-.-- \\
1-.-\end{array}$ & $\begin{array}{l}\text { Eyżan Lehü } \\
\text { Nevvarrallāhu } \\
\text { Kabrehu }\end{array}$ \\
\hline $56 a / 64 a$ & Cāmī & 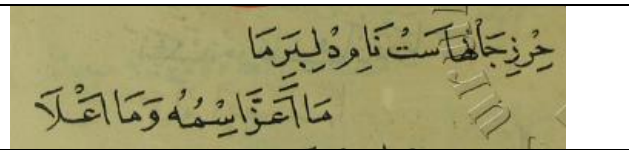 & 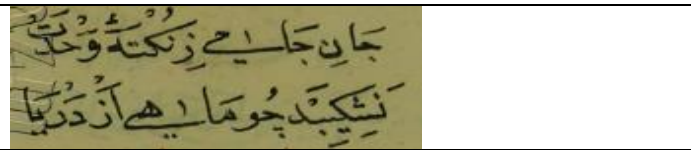 & gazel/ 7 & ilahi & $?$ & $\begin{array}{l}\text { Li-Mevlānā } \\
\text { Cāmī Rāst }\end{array}$ \\
\hline $56 \mathrm{~b} / 64 \mathrm{~b}$ & Ḥaḳị̄ị & $\begin{array}{l}\text { Gör ol mehtābı ki gerdūna sıġmaz } \\
\text { Gir ol seylāba ki Ceyhūna sığmaz }\end{array}$ & $\begin{array}{l}\text { Ḥaḳịḳi dürr-i deryā-yı ḥaḳiḳat } \\
\text { Ḳo naẓm-ı lü'lü'-i meknūna sig̀maz }\end{array}$ & gazel/ 9 & ilahi & $\begin{array}{l}--- \\
\text { /.-- } \\
\text { /.-- } \\
\end{array}$ & Velehü Eyżan \\
\hline $57 b / 65 b$ & Ḥaḳì̄ị̄ & $\begin{array}{l}\text { Bugün sevdā-yı 'ışkuñ başa șig̉maz } \\
\text { Gamuñ seylābı gözde yaşa sığmaz }\end{array}$ & 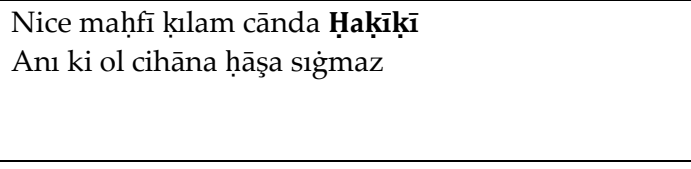 & gazel/ 5 & ilahi & $\begin{array}{l}.-- \\
\text { l.--- } \\
\text { l.-- }\end{array}$ & $\begin{array}{l}\text { Ḥaḳị̄ī } \\
\text { Fermāyed } \\
\text { Kuuddise } \\
\text { Surruhu } \\
\end{array}$ \\
\hline $57 b / 65 b$ & $\begin{array}{l}\text { Cemāl-i } \\
\text { Haalvetī }\end{array}$ & $\begin{array}{l}\text { 'Avn-1 Ḥaḳ irdi baña kendümi vīrān eyledüm } \\
\text { Teslīm-i cān eyleyüp derdüme dermān } \\
\text { eyledüm }\end{array}$ & $\begin{array}{l}\text { Bu Cemāl-i Halvetī şol dōst visāli yolına } \\
\text { Ḳıldı cānını fidā sırrını ḩandān eyledüm }\end{array}$ & gazel/ 5 & ilahi & $\begin{array}{l}-.-- \\
\text { l-.-- } \\
\text { l-.- }\end{array}$ & $\begin{array}{l}\text { Mevlānā } \\
\text { Cemāl-i Hূalvetī } \\
\text { Fermāyed }\end{array}$ \\
\hline $58 a / 66 a$ & Gülşen̄̄ & $\begin{array}{l}\text { Nedür 'sşḳuñ țarīḳın bilmek olmaz } \\
\text { Ki 'aḳl-ile o yola girmek olmaz }\end{array}$ & $\begin{array}{l}\text { 'Aceb bu Rūşenīden Gülşenī }{ }^{101} \\
\text { Güneş nisbet bahuban görmek olmaz }\end{array}$ & gazel/ 5 & ilahi & /.--- & $\begin{array}{l}\text { Mevlānā } \\
\text { Gülşenī İbn-i } \\
\text { Mevlānā Rūşenī } \\
\text { Rāst } \\
\text { Ravvahallāhu } \\
\text { Ruhahu }\end{array}$ \\
\hline $58 a / 66 a$ & Ușūlī & Elā iy kendüyi ‘āşıḳ șananlar & Ușūlī vāz gel sen bu beyāndan & mesnevi/ & ilahi & 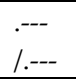 & Mesnevī-i Ușūlī \\
\hline
\end{tabular}

99 eyleme: olmag̀il (Boz, 2017, s. 684).

100 tā șafā meydānı içre görmeyem bu pūsı ben: urmışam bāzār-1 rüsvāyı da çün bu kūsı men (Boz, 2017, s. 684). [Mana açısından Mecmua'daki uygundur.]

${ }^{101}$ Rūşenīden Gülşenī: Gülşen̄̄ 'sşḳuñ dirisin (Akay, 1996, s. 65). [Vezin açısından Divan'daki uygundur.]

SEFAD, 2020; (44): 213-250 


\begin{tabular}{|c|c|c|c|c|c|c|c|}
\hline & & Serāb-1 huşki șu șanup ḳananlar & $\begin{array}{l}\text { 'Ayān eyle sözi külle lisāndan }{ }^{102} \\
\text { Bu bahrüñ̃ ḥaddi vü pāyānı yoḳdur } \\
\text { Ki șigmaz [gözine] }{ }^{103} \text { imkānı yoụdur } \\
\end{array}$ & 31 & & /.-- & $\begin{array}{l}\text { Rāst } \\
\text { Nevvarrallāhu } \\
\text { Merḳadehu }\end{array}$ \\
\hline $59 b / 67 b$ & Şemseddīn & $\begin{array}{l}\text { İy 'āşıkān iy 'âşıḳān ben cān u cānān } \\
\text { bulmışam } \\
\begin{array}{l}\text { İy șādıḳāt } \\
\text { bulmışam }\end{array}\end{array}$ & $\begin{array}{l}\text { Zuerrem ḳaçan 'āşık ola şemse irer iy Şemsedīn } \\
\text { Żerrem ḳatında żerre şems 'ālemde tābān bulmışam }\end{array}$ & gazel/ 6 & ilahi & $\begin{array}{l}-\cdot .- \\
1-.-- \\
1-. .- \\
1--.-\end{array}$ & $\begin{array}{l}\text { Mevlānā } \\
\text { Şemseddīn Rāst } \\
\text { Ravvahạallāhu } \\
\text { Ruhahu }\end{array}$ \\
\hline $60 a / 68 a$ & Cāmì & 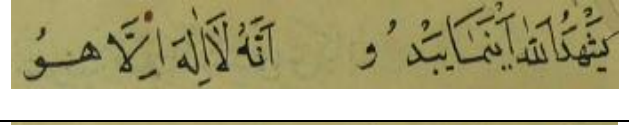 & & gazel/ 6 & ilahi & $?$ & $\begin{array}{l}\text { Mevlānā Cāmī } \\
\text { Rāst } \\
\text { Raḥimehullāhu }\end{array}$ \\
\hline $60 a / 68 a$ & Cāmìn & Glag & & gazel/ 6 & ilahi & $\begin{array}{l}-.-- \\
1-.-- \\
1-.-- \\
1-.- \\
\end{array}$ & $\begin{array}{l}\text { Mevlānā Cāmī̄ } \\
\text { Rāst 'Aleyhi'r- } \\
\text { Raḥmetü ve'l- } \\
\text { Gufrān }\end{array}$ \\
\hline $60 b / 68 b$ & Ḥaḳị̣̂ì & $\begin{array}{l}\text { Derd-ile göñül ḳılur cūş'104 } \\
\text { Derdini çü '1şḳuñ eyledi nūş }\end{array}$ & $\begin{array}{l}\text { Ġarḳ olsa Hekâị̄ị ‘sşḳa țañ mı } \\
\text { Deryāya olup-durur yolı țuş }\end{array}$ & gazel/ 13 & ilahi & $\begin{array}{l}--\cdot / .- \\
.---\end{array}$ & $\begin{array}{l}\text { Ḩaḳik̄ì } \\
\text { Nevvarrallāhu } \\
\text { Kabrehu }\end{array}$ \\
\hline $61 a / 69 a$ & Ḥaḳịḳ̄ & $\begin{array}{l}\text { Sevdā-yı '1şḳıñuñ yār dīvānesi menem men } \\
\text { Şem'-i cemālinüñ dōst pervānesi menem men }\end{array}$ & 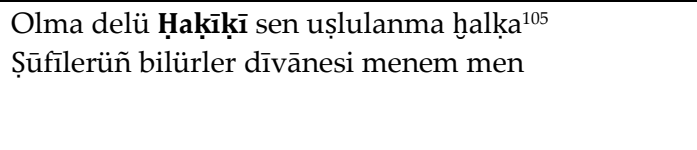 & gazel/ 7 & ilahi & $\begin{array}{l}--. /- \\
.--/- \\
-. /--- \\
-\end{array}$ & $\begin{array}{l}\text { Eyżan Lehü } \\
\text { Kuddise } \\
\text { Sirruhu }\end{array}$ \\
\hline $61 b / 69 b$ & Ḥaḳị̄ị & $\begin{array}{l}\text { ‘Işḳ āteşi-durur göñüle cān didükleri } \\
\text { Derdüñ-durur hemāñ bize dermān didükleri }\end{array}$ & $\begin{array}{l}\text { Eksükligüñ Haḳị̄ịi bilüp bağla ḳullı̀ga } \\
\text { Bilüñ ki bu-durur ḳula 'irfān didükleri }\end{array}$ & gazel/ 9 & ilahi & $\begin{array}{l}--. /- \\
--. / .- \\
-. /-.-\end{array}$ & $\begin{array}{l}\text { Velehü Eyżan } \\
\text { 'Aleyhi'r- } \\
\text { Raḥmetü ve'l- } \\
\text { Gufrān }\end{array}$ \\
\hline $62 b / 70 b$ & Ḥaḳị̄ị̄ & 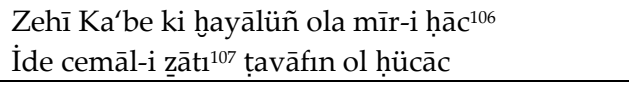 & 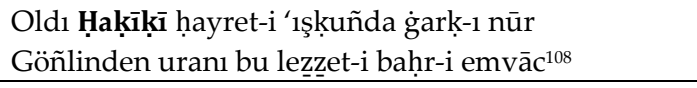 & gazel/ 9 & ilahi & $\begin{array}{l}--\cdot /- \\
--. / \cdot-\end{array}$ & $\begin{array}{l}\text { Velehü Eyżan } \\
\text { Ravvahallāhu }\end{array}$ \\
\hline
\end{tabular}

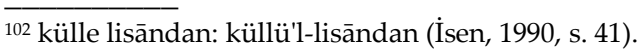

${ }_{103}$ Bu kelime mecmuadan okunamadı̆̆ için Divan'dan alınmıștır (İsen, 1990, s. 41).

${ }^{104}$ derd-ile göñül ḳılur: derd-ile kılur yine göñül (Boz, 2017, s. 374). [Vezin açısından Divan'daki uygundur.]

105 halka: ki halk (Boz, 2017, s. 686). [Mana açısından Mecmua'daki uygundur.]

106 zehī Ka'be ki hayāäüñ ola: zī-Ka'be ki hayālüñ ola aña (Boz, 2017, s. 172). [Vezin açısından Divan'daki uygundur.]

107 zātı: zāt-1la (Boz, 2017, s. 172). [Vezin açısından Divan'daki uygundur.]

108 uranı bu ležzet-i bahrr-i emvāc: uralı bu ledünnī baḥr emvāc (Boz, 2017, s. 172). [Mecmua ve Divan'daki misraların her ikisi de vezin açısından kusurludur.] 


\begin{tabular}{|c|c|c|c|c|c|c|c|}
\hline & & & & & &.$- /-.-$ & Ruhahü'l-'Azīz \\
\hline $63 a / 71 a$ & Gülşen̄̄ & $\begin{array}{l}\text { ‘Ișḳ ehline cennet gibi yüzüñ gül-i gülzār-imiş } \\
\text { ‘Āşıł olanuñ cenneti ma'şūḳdan dīdār-imiş }\end{array}$ & $\begin{array}{l}\text { Nūr-1 tecellī109 sırrını vechüñ gören bilür nedür } \\
\text { K'ol Rūşenīden Gülşenī gördügi nūr-1 yār-imiş }{ }^{110}\end{array}$ & gazel/ 5 & ilahi & $\begin{array}{l}-.- \\
\text { /--.- } \\
\text { /--.- } \\
\text { /--.- }\end{array}$ & $\begin{array}{l}\text { Mevlānā } \\
\text { Gülşenī Rāst } \\
\text { Ravvaḥallāhu } \\
\text { Ruhahu }\end{array}$ \\
\hline $63 b / 71 b$ & Ḥasan & $\begin{array}{l}\text { Ben beni bende bulmışam } \\
\text { Cān-1 cihān ben olmışam } \\
\text { Cümle cihāna țolmışam } \\
\text { Cān-1 cihān ben olmışam }\end{array}$ & $\begin{array}{l}\text { Gerden-i cānda iy Ḥasan } \\
\text { ‘şş̣-1 ilāhīdü[r] resen } \\
\text { Şevk-ile bunı di ki sen } \\
\text { Cān u cihān ben olmışam }\end{array}$ & koşma/ 5 & ilahi & $\begin{array}{l}\text { 8'li } \\
\text { hec } \\
\text { e }\end{array}$ & $\begin{array}{l}\text { Mevlānā Ḥasan } \\
\text { Rāst } \\
\text { Ravvahallāhu } \\
\text { Ruhahu }\end{array}$ \\
\hline $64 a / 72 a$ & Cemālī & $\begin{array}{l}\text { Cān u baş terk itmedin cānānı ārzū eyleme } \\
\text { Zünnārı bilden kesmedin īmānı ārzū eyleme }\end{array}$ & $\begin{array}{l}\text { Dök Cemālī göz yaşın ‘ālemde rüsvāy olıgör } \\
\text { Ad u șandan geçmeseñ Raḥmānı ārzū eyleme }\end{array}$ & gazel/ 5 & ilahi & $\begin{array}{l}-.- \\
\text { /-.-- } \\
\text { /-.-- } \\
\text { /-.- }\end{array}$ & $\begin{array}{l}\text { Cemālī } \\
\text { Fermāyed } \\
\text { Nevvarallāhu } \\
\text { Kabrehu }\end{array}$ \\
\hline $64 b / 72 b$ & $\begin{array}{l}\text { Cemāl-i } \\
\text { Hulvetī }\end{array}$ & $\begin{array}{l}\text { Iraḳdan isteyen bulmaz hakīikat şāh-1 sulțānı } \\
\text { Yaḳındur saña senden ol oḳımaduñ mı } \\
\text { Kur'ānı }\end{array}$ & $\begin{array}{l}\text { Cemāl-i Halvetī sen de götürdüñ bilmedüñ sırr ne } \\
\text { Ḳatı nefsüñe ẓulm itdüñ țutuban buyruğ-1 hāāı }\end{array}$ & gazel/ 7 & ilahi & $\begin{array}{l}.-- \\
\text { /.--- } \\
\text { /.--- }\end{array}$ & $\begin{array}{l}\text { Cemāl-i Halvetī } \\
\text { Rāst } \\
\text { Ravvahallāhu } \\
\text { Ruhahu }\end{array}$ \\
\hline $65 a / 73 a$ & $\begin{array}{l}\text { Cemāl-i } \\
\text { Halvetī }\end{array}$ & $\begin{array}{l}\text { Haḳịkat şem'ine perde ne hikmetden vücūd } \\
\text { oldı } \\
\text { Anuñ ẓıllı-iken aña bu șūretden şühūd oldı }\end{array}$ & $\begin{array}{l}\text { Cemāl-i Halvetī dir kim Ḥaḳuñ ef'ālidür görnen } \\
\text { Egerçi ‘âlem içinde nice dürlü vücūd oldı }\end{array}$ & gazel/ 7 & ilahi & $\begin{array}{l}\text { I.--- } \\
\text { /.--- } \\
\text { /.--- }\end{array}$ & $\begin{array}{l}\text { Cemāl-i Halvetī } \\
\text { Fermāyed } \\
\text { Nevvarallāhu } \\
\text { Kabrehu }\end{array}$ \\
\hline $65 b / 73 b$ & Gülşenī & 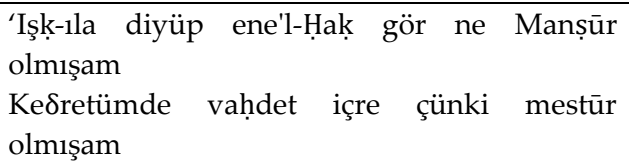 & $\begin{array}{l}\text { Zikr iderken '1şḳuñ-1la fikrüñ idüp uş meni } \\
\text { Zāākir-iken Gülşenī-veş 'ayn-1 mežkūr olmışam }\end{array}$ & gazel/ 5 & ilahi & $\begin{array}{l}-.-- \\
\text { /-.-- } \\
\text { /-.-- } \\
\text { /-.- }\end{array}$ & $\begin{array}{l}\text { Gülşenī } \\
\text { Fermāyed } \\
\text { Raḥmetullāhu } \\
\text { Te'ālā }\end{array}$ \\
\hline $66 a / 74 a$ & Fütūḥī & $\begin{array}{l}\text { Ol āsitāne yüz sürüp } \\
\text { Derbān olayın varayın } \\
\text { Bir nā-tüvān bende-iken } \\
\text { Sulțān olayın varayın }\end{array}$ & $\begin{array}{l}\text { İy Fütūḥi bilgil hemān } \\
\text { Cürm ü günāh olmaz nihān } \\
\text { Emr-i Hakạa [ben] her zamān } \\
\text { Fermān olayın varayın }\end{array}$ & koşma/ 5 & ilahi & $\begin{array}{l}\text { 8'li } \\
\text { hec } \\
\text { e }\end{array}$ & $\begin{array}{l}\text { Fütūḥ̄ì } \\
\text { Fermāyed } \\
\text { Nevvarallāhu } \\
\text { Kabrehu }\end{array}$ \\
\hline $66 \mathrm{~b} / 74 \mathrm{~b}$ & Şemseddīn & $\begin{array}{l}\text { Her zamān göñlüm evin vīrān ider gavgiā-yı } \\
\text { ‘ş̧̧ }\end{array}$ & $\begin{array}{l}\text { Ṭīb-1 enfāsuñ cihānı țutdı Şemseddīn temām } \\
\text { Bir araya gerçi micmer gibi dikdi pāy-1 'sşk }\end{array}$ & gazel/ 7 & ilahi & $\begin{array}{l}-.-- \\
\text { /-.-- } \\
\text { /-.-- }\end{array}$ & $\begin{array}{l}\text { Mevlānā } \\
\text { Şemseddīn Rāst }\end{array}$ \\
\hline
\end{tabular}

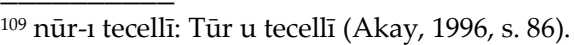

110 nūr-1 yār-imiș: nūr u nār-ımıș (Akay, 1996, s. 86). [Mana açısından Mecmua'daki uygundur.]

${ }^{111}$ Misra vezin açısından kusurludur.

SEFAD, 2020; (44): 213-250 


\begin{tabular}{|c|c|c|c|c|c|c|c|}
\hline & & Dār-1 zülffinde beni berdār ider sevdā-yı 'sşḳ & & & & /-.- & $\begin{array}{l}\text { Ravvaḥallāhu } \\
\text { Ruhahü'l-'Azīz }\end{array}$ \\
\hline $67 a / 75 a$ & Ġarībī & $\begin{array}{l}\text { Naḳdüñi vir rāh-ı 'sşḳa menzil-i ḳurbiyyet al } \\
\text { Cenneti dīdāra șat cān-ile maḳbūliyyet al }\end{array}$ & $\begin{array}{l}\text { Āfitābuñ tābına yanma Ġarībī zerre-veş } \\
\text { 'Āḳil-iseñ kāyinātuñ cānibinden 'ibret al }\end{array}$ & gazel/ 5 & ilahi & $\begin{array}{l}-.-- \\
\text { /-.-- } \\
\text { /-.-- } \\
\text { /-.- }\end{array}$ & $\begin{array}{l}\text { Garāibī Rāst } \\
\text { Raḥmetullāh }\end{array}$ \\
\hline $\begin{array}{l}\text { 67a/Dk75 } \\
\text { a }\end{array}$ & - & 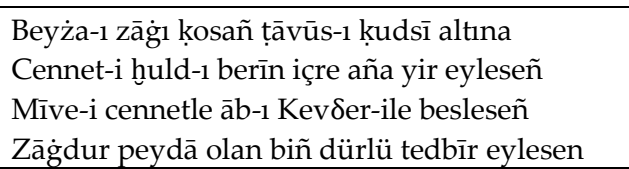 & & $?$ & $?$ & $\begin{array}{l}.-- \\
1-.-- \\
1-.-- \\
1-.-\end{array}$ & $\begin{array}{l}\text { Güft Ḥażret-i } \\
\text { 'Ali }\end{array}$ \\
\hline $\begin{array}{l}67 \mathrm{a} / \mathrm{Dk} 75 \\
\mathrm{a}\end{array}$ & - & Hoş buyurmışdur bunı ehl-i idrāk & & müfred & $?$ & $?$ & Ve Lehü \\
\hline $\begin{array}{l}\text { 67a/Dk75 } \\
\text { a }\end{array}$ & - & $\begin{array}{l}\text { Ferīd-i rūzigār olsa lisān-1 @ilm-ile bir Türk } \\
\text { Mizācın[d]a anuñ așlā eşeklik olmaya eksik }\end{array}$ & & müfred & $?$ & $\begin{array}{l}.-- \\
\text { /.--- } \\
\text { /.-- } \\
\text { /.-- }\end{array}$ & Ve Lehü \\
\hline $\begin{array}{l}\text { 67a/Dk75 } \\
\text { a }\end{array}$ & - & $\begin{array}{l}\text { Türke bir vech-ile ādem dimezem billāhī } \\
\text { İtikāād itmem [aña] irse semāya külahı }\end{array}$ & & müfred & ? & $\begin{array}{l}. .-- \\
\text { /..-- } \\
\text { /..-- } \\
\text { /..- }\end{array}$ & Ve Lehü \\
\hline $\begin{array}{l}67 \mathrm{~b} / \\
75 \mathrm{~b}\end{array}$ & $\begin{array}{l}\text { Cemāl-i } \\
\text { Halvetī }\end{array}$ & $\begin{array}{l}\text { ‘Işḳ deryāsında garḳ olsam diyen cāndan geçe } \\
\text { Maḥv idüp kendü vücūddan zenb-i 'isyāndan } \\
\text { geçe }\end{array}$ & $\begin{array}{l}\text { Gel Cemāl-i Halvetī bülbül gibi terk eyle cān } \\
\text { Lezzzeti bulup bu nefsüñ gülsitānından geçe }\end{array}$ & gazel/ 7 & ilahi & $\begin{array}{l}-.-- \\
\text { /-.-- } \\
\text { /-.-- } \\
\text { /-.- }\end{array}$ & $\begin{array}{l}\text { Cemāl-i Hualvetī } \\
\text { Fermāyed } \\
\text { Nevvarallāhu } \\
\text { Kabrehu }\end{array}$ \\
\hline $68 a / 76 a$ & $\begin{array}{l}\text { Cemāl-i } \\
\text { Halvetī }\end{array}$ & $\begin{array}{l}\text { Ṭālibüm diyen niçün feryād u efğān eylemez } \\
\text { Ya niçün șımaz bu ten gencini nālān eylemez }\end{array}$ & $\begin{array}{l}\text { Bu Cemāl-i Halvetī bir lāubālī kimsedür } \\
\text { Dōst yolında cān virenden sırrı pinhān eylemez }\end{array}$ & gazel/ 7 & ilahi & $\begin{array}{l}-.-- \\
\text { /-.-- } \\
\text { /-.-- } \\
\text { /-.- }\end{array}$ & $\begin{array}{l}\text { Cemāl-i Hualvetī } \\
\text { Fermāyed } \\
\text { Nevvarallāhu } \\
\text { Kabrehu }\end{array}$ \\
\hline $68 b / 76 b$ & Halvetī & $\begin{array}{l}\text { Bu göñül milkini uş yagimaladı sulțānı hū } \\
\text { Aldı cān iḳlimini ḳurdı hemān eyvān hū }\end{array}$ & $\begin{array}{l}\text { Bu Halvetī sözinüñ sırrını ol hūdan bilüññ } \\
\text { Söyleden dilini hūdur sırr-1 hūdur cān-ı hū }\end{array}$ & gazel/ 9 & ilahi & $\begin{array}{l}-.-- \\
\text { /-.-- } \\
\text { /-.-- } \\
\text { /-.- }\end{array}$ & $\begin{array}{l}\text { Halvetī } \\
\text { Fermāyed } \\
\text { Raḥmetullāhu } \\
\text { Te'ālā }\end{array}$ \\
\hline
\end{tabular}




\begin{tabular}{|c|c|c|c|c|c|c|c|}
\hline $69 b / 77 b$ & Yūnus & $\begin{array}{l}\text { Cānlar fidā yoluña } \\
\text { Bu cān kayayusı degül } \\
\text { Sen cānı gerek baña } \\
\text { Cihān ḳayusı degül }\end{array}$ & $\begin{array}{l}\text { Dirler 'āşı Yūnususa } \\
\text { Añlar bile gidelüm } \\
\text { Baña dōstum ḳayusı } \\
\text { Kārvān ḳayusı degül }{ }^{113}\end{array}$ & koşma/ 5 & ilahi & $\begin{array}{l}\text { 7'li } \\
\text { hec } \\
\text { e }\end{array}$ & $\begin{array}{l}\text { Yūnus Emre } \\
\text { Fermāyed } \\
\text { Ravvaḥallāhu } \\
\text { Ruhahä'l-'Azīz }\end{array}$ \\
\hline $69 b / 77 b$ & Gülşenī & $\begin{array}{l}\text { Girüp meydān-ı '1şk içre başın tọp eyleyen } \\
\text { gelsün } \\
\text { Ayaḳ yirine başını o meydāna ḳoyan gelsün }\end{array}$ & $\begin{array}{l}\text { Cihānı terk iden giyer başına Rūşenī tācın } \\
\text { O tācı Gülşenī gibi bu terk-ile geyen gelsün }\end{array}$ & gazel/ 7 & ilahi & $\begin{array}{l}.-- \\
\text { /.-- } \\
\text { /.--- }\end{array}$ & $\begin{array}{l}\text { Gülşenī Rāst } \\
\text { Ķuddise } \\
\text { Sirruhu }\end{array}$ \\
\hline $70 a / 78 a$ & Cemālī & $\begin{array}{l}\text { Çün beyān oldı rumūz-1 'alleme'l-esmāa } \bar{a}^{114} \text { bize } \\
\text { Rūşen oldı nükte-i sırr-1 Şeb-i İsrāā115 bize }\end{array}$ & $\begin{array}{l}\text { İy Cemālī gāâil olma ol hümāyūn-pīşeyüz } \\
\text { Kim ḳılur her dem tecellī Ḳaăfdan 'Anḳā bize'116 }\end{array}$ & gazel/ 9 & ilahi & $\begin{array}{l}-.- \\
\text { /-.-- } \\
\text { /-.-- } \\
\text { /-.- }\end{array}$ & $\begin{array}{l}\text { Cemālī } \\
\text { Fermāyed } \\
\text { Nevvarallāhu } \\
\text { Kabrehu }\end{array}$ \\
\hline $71 a / 79 a$ & $\begin{array}{l}\text { Cemāl-i } \\
\text { Halvetī }\end{array}$ & $\begin{array}{l}\text { Tecellī eyleseñ 'ayn-ı devādur } \\
\text { İçürmek anı 'uşşāḳa revādur }\end{array}$ & $\begin{array}{l}\text { Cemāl-i Halvetī hīç nesne bilmez } \\
\text { Senüñ nūruñdan özge ol şifādur }\end{array}$ & gazel/ 5 & ilahi & $\begin{array}{l}.-- \\
\text { /.-- } \\
\text { /.-- }\end{array}$ & $\begin{array}{l}\text { Cemāl-i Hualvetī } \\
\text { Fermāyed } \\
\text { Raḥmetullāhi } \\
\text { Te'ālā }\end{array}$ \\
\hline $71 a / 79 a$ & Cemālī & $\begin{array}{l}\text { Cān dirìg iden irişemez vașl-ı nigāra } \\
\text { Ḳılmaz naẓarı bülbül olan gökdeki gāra }\end{array}$ & $\begin{array}{l}\text { Nefsüñi Cemālī kıllagör pāk lațîf sen } \\
\text { Tā fażlı irişe giresin Halvetī dāra }\end{array}$ & gazel/ 5 & ilahi & $\begin{array}{l}-. / .- \\
-. / .-- \\
. / .--\end{array}$ & $\begin{array}{l}\text { Cemālī } \\
\text { Fermāyed } \\
\text { Nevvarallāhu } \\
\text { Kabrehu }\end{array}$ \\
\hline $71 b / 79 b$ & {$\left[\right.$ [Ǵazālī] ${ }^{117}$} & & & gazel/ 9 & ilahi & $?$ & Şi'r \\
\hline $72 a / 80 a$ & Yūnus & $\begin{array}{l}\text { İşidüñ hey yārenler } \\
\text { Ḳiymetli nesnedür '1şḳ } \\
\text { Degmelere bitimez }\end{array}$ & $\begin{array}{l}\text { Miskīn Yūnus neylesün } \\
\text { Derdin kime söylesün } \\
\text { 'Işkuñ odına yansun }\end{array}$ & koşma/ 6 & ilahi & $\begin{array}{l}\text { 7'li } \\
\text { hec } \\
\text { e }\end{array}$ & $\begin{array}{l}\text { Yūnus } \\
\text { Fermāyed }\end{array}$ \\
\hline
\end{tabular}

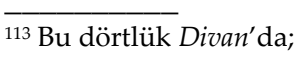

Yūnusu ögütlerler kalk kervān göçdü derler

Ben menzile erişdim kervān kayısı değil seklindedir (Tatcı, 2008, s. 180).

${ }^{114}$ Bu terkip şu ayetten iktibastır: "Ve alleme âdemel esmâe kullehâ: ve Allah, Adem'e bütün isimleri öğretti..." (Kur'an-1 Kerim 2: 31).

115 şeb-i isrā: şeb-i esrā (Ayan, 1990, s. 320). [ Mana açısından Mecmua'daki uygundur.]

${ }_{116}$ Bu gazel Cemālì Divani'nda bulunamamıştır (Karaman, 2002). Ancak Nesìmī Divanı'nda aynı gazele rastlanmıştır (Ayan, 1990, s. 320). Bu duruma makalenin inceleme kısmında ayrıca değinilmiştir.

${ }_{117}$ Bu gazel Arapça bir eser içinde Ġazāli'ye ait gösterilmektedir (Abdulmahmûd, 2019, s. 421).

SEFAD, 2020; (44): 213-250 


\begin{tabular}{|c|c|c|c|c|c|c|c|}
\hline & & Ḥurmetli nesnedür '1şḳ & Key țatlu nesnedür ışk & & & & \\
\hline $72 b / 80 b$ & Şeyhīì & $\begin{array}{l}\text { Hुoş menzil-idi dehr degülmisse fenāsı } \\
\text { Hुoş mahrem-idi ‘ömr olurmussa bekāsı }\end{array}$ & $\begin{array}{l}\text { Şeyb̄ī bilür anı bu ḳamu ḳaḍ̂̄ vü dānī } \\
\text { K'oldı dil ü cānuñ biri 'āṣī biri kāāī } \\
\text { Tehzīb-i șıāât itmege tedbīr-i ‘amel ḳıl } \\
\text { Taḳdīr-iledür gerçi ki olmış u olası }\end{array}$ & kaside/ 26 & ilahi & $\begin{array}{l}-. / .- \\
-. / .-- \\
. /--\end{array}$ & $\begin{array}{l}\text { Ķașīde-i } \\
\text { Şeyhü̈ş-Şu'arā } \\
\text { Şeyhīī } \\
\text { Raḥmetullāhi } \\
\text { ‘Aleyh }\end{array}$ \\
\hline $\begin{array}{l}74 b / \\
82 b^{118}\end{array}$ & Mușțafā & $\begin{array}{l}\text { Çünkim alur işbu tāc u taḩtı devr-i rūzigār } \\
\text { Terk idüp bu raht u baḩtı bir nemed ḳıl iḩtiyār } \\
\text {... } \\
\text { Cehd ḳıl senden ḳala dünyāda bir ḩoş yādigār } \\
\text { Ḥāṣılı bu devr elinden oldı ‘aḳlum tarumar }\end{array}$ & $\begin{array}{l}\text { Çün kim eşcāruñ külāhın ḳapdı peyk-i bī-direng } \\
\text { Ḳırdı ezhāruñ çerisin itmedin bir laḥẓa ceng } \\
\text {.. } \\
\text { Olmışam ḥayrān u vālih yimeden afyon u beng } \\
\text { Bil saña kim așṣı itmez Mușțafā bu nām u neng }\end{array}$ & muaşşer/ 6 & ilahi & $\begin{array}{l}-.- \\
\text { /-.-- } \\
\text { /..-- } \\
\text { /-.- }\end{array}$ & $\begin{array}{l}\text { Mevlānā Sulțān } \\
\text { Muștafāā Rāst }\end{array}$ \\
\hline $\begin{array}{l}77 a / \\
85 a^{119}\end{array}$ & $\begin{array}{l}\text { Cemāl-i } \\
\text { Halvetī }\end{array}$ & $\begin{array}{l}\text { İ gaăfil niçeye degin öziñi ḳılasın maḥūb } \\
\text { Gel imdi yık hicābuñ katında ol Haḳuñ } \\
\text { maḥbūb }\end{array}$ & $\begin{array}{l}\text { Cemāl-i Halvetī dervīş țutuñ söyledügin ma'zūūr } \\
\text { Müyesser tā size evvel ezelden nūş olan meşrūb }\end{array}$ & gazel/ 7 & ilahi & $\begin{array}{l}\text { I.-- } \\
\text { /.--- } \\
\text { /.--- } \\
\text { /.-- }\end{array}$ & $\begin{array}{l}\text { Mevlānā } \\
\text { Cemāl-i Halvet̄̄ } \\
\text { Rāst'Aleyhi'r- } \\
\text { raḥmetü }\end{array}$ \\
\hline $77 b / 85 b$ & Cāmì & 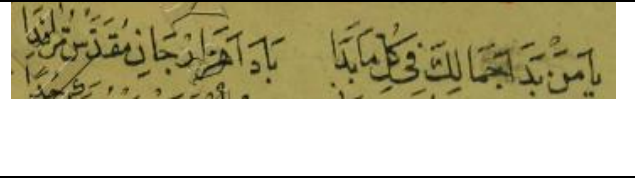 & كin & & ilahi & $\begin{array}{l}-. . /- \\
--. / .- \\
-. /-.-\end{array}$ & $\begin{array}{l}\text { Mevlānā Cāmī } \\
\text { Rāst } \\
\text { Raḥmetullāhi } \\
\text { Te'ālā }\end{array}$ \\
\hline $\begin{array}{l}78 a^{120} / \\
86 a\end{array}$ & $\begin{array}{l}{[\text { Ferag }} \\
\text { Kaydi] }\end{array}$ & $\begin{array}{l}\text { Temmet bi-'avnillāhi } \\
\text { Ḩayra yazsun şerrini anuñ Kirāmen kātibīn } \\
\text { Her kim añarsa du'ādan işbu haț̣̂ñ kâtibin }\end{array}$ & & & & $\begin{array}{l}-.-- \\
1-.-- \\
1-.-- \\
1-.-\end{array}$ & \\
\hline
\end{tabular}

118 84b'de der-kenar hâlinde mecmuanın hattından farklı bir hatla bazı tarifler ve fevaid addedebilecek notlar yer almaktadır.

119 85a'da der-kenar hâlinde mecmuanın hattından farklı bir hatla bir muhtasar zeyli vardır.

78b'de mecmuadan farklı bir hatla Derviş mahlasıyla;

Eger zāhid sorar-iseñ bize kadrüñ cevābını

Haḳịkat ḳadre irendür aça gönül kitābını

matlalı bir şiir yer almaktadır. Ancak Gölpınarlı(1932) bu şiiri Kaygusuz Vizeli Alaaddin adlı kitabında yayınlamıştır (s. 50). 


\section{KAYNAKÇA}

Abdulmahmûd b. N. D. (2019). Ravzu'l me'ânî ve mecâlisü'l-'üns ve't-tehânî. Beyrut, Lübnan: Books-Publisher.

Akay, M. (1996). İbrâhim Gülşenî'nin divanı (Doktora tezi). Erişim adresi: https://tez.yok.gov.tr/UlusalTezMerkezi/giris.jsp.

Ayan, H. (1990). Nesîmî divanı. Ankara: Akçă̆ Yay.

Aydemir, Y. (2007). Metin neşrinde mecmûaların rolü ve karşılaşılan problemler. Turkish Studies, 2/3, 122-137. http://dx.doi.org/10.7827/TurkishStudies.118.

Aydemir, Y. (2013). Mecmualara sorulmas1 gereken sorular. Turkish Studies, 8/1, 51-64. http://dx.doi.org/10.7827/TurkishStudies.4633.

Azamat, N. (2000). İbrâhim Gülşenî. Türkiye diyanet vakfi İslam ansiklopedisi (C. 21, s. 301-304). İstanbul: Divantaş.

Bağçeci, M. \& Deniz, R. (2019). Şeyh İbrahim Tennûrî ve Gülşen-i Niyâz. Kayseri: Kayseri Büyükşehir Belediyesi Kültür Yay.

Baltacı, C. (2011). Tasavouf lügatı. İstanbul: Gelenek Yay.

Bilgin, A. A. (2007). Nesîmî. Türkiye diyanet vakfı İslam ansiklopedisi (C. 33, s. 5-6). İstanbul: TDV Yayın Matbaacılık ve Ticaret İşletmesi.

Boz, E. (2013). Yûsuf Hakîkî. Türkiye diyanet vakfı İslam ansiklopedisi (C. 44, s. 137-155). İstanbul: TDV Yayın Matbaacılık ve Ticaret İşletmesi.

Boz, E. (2017). Hakîkî divanı. Erişim adresi: https://ekitap.ktb.gov.tr/TR-194363/hakikidivani.html. Erişim tarihi: 15.03.2020.

Çakır, M. \& Koncu, H. (2012). Şairleri yetiştiren bir kaynak olarak mecmûa. E. N. İşli (Ed.), Eski Türk edebiyatı çalışmaları VII, mecmûa: Osmanlı edebiyatının kırkambarı içinde (s. 117134). İstanbul: Turkuaz Yay.

Çavuşoğlu, M. \& Tanyeri, M. A. (1981). Hayretî divanı. İstanbul: İstanbul Üniversitesi Edebiyat Fakültesi Yay.

Çelebi, A. H. (2015). Eşrefoğlu divanı. Ankara: Hece Yay.

Ekinci, R. (2013). Hâfiz Hüseyin Ayvansarâyî. Vefâyât-ı Ayvansarâyî. İstanbul: Buhara Yay.

Ergun, S. N. (1936). Âşık Paşa. Türk şairleri, (C. 1, s. 129-144). İstanbul: Bozkurt Matbaası.

Erünsal, İ. E. (2006). Murad Molla Kütüphanesi. Türkiye diyanet vakfi İslam ansiklopedisi (C. 31, s. 188). İstanbul: TDV Yayın Matbaacılık ve Ticaret İşletmesi.

Gölpınarlı, A. (1932). Kaygusuz Vizeli Alâaddin. İstanbul: Remzi Kitaphanesi.

Gölpınarlı, A. (1936). Âşık Paşa'nın şiirleri. Türkiyat Mecmuası, 5, s. 87-100. Erişim adresi: https://b-ok.asia/book/3510960/1d3362. Erişim tarihi: 24.02.2020

Gürbüz, M. (2012). Şiir mecmuaları üzerine bir tasnif denemesi. E. N. İşli (Ed.), Eski Türk edebiyatı çalş̧maları VII, mecmûa: Osmanlı edebiyatının kırkambarı içinde (s. 97-113). İstanbul: Turkuaz Yayınları.

İsen, M. (1990). Usûlî divanı. Ankara: Akçağ Yay.

Karaman, N. N. (2002). Cemâlî divanı. İstanbul: Kitabevi.

Kaya, B. A. (2012). Usûlî. Türkiye diyanet vakfi İslam ansiklopedisi (C. 1, s. 213-214). İstanbul: TDV Yayın Matbaacılık ve Ticaret İşletmesi.

SEFAD, 2020; (44): 213-250 
Kılıç, A. (2012). Şiir mecmualarının tasnifine dair. E. N. İşli (Ed.), Eski Türk edebiyatı çalısmaları VII, mecmûa: Osmanlı edebiyatının kırkambarı içinde (s. 75-96). İstanbul: Turkuaz Yay.

Köksal, M. F. (2012). Metin neşrinin ana esasları. Türklük Bilimi Araştırmalar Dergisi, 31, 179209. Erişim adresi: https://dergipark.org.tr/tr/pub/tubar/issue/16972/177348. Erişim Tarihi: 15.03.2020.

Köksal, M. F. (2012a). Şiir mecmûalarının önemi ve mecmûaların sistematik tasnifi projesi (MESTAP). E. N. İşli (Ed.), Eski Türk edebiyatı çalışmaları VII, mecmûa: Osmanlı edebiyatının kırkambarı içinde (s. 409-431). İstanbul: Turkuaz Yay.

Köksal, M. F. (2017). Dinî-tasavvufî Türk musikîsi araştırmalarında ihmal edilen bir yazma türü: ilâhî mecmuaları ve mühim bir ilâhi mecmuası. Ş. Özdemir \& A. Gün (Ed.), Geçmişten Günümüze Uluslararası Dinî Mûsikî Sempozyumu içinde (s. 331-336). Ankara: Kibatek.

Kurnaz, C. (1998). Hayâlî Bey. Türkiye diyanet vakfı İslam ansiklopedisi (C. 17, s. 5-7). İstanbul: Divantaş.

Levend, A. S. (1984). Türk edebiyatı tarihi (C. 1). Ankara: Türk Tarih Kurumu Basımevi.

Özdil, H. (2014). 19. yüzyıl İstanbulu'nun ilim merkezlerinden Murad Molla Tekkesi ve Kütüphanesi. F. M. Emecen \& A. Akyıldız \& E. S. Gürkan (Ed.), Uluslararası Osmanlı İstanbulu sempozyumu II içinde (s. 609-636). İstanbul: İstanbul 29 Mayıs Üniversitesi Yay.

Pekolcay, A. N. \& Uçman, A. (1995). Eşrefoğlu Rûmî. Türkiye diyanet vakfı İslam ansiklopedisi (C. 11, s. 480-482). İstanbul: Divantaş.

Tatcı, M. (1998). Hayretî. Türkiye diyanet vakfı İslam ansiklopedisi, C. 17. İstanbul: Divantaş.

Tatcı, M. (2008). Yûnus Emre divanı II. İstanbul: H Yay.

Tayşi, M. S. (1993). Cemâl-i Halvetî. Türkiye diyanet vakfı İslam ansiklopedisi, C. 7. İstanbul: Türkiye Diyanet Vakfı Vakıf Yayınları İşletmesi.

Uzun, M. (2000). İbrâhim Tennûrî. Türkiye diyanet vakfı İslam ansiklopedisi, C. 21. İstanbul: Divantaş.

Uzun, M. (2003). Mecmûa. Türkiye diyanet vakfı İslâm ansiklopedisi (C. 28, 265-268). Ankara: TDV Yayın Matbaacılık ve Ticaret İşletmesi.

Uzun, M.(1981). İlâhî. Türk dili ve edebiyatı ansiklopedisi devirler/ isimler/ eserler/ terimler, C. 4. İstanbul: Dergah Yay.

Yavuz, K. \& Yavuz, O. (2016). Muhibbî divanı. İstanbul: Türkiye Yazma Eserler Kurumu Başkanlı̆̆g. 